\title{
薬用植物及び単離培養地衣菌の二次代謝物の多様性
}

\author{
棚 橋 孝雄
}

\section{Diversity of Secondary Metabolites from Some Medicinal Plants and Cultivated Lichen Mycobionts}

\author{
Takao Tanahashi \\ Kobe Pharmaceutical University; 4-19-1 Motoyamakita-machi, Higashinada-ku, Kobe 658-8558, Japan.
}

(Received June 26, 2017)

\begin{abstract}
Studies on the structural determination, biosynthesis, and biological activities of secondary metabolites from natural sources are significant in the field of natural products chemistry. This review focuses on diverse secondary metabolites isolated from medicinal plants and cultivated mycobionts of lichens in our laboratory. Monoterpene-tetrahydroisoquinoline glycosides and alkaloids isolated from Cephaelis acuminata and Alangium lamarckii gave important information on the biosynthesis of ipecac alkaloids. A variety of glycosides linked with a secologanin unit and indole alkaloids were obtained from medicinal plants belonging to the families of Rubiaceae, Apocynaceae, and Loganiaceae. Plant species of the four genera Fraxinus, Syringa, Jasminum, and Ligustrum of the family Oleaceae were chemically investigated to provide several types of secoiridoid and iridoid glucosides. The biosynthetic pathway leading from protopine to benzophenanthridine alkaloids in suspension cell cultures of Eschscholtzia californica was elucidated. The structures and biological activities of the bisbenzylisoquinoline alkaloids of Stephania cepharantha and Nelumbo nucifera were also investigated. In addition, the mycobionts of lichens were cultivated to afford various types of metabolites that differ from the lichen substances of intact lichens but are structurally similar to fungal metabolites. The biosynthetic origins of some metabolites were also studied. These findings suggest that cultures of lichen mycobionts could be sources of new bioactive compounds and good systems for investigating secondary metabolism in lichens.
\end{abstract}

Key words — secondary metabolite; medicinal plant; cultivated lichen mycobiont; structure determination; biosynthesis; biological acitivity

\section{1. はじめに}

京都大学薬学部を卒業後, 引き続き京都大学大学 院薬学研究科に進学し, 恩師井上博之先生の主宰す る薬用植物化学講座で天然物化学の基礎を学び研究 の道に進んだ。その後, ドイツ・ミュンヘン大学 M. H. Zenk 教授の下での留学を経て, 神戸女子薬 科大学（当時, 現神戸薬科大学）の永倉直敬教授の 研究室のスタッフとなり, 以後, 天然物化学の分野 で研究を行ってきた。 三教授は，かねてよりイリド イド，アルカロイドの生合成研究で緊密な協力関係 にあり, 必然的に筆者も関連分野の研究を継続発展 させることとなった。 その後, 地衣成分研究の大家

神戸薬科大学（T658-8558 神戸市東灘区本山北町 419-1)

e-mail: tanahash@ kobepharma-u.ac.jp

本総説は, 平成 27 年度退職にあたり在職中の業績を中 心に記述されたものである.
である故 S. Huneck 教授とドイツのハレにおける 出会いと交流を通して触発を受け, 単離培養地衣菌 の代謝物の研究にも精力を注ぐようになつた。 それ 以外にも, 高等植物が生産するフラボノイドやキサ ントン, クマリンなどのフェノール性化合物, テル ペノイド類の構造や活性に関する研究にも取り組ん だが，本稿ではセコイリドイド，アルカロイド，及 び単離地衣菌の代謝物の研究成果について述べる.

2. セコイリドイド配糖体及び関連化合物に関す る研究

置換シクロペンタン環を持つモノテルペンである イリドイドのシクロペンタン環が開裂した一連の化 合物はセコイリドイドと称される. $\left.{ }^{1}\right)$ イリドイド, セコイリドイドは双子葉植物にかなり広く分布して おり, その大部分は配糖体として存在している. 1960 年代初頭より構造解明が開始され，セコイリ ドイドがインドールアルカロイドの非トリプタミン 


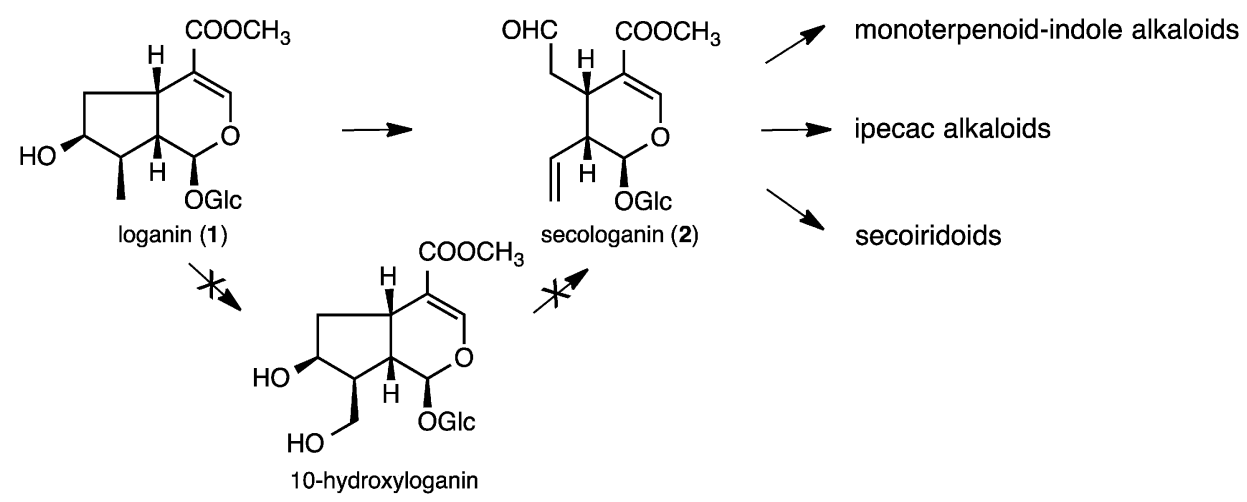

Fig. 1. Biosynthetic Pathway from Loganin to Secologanin, a Key Intermediate for Monoterpenoid-Indole Alkaloids, Ipecac Alkaloids, and Secoiridoids

部の起源に関連していることから, 生合成研究も活 発に行われた. インドールアルカロイドや, トコン アルカロイドは，イリドイド配糖体 loganin（1）の シクロペンタン環が開裂して生じた secologanin (2) がトリプタミンあるいはドーパミンと結合後, 脱グ ルコシル化し，さらに種々の反応を経て生成するこ とが明らかとなっている.

Battersby は loganin（1）より生成する 10hydroxyloganin の 10-phosphate よりリン酸基が脱 離する際に, シクロペンタン環が協奏的に開裂して secologanin（2）が生成するという機構を提出し

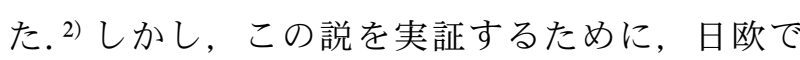
競つて 10-hydroxyloganin を合成し，その投与実験 が行われたが，この魅力的な説は否定されるに至つ た. ${ }^{3,4)}$ 後年, Inoue らが, シトクロム P-450 酸化酵 素によるシクロペンタン環の開裂により，1 から 2 が直接生成することを明らかにし，ようやくこの問

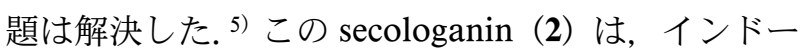
ルアルカロイドやトコンアルカロイドのみならず, 多様なセコイリドイドの前駆物質として重要性が認 識されていた (Fig. 1).11) そこで, secologanin (2) に関連する化合物について，その生合成に関心を払 いつつ, 種々の植物の成分検索に取り組むことにし た.

2-1. テトラヒドロイソキノリンーモノテルペン 配糖体及び関連化合物 トコン及び Alangium lamarckii におけるトコンアルカロイドの生合成研 究は, Battersby ら 6 ,7) や Nagakura, Zenk ${ }^{8,9)}$ によつ て行われ, secologanin (2) と dopamine の PictetSpengler 縮合により生成する $N$-deacetylisoipecoside（3）（ $S$ 体）及び $N$-deacetylipecoside（4）（R
体）のうち，3 が emetine（5), cephaeline（6）な どトコンアルカロイドの生合成中間体であることの 証明がなされた。一方，4は ipecoside（7）あるい は alangiside（8）など含窒素配糖体に代謝される ことが示された. すなわち，これらはともにその生 合成過程で立体配置は保持されることが明らかと なっている (Fig. 2)。しかし, $N$-deacetylisoipecoside（3）がトコンアルカロイドの前駆体であるこ とは証明されたが，実際に植物体から $S$ 体の配糖 体が単離された例はなく，また 3 からトコンアルカ ロイドへの詳細な生合成経路についても検討されて いなかった，そこで，生合成中間体など重要な示唆 を与える化合物の単離を目指して，トコンアルカロ イド含有植物の成分検索を行った.

植物界で, benzo [a] quinolizine 骨格を有するト コンアルカロイドの分布は極めて限られており, ア カネ科 Cephaelis ipecacuanha, Psychotria granadensis, ウリノキ科 Alangium lamarckii, クロタキ カズラ科 Cassinopsis ilicifolia など数種が知られて いるのみであった。筆者らは日本薬局方収載のトコ ン及び数種のウリノキ科植物の含窒素配糖体及びア ルカロイド成分を主な研究対象とし，各種スペクト ル解析と化学的手法により構造決定した.

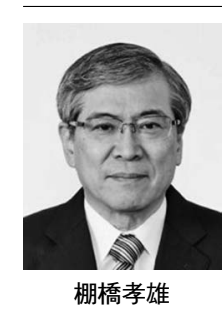

1981 年京都大学大学院薬学研究科博士 課程修了。ドイツ・ミュンヘン大学博 士研究員を経て，1984 年神戸女子薬科 大学講師, 助教授, 2001 年より神戸薬 科大学教授. 2005-2007 年副学長. 2007-2013 年神戸薬科大学学長. 2016 年定年退職. 神戸薬科大学特別教授 · 名誉教授. 2014-2017 年日本地衣学会 会長. 

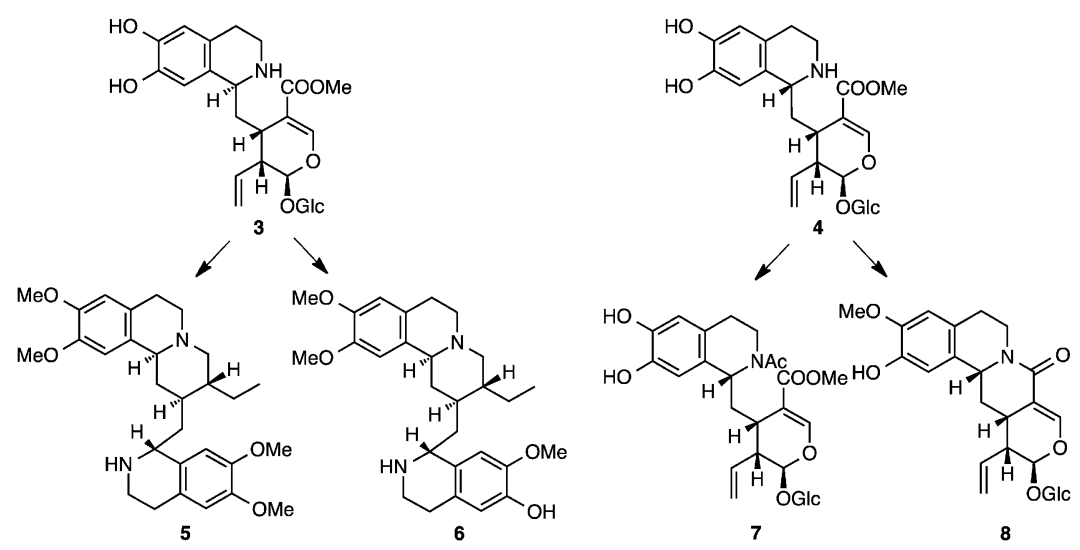

Fig. 2. Schematic Representation of the Biosynthetic Pathway of Ipecac Alkaloids and Related Alkaloidal Glucosides

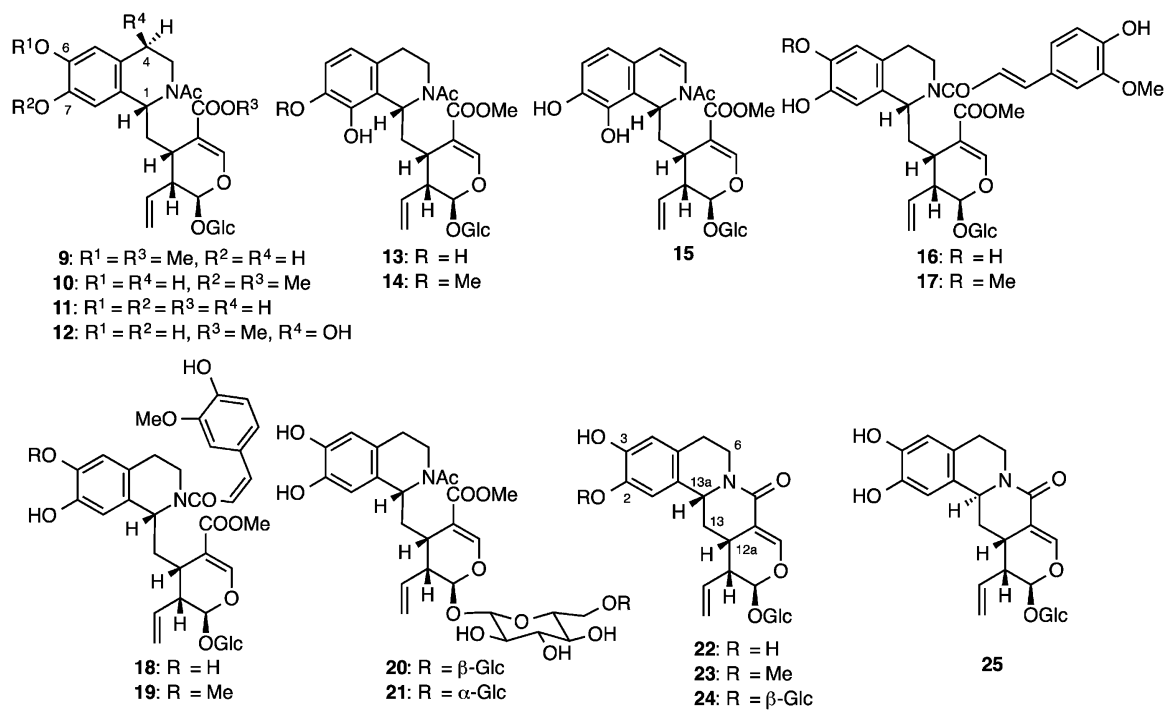

Fig. 3. New Tetrahydroisoquinoline-Monoterpene Glycosides 9-25 from Cephaelis acuminata

2-1-1. トコンの含窒素配糖体 ${ }^{10-14) \quad ト コ ン ~}$ (吐根) はブラジル原産のアカネ科植物 Cephaelis ipecacuanha A. RICHARDの根部で，日本薬局方に 収載されている重要な生薬である。本生薬は強い催 吐作用を有し，催吐薬，去痰薬として用いられてい る。トコンのアルカロイドとしては emetine (5) や cephaeline（6）などが知られているが, 配糖体 成分については ipecoside（7）が報告されているの みであった. トコンアルカロイドの薬理活性につい ては，催吐，鎮咳，去痰作用に加えて，抗アメーバ 活性，抗腫瘍活性，タンパク合成阻害活性など多く の報告がある.

市場品の生薬トコン（日本薬局方に従い, 当初は 筆者らもC. ipecacuanha の種名を用いていたが, 国立衛試の佐竹元吉先生の指摘により, $C$. acuminata KARSTEN と改めた. ${ }^{15)}$ 日本薬局方の初版 から第 12 改正版までは基原を C. ipecacuanha とし ていたが，第 13 改正以降 C. acuminata が追加され た）を植物材料として用いた．生薬トコンから多量 の ipecoside（7）とともに，既知配糖体 sweroside, ketologanin, alangiside（8）及び 17 種の新規含窒 素配糖体 9-25 が得られた（Fig. 3).

配糖体の含量は主成分の ipecoside (7) についで, 6-O-methylipecoside（9）が多く, 7-O-methylipecoside（10）も極少量得られたが，7の 6,7- ジメチル 体は得られなかつた。

興味深い化合物として, neoipecoside（13）と7$O$-methylneoipecoside (14), 3,4-dehydroneoipecoside（15）を単離した. Neoipecoside（13）は，芳 香環の置換様式が異なる ipecoside (7) の異性体で, 


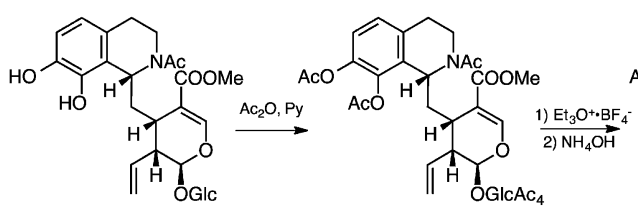

13

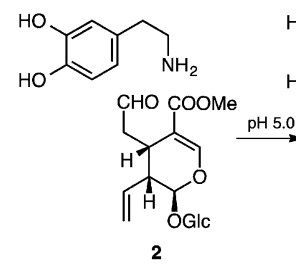

2
26

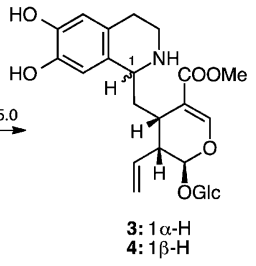

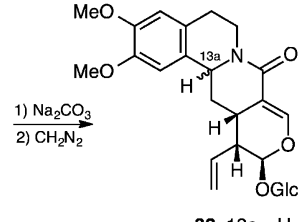

32: $13 \mathrm{a} \alpha-\mathrm{H}$
33: $13 \mathrm{a} \beta-\mathrm{H}$

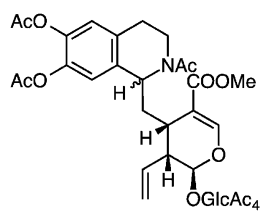

30: $1 \alpha-H$

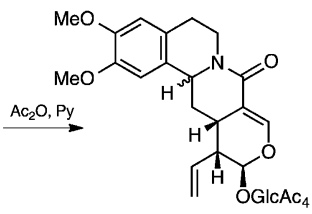

28: $13 \mathrm{a} \alpha-\mathrm{H}$

Fig. 4. Preparation of Compounds 27-31 for Determination of the Absolute Configuration of Neoipecoside (13)

neoipecoside hexaacetate (26) の NOE 実験により, 7,8-dihydroxy 体と決定した. Neoipecoside（13） のC-1 位の絶対配置は, 26 をラクタム 27 に変換し, $\mathbf{2 7}$ と化合物 28-31 を比較することにより決定し た. 化合物 28-31 については, 既に立体化学と NMR スペクトルの関連が報告されていたからであ る. ${ }^{16)}$ Secologanin (2) と dopamine を弱酸性条件 下で縮合させると C-1 位の立体異性体 $N$-deacetylisoipecoside (3) と $N$-deacetylipecoside (4) が生じる，3，4 を弱アルカリ性でラクタム化，つい でメチル化して C-13a 位立体異性体 methylisoalangiside (32) と methylalangiside (33) (ipecoside 骨 格の C-1 は alangiside 骨格では C-13a に対応）と し，アセチル化することにより $\mathbf{2 8}$ と 29 が得られる. 3 と 4 のアセテート 30 と 31 及び 29 の ${ }^{1} \mathrm{H}-\mathrm{NMR}$ ス ペクトルでは，アセチル基のシグナルは正常な化学 シフトで観測される。一方，28ではアセチル基の シグナルの 1 つが大きく高磁場シフトする.これは, $13 \mathrm{a} S$ 配置を持つ 28 では, グルコースがベンゼン環 の上に近接する立体配座をとるため, ベンゼン環の 遮蔽効果があるためと説明される。また化合物 $\mathbf{2 8}$ と 29 では H-13 と H-13a 間の結合定数が大きく異 なることが報告されている．化合物 $\mathbf{2 7}$ ではアセチ ル基が高磁場シフトしていないことと, 結合定数の 解析より $R$ 体と決定した。 また 27 と 28,29 の CD スペクトルの比較からも $R$ 体であることが支持さ れ, neoipecoside（13）のC-1 位の絶対配置は $R$ と 決定した (Fig. 4).

trans-Cephaeloside（16） 及び cis-cephaeloside （18）は ipecoside（7）の N-アセチル基が $N$-transフェルロイル基あるいは $N$-cis-フェルロイル基に置
換した配糖体である。また 17 と 19 は，16 と 18 の 6 位ヒドロキシ基がメチル化された化合物と決定し た。また alangiside ( 8 ) や新規化合物 demethylalangiside (22) 及び 3-O-demethyl-2-O-methylalangiside（23）などラクタム環を持つ化合物も得 られた.

高極性の水溶性画分からは, 11, 12, 20, 21, 24 が 得られた。 さらに, Alangium lamarckii から 13aS 配置のアランギサイド型配糖体を単離した後ではあ るが, 本植物材料からも $13 \mathrm{a} S$ 配置を有する demethylisoalangiside (25) を単離することができた.

2-1-2. ウリノキ科植物の含窒素配糖体及び関連 化合物 ${ }^{17-22)}$ ウリノキ科の Alangium lamarckii THWAITES はインド及び東南アジアに自生する灌木 で，インド地方では民間薬として用いられている. アルカロイド成分の報告は多くあるが，配糖体成分 に関しては loganic acid と alangiside（8）が報告さ れているのみであった。 そこで, A. lamarckii の乾 燥果実の成分検索を行い, 23 とともに新規含窒素 配糖体 32-56 とイリドイド配糖体 57 を単離, 構造 決定した（Fig. 5).

配糖体 32 は ${ }^{1} \mathrm{H}-\mathrm{NMR}$ スペクトルから methylalangiside（33）の可能性が考えられたが, 33 の ${ }^{1} \mathrm{H}-\mathrm{NMR}$ スペクトルと比較すると，13 位メ于 レン水素と $13 \mathrm{a}$ 位メチン水素の結合定数に大きな差 が認められた．さらに， ${ }^{13} \mathrm{C}-\mathrm{NMR}$ スペクトルにお いても， 33 と比較すると， 6, 12a，13 位炭素シグナ ルのケミカルシフトに顕著な差があることから，配 糖体 32 は 13a 位に関する立体異性体である methylisoalangiside の可能性が考えられた。そこ で，天然物 32 及びそのアセテートを, secologanin 


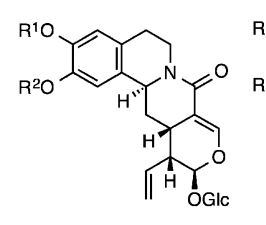

$$
\begin{aligned}
& \text { 32: } R^{1}=R^{2}=M e \\
& \text { 34: } R^{1}=M e, R^{2}=H \\
& \text { 35: } R^{1}=H, R^{2}=M e
\end{aligned}
$$

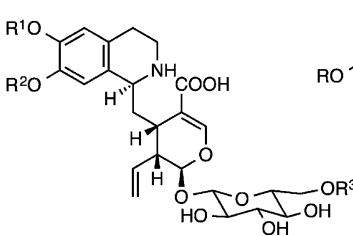

36: $R^{1}=R^{2}=M e, R^{3}=H$

37: $R^{1}=M e, R^{2}=R^{3}=H$
38: $R^{1}=R^{3}=H, R^{2}=M e$

39: $R^{1}=M e, R^{2}=H, R^{3}=\alpha-G l c$

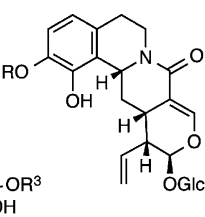

40: $R=H$
41: $R=M e$

35: $R^{1}=H, R^{2}=M$

(1)

\section{.}

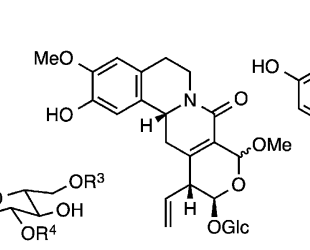

49: $R^{1}=M e, R^{2}=R^{4}=H, R^{3}=\beta-G l c$

51: $\mathrm{R}^{1}=\mathrm{Me}, \mathrm{R}^{2}=\mathrm{R}^{4}=\mathrm{H}, \mathrm{R}^{3}=\alpha-\mathrm{G}$

52: $R^{1}=R^{4}=H, R^{2}=M e, R^{3}=\alpha-G l c$
53: $R^{1}=M e, R^{2}=R^{4}=H, R^{3}=\alpha-X y l$

54: $\alpha$-OMe
55: $\beta$-OMe
36: $R^{1}=R^{2}=M e, R^{3}=H$
37: $R^{1}=M e, R^{2}=R^{3}=H$

50: $R^{1}=M e, R^{2}=R^{3}=H, R^{4}=\beta$-Glc

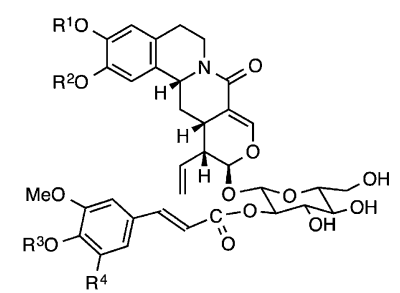

42: $R^{1}=R^{2}=R^{3}=R^{4}=H$

43: $R^{1}=M e, R^{2}=R^{3}=R^{4}=H$

44: $R^{1}=R^{3}=R^{4}=H, R^{2}=M e$

45: $R^{1}=R^{2}=R^{3}=H, R^{4}=O M e$

46: $R^{1}=M e, R^{2}=R^{3}=H, R^{4}=O M e$

48: $R^{1}=\mathrm{Me}, \mathrm{R}^{2}=\mathrm{R}^{4}=\mathrm{H}, \mathrm{R}^{3}=\mathrm{CH}\left(\mathrm{CH}_{2} \mathrm{OH}\right)_{2}$

Fig. 5. New Tetrahydroisoquinoline-Monoterpene and Related Glycosides 32-57 from Alangium lamarckii

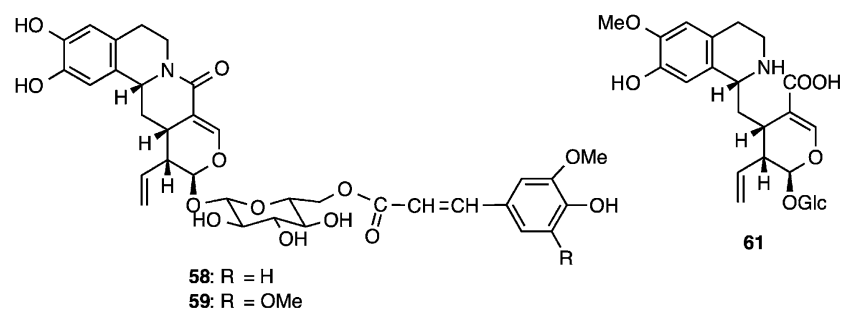

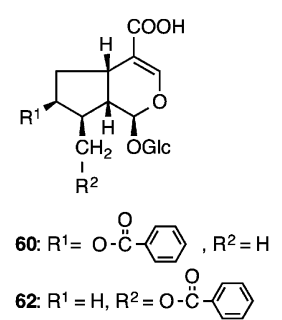

Fig. 6. New Tetrahydroisoquinoline-Monoterpene and Related Glucosides 58-62 from Alangium spp.

から誘導した標品と直接比較することにより, 32 を methylisoalangiside と同定した。また, isoalangiside (34), 3-O-demethyl-2-O-methylisoalangiside （35）やカルボン酸 36-39 も得られ，トコンアルカ ロイドの生合成中間体 $\mathbf{3}$ と同じ $S$ 配置を有する配 糖体を, 天然物として初めて単離することができた。

Demethylneoalangiside（40） 及び neoalangiside （41）は，トコンから単離した 13，14 と同様，芳香 環の置換様式が通常と異なる化合物である。さら に，アランギサイド型配糖体のグルコース部がアシ ル化した 42-48，もう一分子の糖が結合した 49-53 が得られた。 また，2-メトキシジヒドロピラン環を 持つ配糖体 54, 55 及び 10-hydroxyvincoside lactam (56)， 6'- $\alpha$-D-glucopyranosylloganic acid（57）を単 離した. A. lamarckii では, tubulosineなどテトラ ヒドロ- $\beta$-カルボリン骨格を持つアルカロイドが知 られているが, secologanin と縮合して生じる含窒 素配糖体にはこの骨格の配糖体の例はなく, 56 が
単離されたことは興味深い.

さらに, 他のウリノキ科植物の葉部の成分検索を 行つた (Fig. 6).A. platanifolium var. trilobum の 葉部からは demethylalangiside（22）とともに新規 配糖体 58-60 が得られた. ${ }^{23,24)}$ A. kurzii からは 8 , 22 ともに 6-O-methyl- $N$-deacetylipecosidic acid （61）と62 を単離した. ${ }^{25)}$ A. chinense からは, 含 窒素配糖体としては 22 が得られたのみであった. ${ }^{26)}$ Demethylalangiside（22）は Alangium 属植物に共 通の配糖体と考えられる。

\section{2-1-3. トコン及び Alangium lamarckii のアルカ} ロイドトコンからは既知のトコンアルカロイ ド27) emetine (5), cephaeline (6), psychotrine (63), protoemetine (64), 9-demethylprotoemetinol (65), isocephaeline（66）とともに新規ア ルカロイド neocephaeline (67), 7'-O-demethylcephaeline (68), 10-O-demethylcephaeline (69), $2^{\prime}-N$ - ( $1^{\prime \prime}$-deoxy-1" $-\beta$-D-fructopyranosyl) cephaeline 


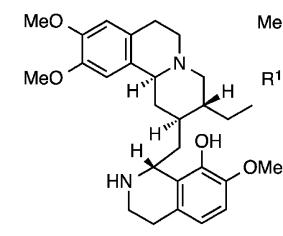

67

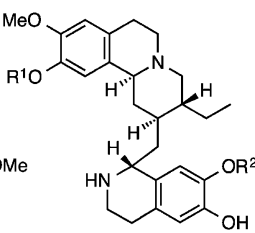

68: $R^{1}=M e, R^{2}=H$
69: $R^{1}=H, R^{2}=M e$

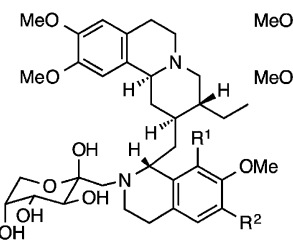

70: $\mathrm{R}^{1}=\mathrm{H}, \mathrm{R}^{2}=\mathrm{OH}$ 70: $R^{1}=H, R^{2}=O H$
$R^{1}=O H, R^{2}=H$

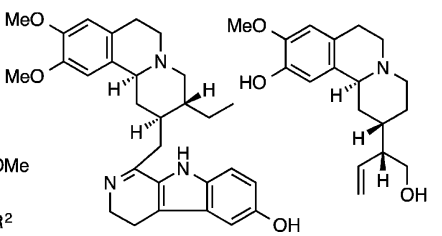

76

Fig. 7. New Ipecac Alkaloids 67-71, 76 and 77 from Cephaelis acuminata and Alangium lamarckii

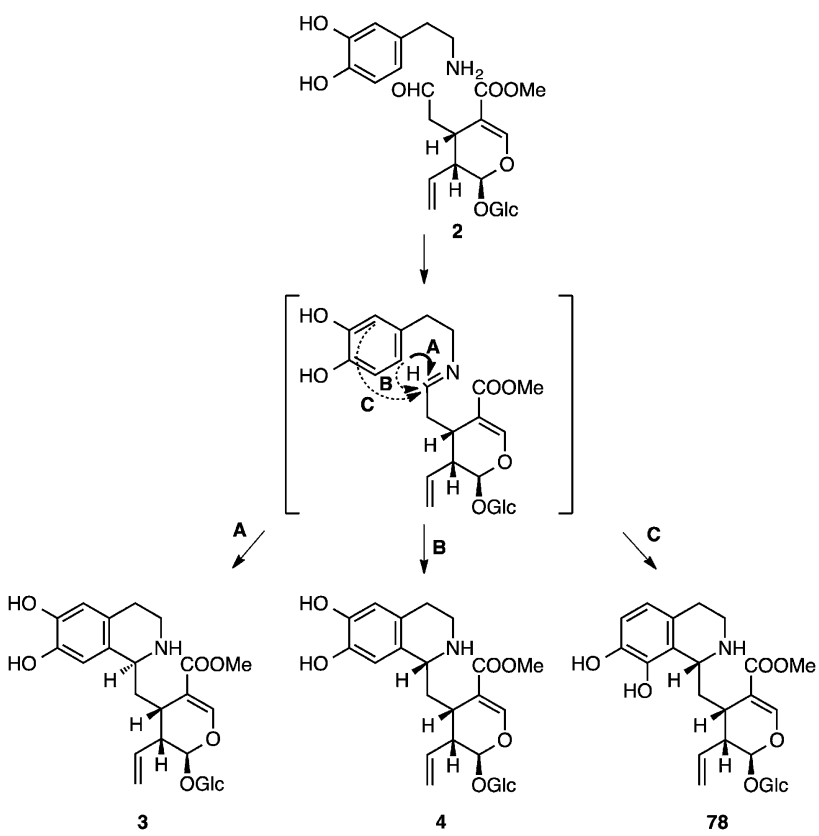

Fig. 8. Condensation of Secologanin with Dopamine in Cephaelis acuminata and Alangium lamarckii

(70), $2^{\prime}-N$ - (1" -deoxy-1"- $\beta$-D-fructopyranosyl) neocephaeline（71）を得た（Fig. 7).15) そのうち neocephaeline（67）は，ベンゼン環（E 環）の酸素官 能基の置換様式が従来のトコンアルカロイドと異な るものである. 68 と 69 は，6のメトキシ基 1 つが ヒドロキシ基に置き換わつたもので，生合成的に興 味深い。また 70 と 71 は $N$ - (1-deoxy-1- $\beta$-D-fructopyranosyl）基を持つユニークなものである. 両化 合物は, 6 あるいは 67 と D-glucose を酢酸とトリエ チルアミン中加熱することにより得られることか ら，抽出過程でトコンアルカロイドから Amadori 転位により生じるアーティファクトの可能性も考え られる。しかし, emetine（5）から生じると予想さ れる化合物は，合成的には得られたが，本植物材料 からは検出されなかった.

A. lamarckii の乾燥果実からは, 既知アルカロイ ドの 6, 63, 64, 66, deoxytubulosine (72), tubulo- sine (73), isotubulosine (74), protoemetinol (75), salsoline に加えて，トコンから新規化合物として単 離した 67, 69, 70 が得られた。また，新規化合物と して $1^{\prime}, 2^{\prime}$-dehydrotubulosine (76) と alangine (77) を構造決定した（Fig. 7). ${ }^{28)}$ Alangine（77）は新規 骨格を持つアルカロイドである.

\section{2-1-4. 生合成経路の考察 A. lamarckiiより} methylisoalangiside（32）など $S$ 配置を持つ配糖体 を単離することにより，トコンアルカロイド生合成 の想定中間体 $\mathbf{3}$ の存在が間接的に証明できた。 さら に置換様式の異なる 40 を単離したことから, dopamine と secologanin の縮合において，3 種類の 閉環機構が植物内に存在することが示唆された。す なわち，中間体となるイミンが A の方向に閉環す れば 3 が，B の方向に閉環すれば 4 が，C の方向に 閉環すれば $N$-deacetylneoipecoside（78）が生成す ると考えられる（Fig. 8)，そこで，De-Eknamkul， 


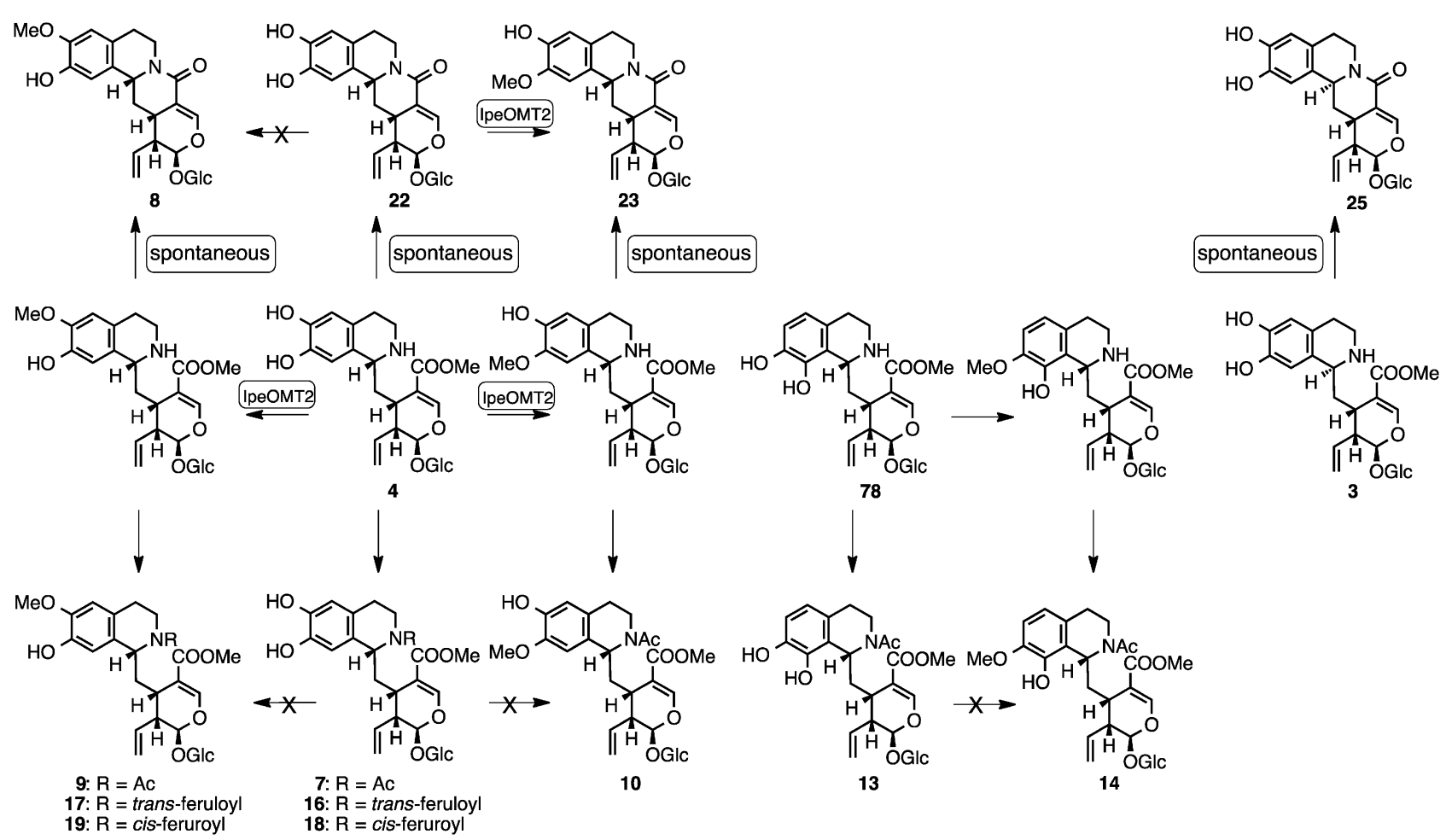

Fig. 9. Possible Biosynthetic Pathway of Tetrahydroisoquinoline-Monoterpene Glucosides in Cephaelis acuminata

Kutchan, Zenk らと協力して，A. lamarckii の葉部 の無細胞抽出液より, dopamine と secologanin か ら 3 及び 4 を生成する 2 種の縮合酵素を発見し た. ${ }^{29)}$ しかし，78へ変換する酵素活性は見い出せな かった。 De-Eknamkul らは，引き続き酵素の精製 に取り組み, deacetylisoipecoside synthase について は不安定なため精製はできなかったが, deacetylipecoside synthase を精製し，この酵素が dopamine と secologanin から立体特異的に 4 を生成すること を明らかにした。 ${ }^{30}$

最近，Kutchan らは Psychotria ipecacuanha $(=C$. ipecacuanha $)$ の培養細胞より $\beta$-D-glucosidase 及び $O$-methyltransferase $の$ cDNA をクローニ ングし，リコンビナントタンパク質を用いて，トコ ンアルカロイドの生合成に係わる $\beta$-D-glucosidase IpeGlu1 と 3 種の $O$-methyltransferase IpeOMT1, IpeOMT2, IpeOMT3 の機能を論じている. ${ }^{31,32)}$ その 知見を考慮にいれ，われわれの研究室で得られた化 合物の生合成経路を考察する.

トコンでは，9，10, 17, 19 などの $N$-アシル化配糖 体は， $N$-deacetylipecoside（4）のメチル化，アシ ル化により生合成され，その順序が問題となるが, メチル化酵素の基質特異性から, ${ }^{32}$ ipecoside（7）
や cephaeloside 類 16, 18 などのメチル化は起こら ず，4 の 6 位あるいは 7 位のメチル化が先行して起 こり，その後にアシル化が起こると考えられる．ア ランギサイド型配糖体 8, 22, 23 は，4 やそのメチ ル体のラクタム化により生じる.このラクタム化反 応は容易に起こり，非酵素的反応と考えられるが,

23 は 22 のメチル化酵素によるメチル化によっても 生じる可能性がある. ${ }^{32)}$ トコンの成分検索では 6,7dimethylipecoside や methylalangiside の存在を確認 できなかつたが，想定される両化合物の前駆物質を いずれのメチル化酵素もメチル化しないという報告 とよく符合している. ${ }^{32)} \mathbf{7 8}$ も同様にして, メチル 化，アセチル化反応により 13 と 14 を与える， 3 は アシル化を受けず，大部分はトコンアルカロイドへ 至る生合成経路にのり，一部が非酵素的なラクタム 化により 25 を生成したと考えられる（Fig. 9).

A. lamarckii では， $N$-アシル化配糖体は認められ ず，ラクタム化した配糖体が得られた。 トコンの場 合と同様にメチル化，非酵素的なラク夕ム化により,

4 から 8, 22, 23 を生成し, 78 からは 40,41 を生じ る。 3 からは, 4 の場合と異なり, dimethyl 体 32 が生成するが，これはメチル化酵素の基質特異性に 基づいていると考えられる. ${ }^{32)}$ トコンでは 2 種のメ 


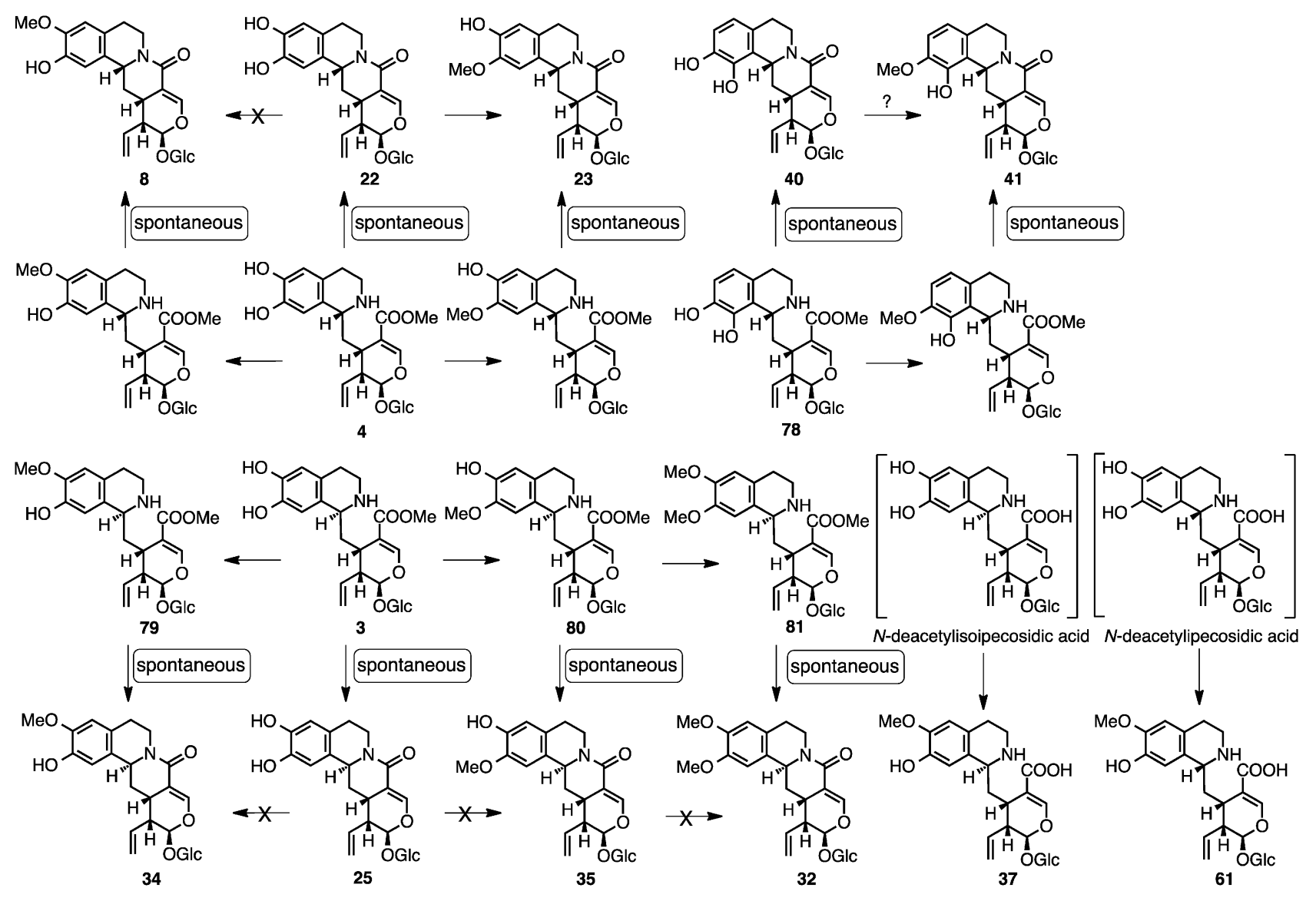

Fig. 10. Possible Biosynthetic Pathway of Tetrahydroisoquinoline-Monoterpene Glucosides in Alangium lamarckii

チル化酵素の組み合わせにより $N$-deacetylisoipecoside（3）から，79 と 80,81 が生成することが明ら かにされている．植物種が異なるが，A. lamarckii においても同様に，3 がメチル化後，ラクタム化が 進行して，25，32，34，35 が生じると考えられる．配 糖体 37 や A. kurzii の 61 は, カルボン酸誘導体で あるため容易にラクタム化しない。これらは，Ndeacetylisoipecosidic acid 又は $N$-deacetylipecosidic acid のメチル化によって生成する。 $N$-deacetylisoipecosidic acid 及び $N$-deacetylipecosidic acid は, 3 及び 4 の脱メチル化，あるいは secologanin（2) のデメチル体 secologanic acid と dopamine の縮合 により生合成される可能性が考えられる(Fig. 10).

トコンアルカロイドの cephaeline (6), emetine （5）は3から protoemetine（64）を経て生合成され るが，3 から 64 へ至るには，メチル化と脱グルコ シル化が起こる必要がある。. A lamarckii から 34, 35, 32 を単離したことから, トコンアルカロイド生 合成において第 1 のイソキノリン骨格のフェノール 性ヒドロキシ基のメチル化は配糖体の段階で起こる
ことが示唆された．Kutchan らにより，3 379 は グルコシダーゼ IpeGlu1 の基質となるが， 80, 81 は 有効な基質ではないこと，また 3 種のメチル化酵素 の基質特異性から，3 が 6 位のメチル化を受けて 79 へ変換された後に，脱グルコシル化によりアグリコ ンを与え，アグリコンがイミニウムカチオンの形 成，還元，メチルエステルの加水分解と脱炭酸，エ ノールのアルデヒド基への異性化などの過程と，メ チル化酥素 IpeOMT3 によるメチル化を経て 64 が 生成する機構が示された. ${ }^{31,32)}$ Protoemetine（64) のアルデヒド基は第二の dopamine との縮合反応に 供される。この縮合反応には, secologanin と dopamine の場合と同様に，3 種の機構が想定され る。その生成物の 1 つである 68 をトコンから単離 した。これはメチル化酵素 IpeOMT2 によって特異 的に $7^{\prime}$ 位がメチル化され 6 となり，さらに IpeOMT1 により 5 を与えることが確認されてい る. ${ }^{32)}$ 他の 2 種の縮合反応生成物は単離されていな いが，それぞれがメチル化酵素によってメチル化を 受け neocephaeline（67）と isocephaeline（66）が 


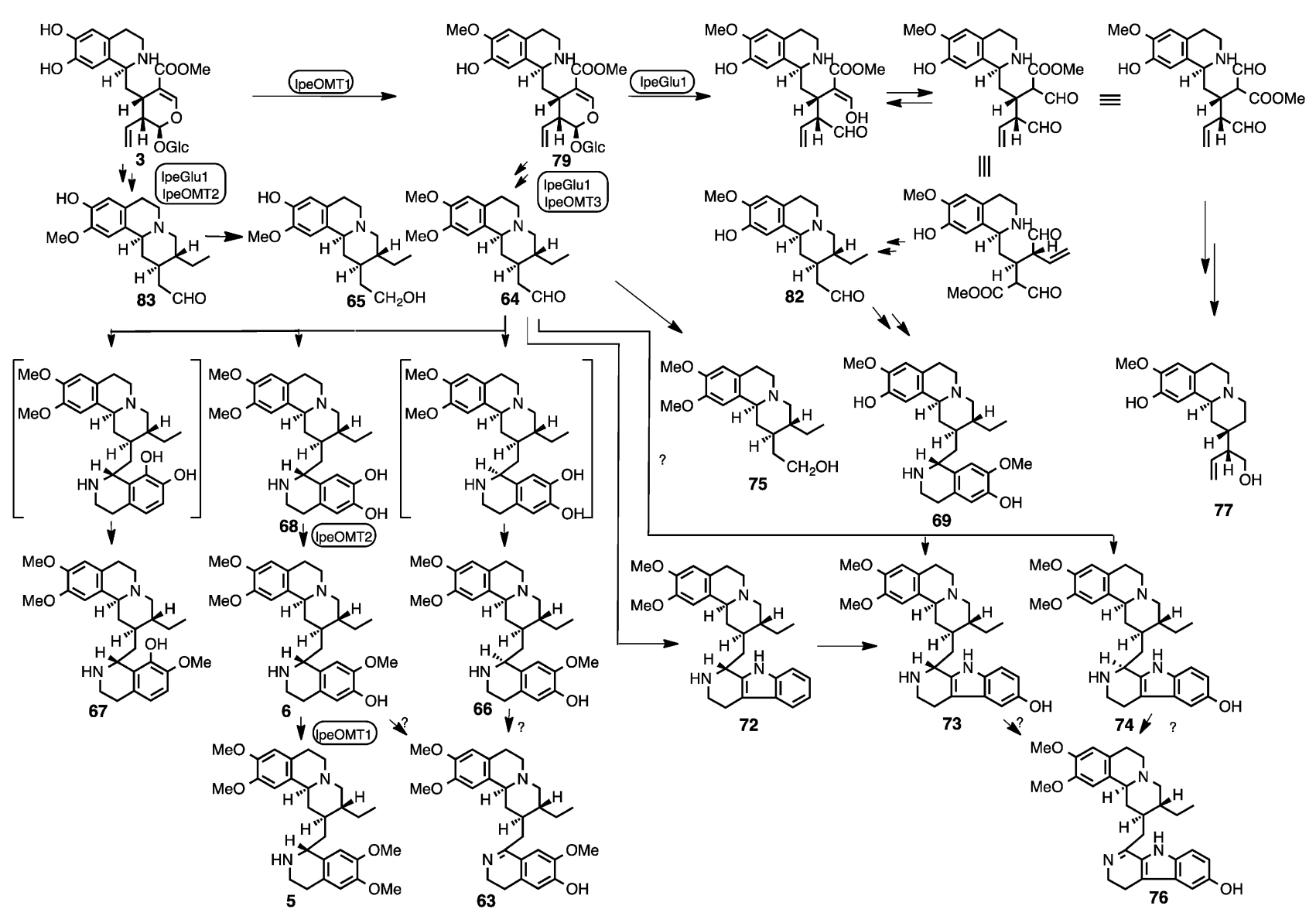

Fig. 11. Possible Biosynthetic Pathway of Alkaloids in Cephaelis acuminata and Alangium lamarckii

生じると説明できる.しかし， 6 と 66 はエピマー であり，両者のデヒドロ体に相当する psychotrine (63) が共存することから， $(S)$-reticuline から 1, 2dehydroreticulinium ion を経て, $(R)$-reticuline へ の変換にみられるような, ${ }^{33)}$ 酸化-水素化の機構に より 6 から 63 を経て 66 を生じる可能性も否定はで きないが，最近，A. lamarckii における投与実験で 6 が 63 へ変換されなかったことから，6から 63 へ の $1^{\prime}, 2^{\prime}$ 位の脱水素は起こらないとする報告があ

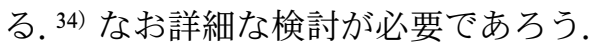

79 の脱グルコシル化後に, メチル化を受けなけ れば 82 となり， 3 が脱グルコシル化後に， IpeOMT2 によるメチル化を受けると 83 を生じ る. ${ }^{32)} 82$ が第二の dopamine との縮合反応，メチル 化により 69 が生成し，一方，83 の還元により 65 が生成すると考えられる（Fig. 11）。

A. lamarckii におけるトコンアルカロイド生合成 経路はトコンと同様に考えられるが，64 が dopamineではなく, tryptamine と縮合すると $\beta$-カルボ リン骨格を持つ 72 が生成し，72 のヒドロキシ化に
より tubulosine（73）が生成する。 Isotubulosine （74）は，64 と dopamine の縮合によって生じた 72 のエピマーがヒドロキシ化を受けるか，あるいは 64 が serotonine と縮合することにより生成する可 能性が考えられる。しかし，73,74とともに $1^{\prime}$, 2'-dehydrotubulosine（76）を単離したことから,

一方のエピマーのみが生成し，デヒドロ体を中間体 とする酸化-水素化反応が起こる可能性も排除はで きない.

Alangine（77）は新規骨格を有するアルカロイド である、79から脱グルコシル化により生じるアグ リコンのアミノ基が，82 の場合とは異なるアルデ ヒド基との間でイミニウムカチオンを形成し，還 元, メチルエステルの加水分解と脱炭酸, アルデヒ ド基の還元を経て，77 が生成すると考えられる (Fig. 11).

最近, 分子生物学的手法により, トコンアルカロ イドの生合成に大きな進展がみられるが， N-deacetylneoipecoside（78）の合成酵素, protoemetine (64) と第二の dopamine あるいは tryptamine との 


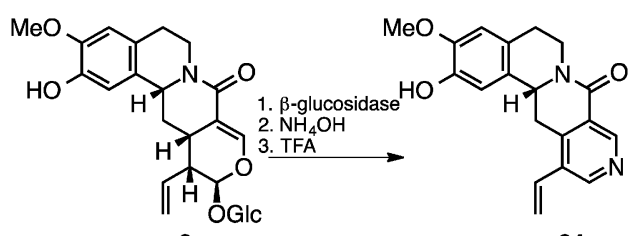

84

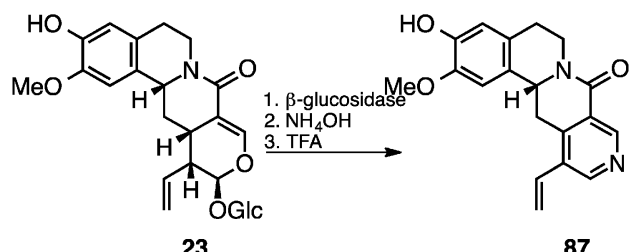

87

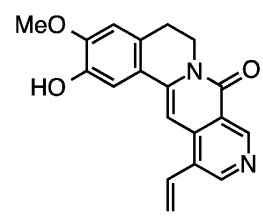

85

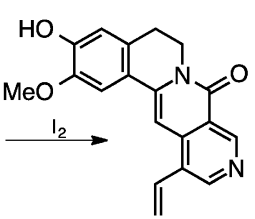

86

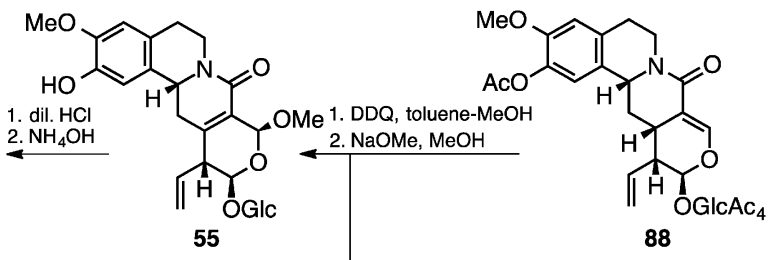

$+$

Fig. 12. Chemical Conversion of Tetrahydroisoquinoline-Monoterpene Glucosides into Benzopyridoquinolizine Alkaloids

縮合反応を触媒する酵素，また protoemetine（64） や alangine（77）の詳細な生成機構などは，今後に 残された興味深い課題である.

2-1-5. Alangimaridine, isoalangimarine 及 alangimarine への化学変換 Alangimaridine (84) は alangimarine（85）や isoalangimarine（86）とと もに benzo $[a]$ pyrido $[3,4-g]$ quinolizine 骨格を持つ ユニークな A. lamarckii のアルカロイドである. Pakrashi らは 84 の C-13a 位の絶対配置は，旋光度 の符号から $R$ 配置と予想し, 6-O-methyl- $N$-deacetylipecoside からの推定生合成経路を提案していた. ${ }^{35)}$ しかし，84 の推定立体配置はトコンアルカロイド $\mathbf{5}$ や 6 とは異なっていることから，84 の立体配置を 確定しておくことが必要と考えた。 そこで，8 から 84 を，23 から 86 の前駆体に相当する $(+)$ isoalangimaridine (87) へ生合成仮説を模倣した変 換を試みた。 Alangiside（8) を $\beta$-glucosidase で加 水分解後, アンモニア，ついで TFA で処理すると (+)-alangimaridine が得られたことから，Pakrashi らの予想通り 84 の C-13a 位は $R$ 配置であることを 明らかにした。 また同様にして，23 から 87 に変換 し，さらに酸化して 86 が得られた（Fig. 12). ${ }^{36)}$

一方，前述のように A. lamarckii から配糖体 54, 55 を単離した。これらは alangiside pentaacetate （88）を DDQ で酸化後, 脱アセチル化することに より得られるが，また $\mathbf{8}$ をメタノール中で長期間放 置することによっても得られた。したがって，54 と 55 は, 抽出過程で 8 の酸化と $\mathrm{MeOH}$ の付加に より生じたアーティファクトと考えられる。 また, 55 を希塩酸，ついでアンモニアで処理することに
より，85 が得られた。この事実から，これらアル カロイドが天然物である可能性は否定できないもの の，少なくとも部分的には非酵素的に生成している ことが考えられる (Fig. 12). ${ }^{21)}$

2-1-6. モノテルペノイドーインドールアルカロイ ド含有植物の配糖体とアルカロイド モノテルペ ノイドーインドールアルカロイド含有植物の含窒素 配糖体についても関心を持ち，成分検索を行った。 インドールアルカロイドは強い生物活性から医薬品 として重要なものも多く, tryptamine と secologanin から Pictet-Spengler 反応により生成する strictosidine（89）を経て生合成されることが明らかに されている. 含窒素配糖体として 89 のほか, strictosidinic acid $(90),(5 S)$-5-carboxy-strictosidine (91), vincosamide (92), strictosamide $(\mathbf{9 3}), 3 \alpha$ dihydrocadambine（94）などが知られている（Fig. 13).

アカネ科 (Rubiaceae)，キョウチクトウ科 (Apocynaceae)，マチン科 (Loganiaceae) 植物に モノテルペノイドーインドールアルカロイドが多く 含まれていることから，含窒素配糖体あるいは secologanin 由来の配糖体を予想して，アカネ科の Neonauclea sessilifolia, Adina racemosa, Uncaria setiloba, マチン科の Strychnos spinosa, S. axillaris の成分検索を行った，種々の成分を単離したが，セ コイリドイド配糖体及び関連化合物についてのみ記 述する (Fig. 14)。

N. sessilifolia からは, strictosidine のアミノ基に もう 1 分子の secologanin が縮合した neonaucleoside A (95) や, neonaucleoside B (96) とC (97) 


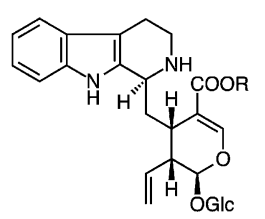

89: $R=M e$
90: $R=H$

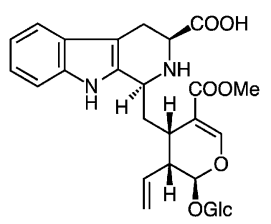

91

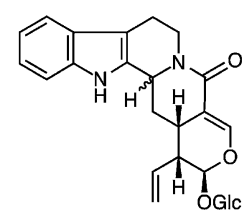

92: $\beta-H$

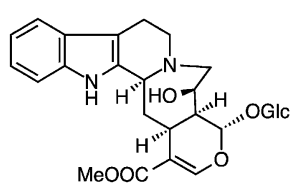

94

Fig. 13. Representative Tetrahydro- $\beta$-carboline-Monoterpene Glucosides

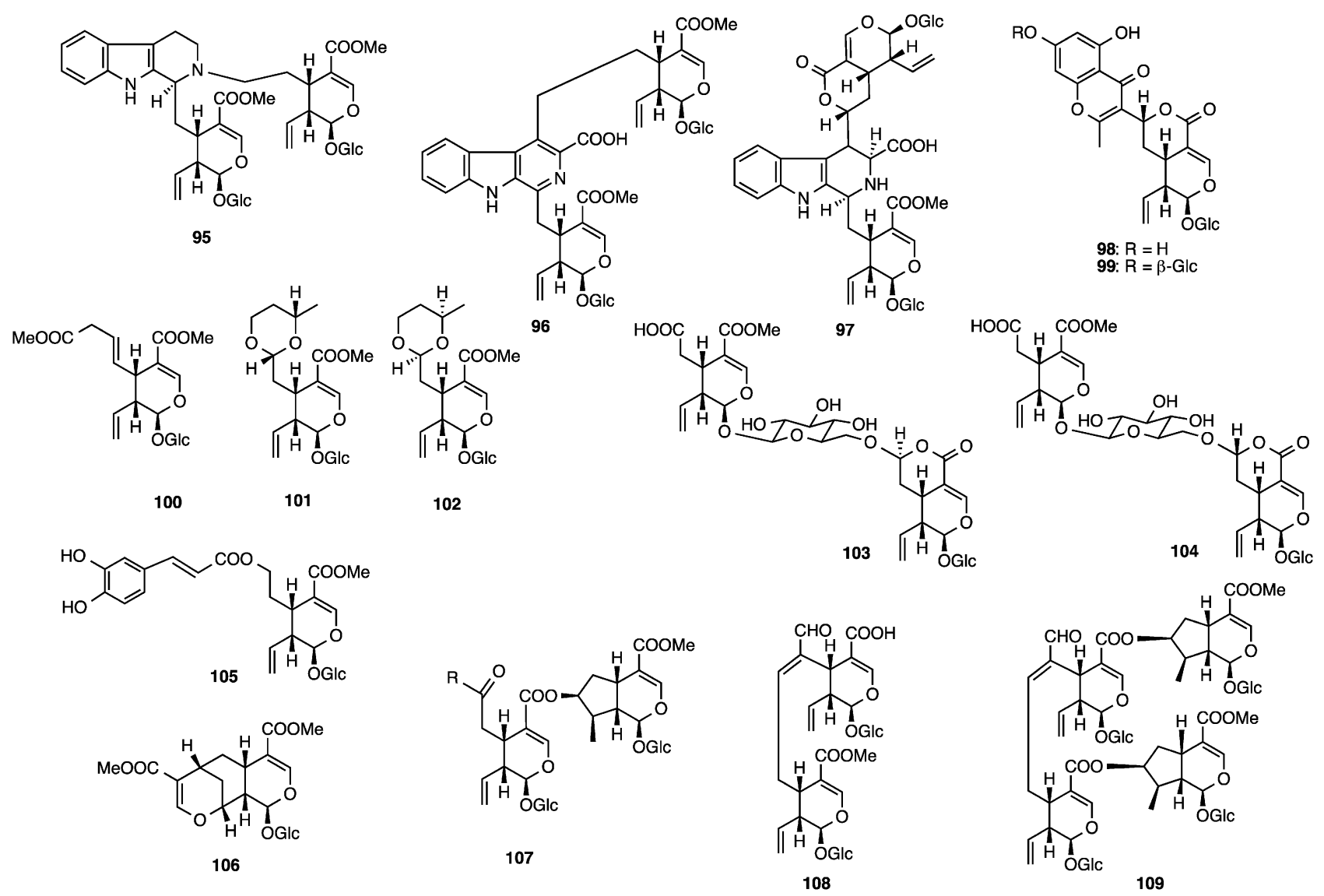

Fig. 14. New Glucosides 95-109 Isolated from Neonauclea sessilifolia, Adina racemosa, Strychnos spinosa, and Strychnos axillaris

が得られた。またクマリン骨格を持つ特異な構造の 化合物 sessilifoside (98) と99が得られた. ${ }^{37)} \mathbf{9 8}$ と 99 は, secologanin が酶酸-マロン酸経路の $\mathrm{C}_{10}$ ポリ ケチド鎖とアルドール型縮合することにより生合成 されると考えられる.A. racemosa からは既知物質 として92,93 及び secologanin とその誘導体が得ら れたほか，新規配糖体 adinoside A-E（100-104） と grandifloroside 11-methyl ester（105）を単離し た. ${ }^{38)}$ また，U. setiloba からは含窒素配糖体は単離 されず，既知オキシインドールアルカロイドが同定 された. ${ }^{39)}$ S. axillaris からは90が，S. spinosaから は91が単離されたが，新規含窒素配糖体は得られ
なかつた．新規セコイリドイド配糖体として， $S$. spinosa からは stryspinoside（106）, 及び strychoside A (107) と B (108), ${ }^{40)}$ S. axillaris からは axillaroside（109）を単離，構造決定した。 ${ }^{41)} 106$ はユ ニークな構造を持つ化合物で, secologanin とマロ ン酸由来の $\mathrm{C}_{3}$ ユニットから生合成されると考えら れる. 類似の架橋構造を持つ化合物は secologanin より tandem-Knoevenagel-hetero-Diels-Alder 反応に よって化学的に合成されている. ${ }^{42)}$

これら植物では, secologanin（2）は tryptamine と縮合反応をするだけではなく, secologanin が持 つアルデヒド基, 活性メチレン基またビニル基など 


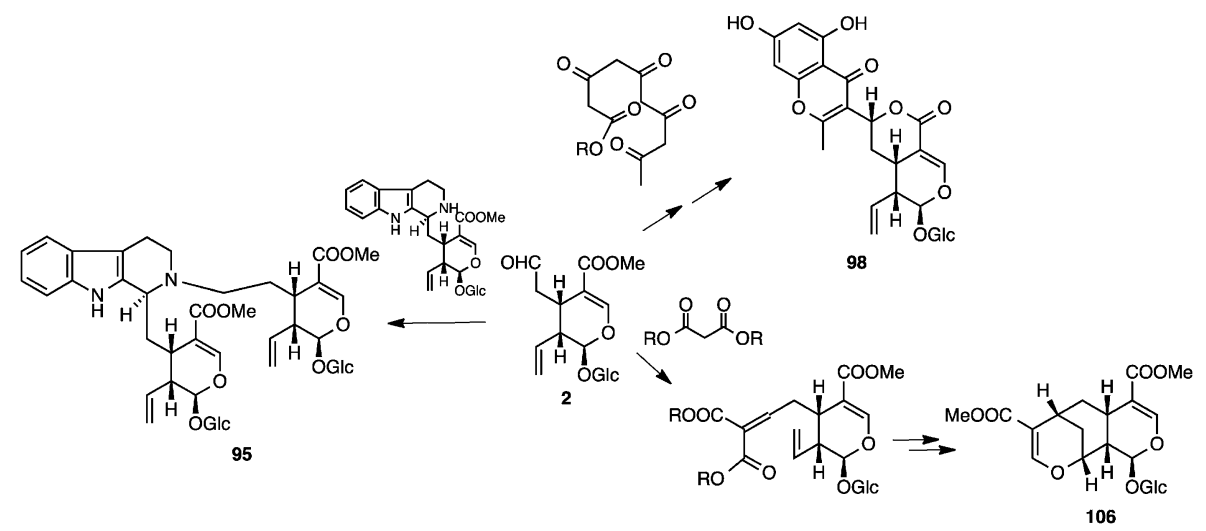

Fig. 15. Possible Biogenetic Formation of Diverse Glucosides from Secologanin

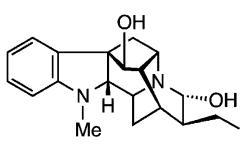

110

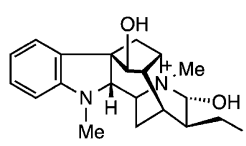

112

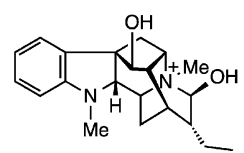

$113^{*}$

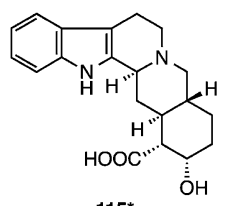

115

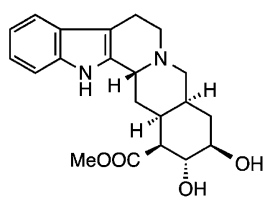

119

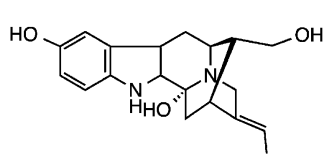

$114^{*}$

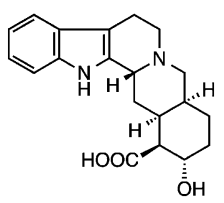

$116^{*}$

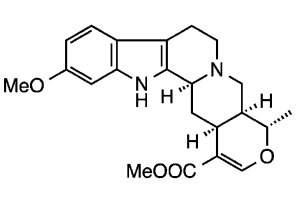

120

Fig. 16. Indole Alkaloids Isolated from Rauwolfia serpentina Asterisks indicate new compounds.

の官能基により，種々の化合物と縮合し，多様な化 合物を生成することが明らかとなった（Fig. 15).

キョウチクトウ科のインドジャボク Rauwolfia serpentina の乾燥根には, 抗不整脈作用のある ajmaline（110）や，降圧作用のある reserpine（111） など多くのアルカロイドが知られている. インドジャ ボクからは含窒素配糖体は検出できなかったが，イ リドイド配糖体 loganic acid, 7-deoxyloganic acid, secoxyloganin, 7-epiloganin と多くのアルカロイド を得た。また新規アルカロイド $N_{\mathrm{b}}$-methylajmaline (112), $N_{\mathrm{b}}$-methylisoajmaline (113), 3-hydroxysarpagine (114), yohimbinic acid (115), isorauhimbinic acid（116）を単離し，構造決定を行った。さら に, アルカロイド 115, 116 と, 既知アルカロイド のうち reserpine (111), yohimbine (117), isorau- himbine (118), 18-hydroxyepialloyohimbine (119), methyl reserpinine (120) について DNA トポイソ メラーゼ阻害活性を評価した。 115, 116 及び 111 が 強い阻害作用を示したが，それ以外のアルカロイド は阻害しなかった。115, 116 の topo I に対する $\mathrm{IC}_{50}$ はそれぞれ， $30 \mu \mathrm{M} ， 40 \mu \mathrm{M}$ であり，111の topo II に対する $\mathrm{IC}_{50}$ は $20 \mu \mathrm{M}$ であった。同条件下 で, camptothecin の topo I に対する $\mathrm{IC}_{50}$ は $20 \mu \mathrm{M}$, etoposide の topo II に対する $\mathrm{IC}_{50}$ は $40 \mu \mathrm{M}$ であっ たので, これらのアルカロイドは比較的強いトポイ ソメラーゼ阻害活性を示した (Fig. 16). ${ }^{43)}$

2-2. モクセイ科のセコイリドイド配糖体及び関 連化合物 モクセイ科植物は 25 属, 約 600 種か らなり, 薬用植物として用いられているものも多 い.オリーブ (Olea europaea) は食用として重要 


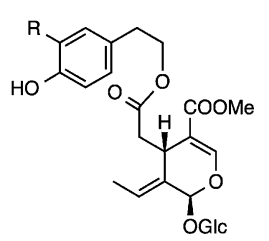

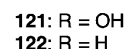

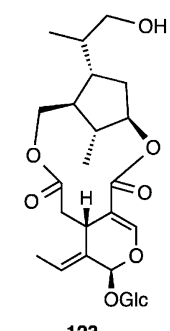

123

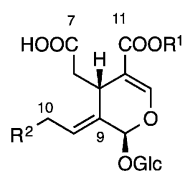

124: $R^{1}=R^{2}=H$

125: $R^{1}=M e, R^{2}=H$

126: $R^{1}=M e, R^{2}=O H$

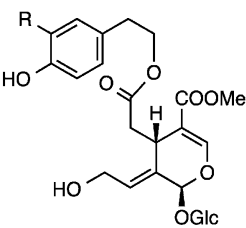

127: $\mathrm{R}=\mathrm{OH}$ 128: $R=H$

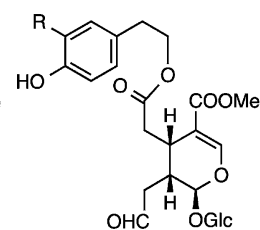

129: $\mathrm{R}=\mathrm{OH}$

Fig. 17. Representative Secoiridoid Glucosides of the Family Oleaceae<smiles>CC1C(C(=O)O)OCC1(C(=O)O)C(=O)O</smiles>

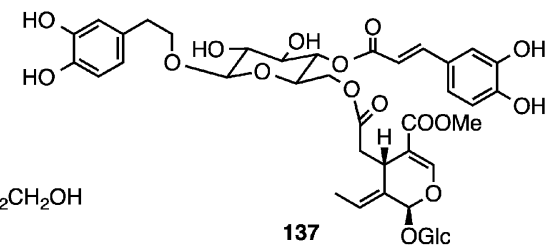

131: $\mathrm{R}^{1}=\mathrm{CH}_{2} \mathrm{CH}_{2}--\left(17-\mathrm{OH}, \mathrm{R}^{2}=-7\right.$

133: $\mathrm{R}^{1}=\mathrm{Me}, \mathrm{R}^{2}=--\left(7-\mathrm{CH}_{2} \mathrm{CH}_{2} \mathrm{OGIC}\right.$

134: $\mathrm{R}^{1}=\mathrm{CH}_{2} \mathrm{CH}_{2}-(-7)-\mathrm{OH}, \mathrm{R}^{2}=-(7)-\mathrm{CH}_{2} \mathrm{CH}_{2} \mathrm{OGIC}$

135: $\mathrm{R}^{1}=\mathrm{CH}_{2} \mathrm{CH}-\left(\mathrm{C},-\mathrm{OH}, \mathrm{R}^{2}=\mathrm{H}\right.$

136: $\mathrm{R}^{1}=\mathrm{R}^{2}=\mathrm{CH}_{2} \mathrm{CH}_{2}-(-\mathrm{T})-\mathrm{OH}$
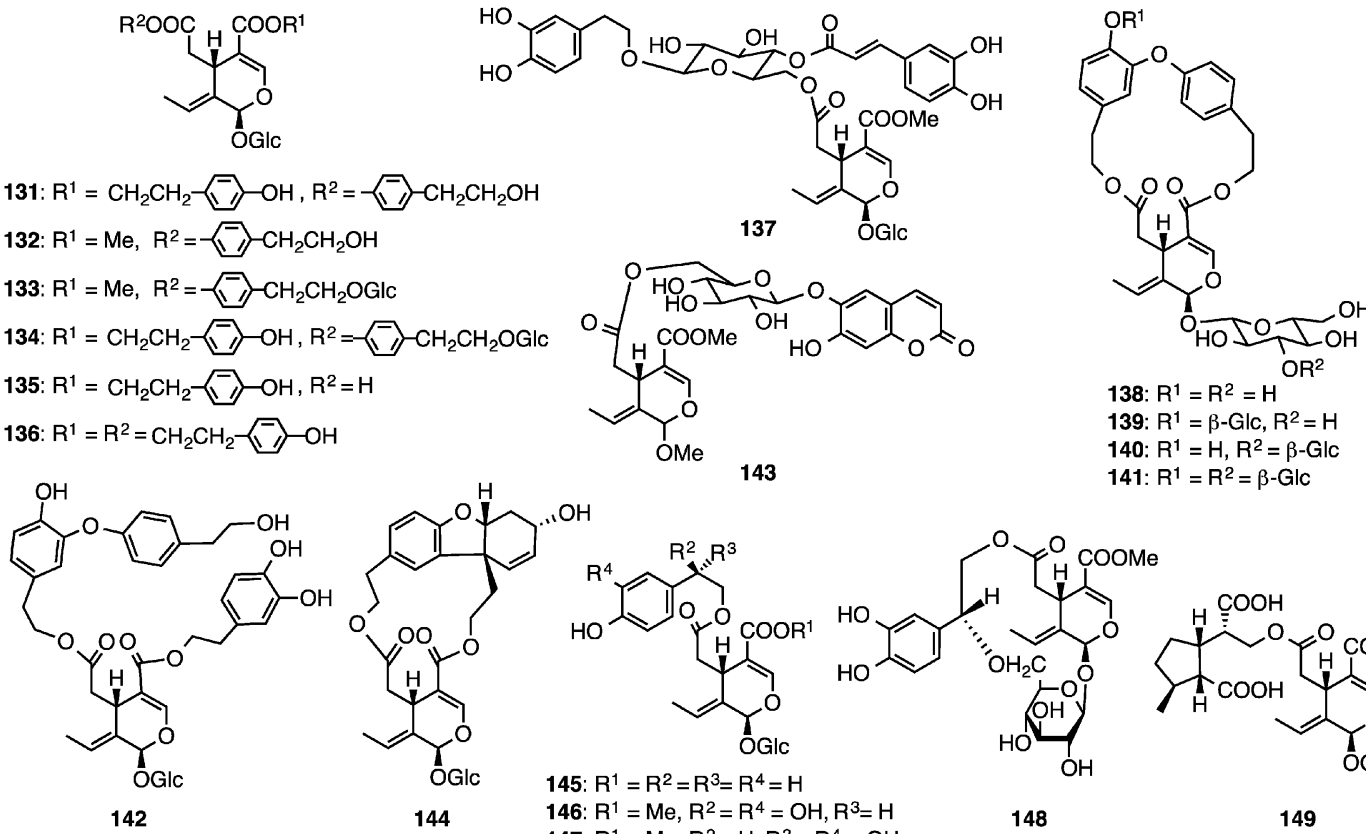

141: $R^{1}=R^{2}=\beta-G l c$

Fig. 18. New Secoiridoid Glucosides and Related Aglycones 131-149 Isolated from Fraxinus spp.

なばかりではなく, 降圧作用, 血糖降下作用など様 々な活性が注目されている。 また, 中医薬として, 抗炎症, 抗菌, 強壮の目的で用いられている秦皮 ( Fraxinus rhychophylla) がある。また女貞 (Ligustrum lucidum AIT.) の果実は伝統漢方薬で あり，肝腎を補う効能があるとされている。モクセ イ科植物にはイリドイド配糖体やセコイリドイド配 糖体が広く分布している. ${ }^{44)}$ 代表的なセコイリドイ ド配糖体として，オリーブの oleuropein（121）や ligstroside (122), ウンナンオウバイの jasminin (123) が知られており，これらは，7位がカルボキ シ基まで酸化され，9位にエチリデン基を持つ oleoside（124） あるいは oleoside 11-methyl ester （125）を基本骨格とする。また，10-hydroxyoleoside 11-methyl ester（126）を基本骨格とする 10- hydroxyoleuropein (127) や 10-hydroxyligstroside (128)，さらには 10 位にアルデヒド基を持つ ligustaloside A (129), B（130）がある（Fig. 17). これらの配糖体は，モクセイ科植物にのみ含まれて いる. モクセイ科植物のイリドイド及びセコイリド イド配糖体は, 構造的特徵が属によって異なること から，化学分類学上の重要な指標とされている．モ クセイ科植物 13 種の成分検索を行い, 多様な配糖 体の構造研究を行った.

2-2-1. トネリコ属 (Fraxinus) 植物のセコイリ

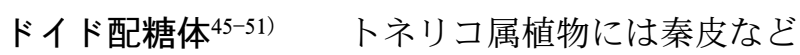
数種の生薬があり，これらの生薬では樹皮が薬用に 供されている。樹皮部にはクマリン配糖体が含まれ ている例は多い. しかし，トネリコ属植物の葉部に は 121 や122 などモクセイ科植物を代表するセコイ 


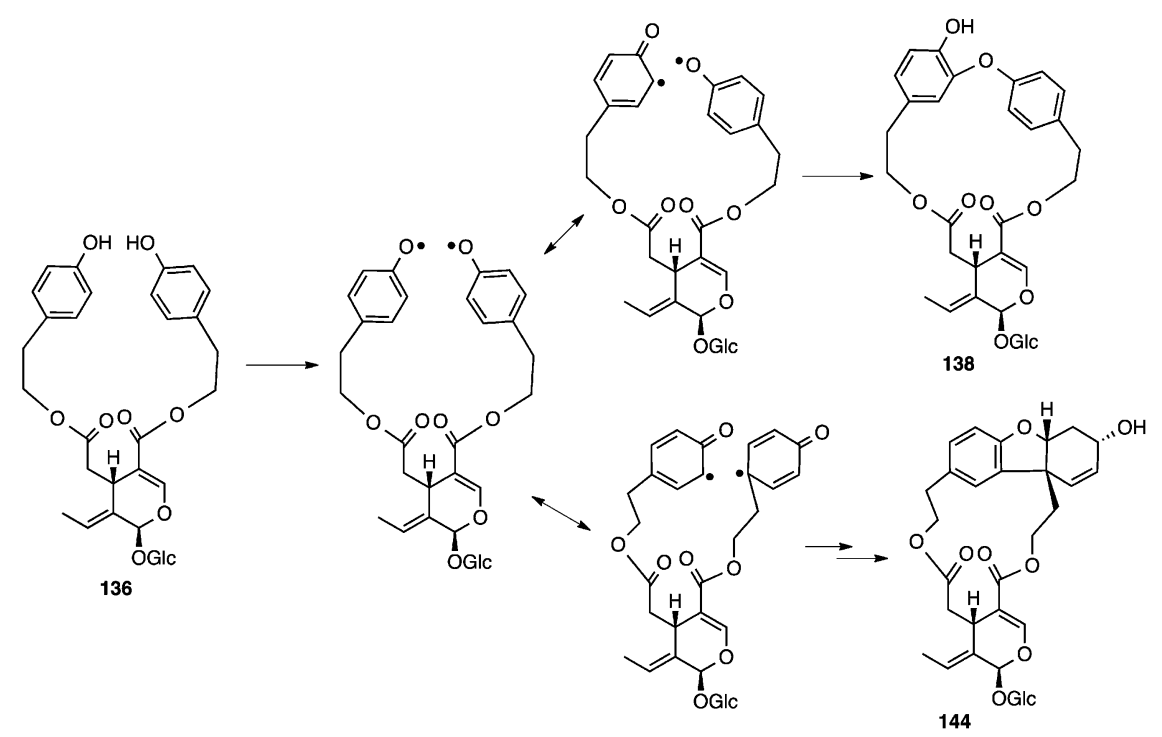

Fig. 19. Plausible Biogenetic Mechanism of the Formation of Glucosides $\mathbf{1 3 8}$ and $\mathbf{1 4 4}$ from $\mathbf{1 3 6}$

リドイド配糖体が報告されていた。 そこで，F. formosana, F. insularis, F. americana の葉部の成分検 索を行った。また，F. rhychophyllaに関しては, 果実を材料とした（Fig. 18）.

台湾産の F. formosana の葉部を検索すると, 新 規配糖体 131-136 が得られた. ${ }^{45,46)} F$. insularis から は 137-142, ${ }^{47-49)} F$. rhychophylla からは，クマリン とエステル結合した oleoside aglycone methyl ether の 143 とともに, ベンゾフラン誘導体と oleoside が結合した配糖体 144 が得られた. ${ }^{50)}$ 配糖体 131134 では 122 などと異なり，フェノール性ヒドロキ シ基が oleoside の 7 位のカルボキシル基とエステ ル結合していた．Inslaroside（138）では，ジフェ ニルエーテルとエステル結合しているという特徵が みられた。138 及び 144 は，framoside（136）の酸 化的フェノールカップリング反応によって生合成さ れると考えられる (Fig. 19)。 Framoside（136）の 2 分子の $p$-ヒドロキシフェニルエチルアルコール部 分からフェノキシラジカルが生じ，F. insularis で は分子内で C-O 結合して $\mathbf{1 3 8}$ となり, 一方 F. rhy chophylla では C-C 結合したのち閉環反応，還元反 応により 144 へと変換されると推定される.

F. americana からは配糖体 145-148 が得られた。 これらではフェニルエチルアルコール部のメチレン がヒドロキシ化されていた。 また，モノテルペン部

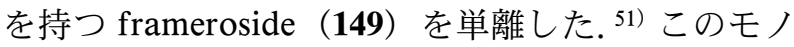
テルペン部のシクロペンタン環の絶対配置は geniposide（150）と化学的に関連づけることによ り決定した（Fig. 20)。 Geniposide（150）を文献記 載の方法により deoxyloganin（151）とし, 酵素で 加水分解すると deoxyloganin aglycone (152) が得 られる。これを PCC 酸化後, 153 をアルカリ条件 下， $\mathrm{NaBH}_{4}$ で還元を行うと 2 種の 4-epimer の混合 物 154 が得られた。 $(R)$-PGME と縮合後, 分離精 製して 2 種の（R)-PGME アミド 155 と 156 を得 た。両化合物のラクトン環の立体配座と C-4 の相 対配置は， ${ }^{1} \mathrm{H}-\mathrm{NMR}$ スペクトルにおける結合定数 の解析と NOE 相関より推定し，150 の C-5 位の絶 対配置は $R$ であることから，155 と 156 の C-4 の 絶対配置はそれぞれ $S$ と $R$ と決定した。アミド 155 と 156 の C-4 の絶対配置は， $(S)$-PGME アミ ド 157 と 158 の ${ }^{1} \mathrm{H}-\mathrm{NMR}$ の化学シフトとの比較か らも証明された。最終的に, frameroside（149）を アルカリ加水分解し，モノテルペン部を $(R)$ PGME アミドに誘導し，これが ${ }^{1} \mathrm{H}-\mathrm{NMR}$ 及び HPLC で 155 と一致したことから，149 由来のアミ ドの絶対配置は $4 S, 5 R, 8 S, 9 R$ であることが明らか となり, frameroside の絶対構造を決定した.

2-2-2. ハシドイ属 Syringa afghanica のセコイリ ドイド配糖体 Syringa afghanica からは新規化 合物 159-166 が得られた。ささらに 149 と類似の配糖 体 167 と 168 が得られた（Fig. 21）。 ${ }^{52)}$ 配糖体 167 は 149 の立体異性体と推定されたが，167 をメチル 化したところ，予想に反して 149 のメチル化生成物 


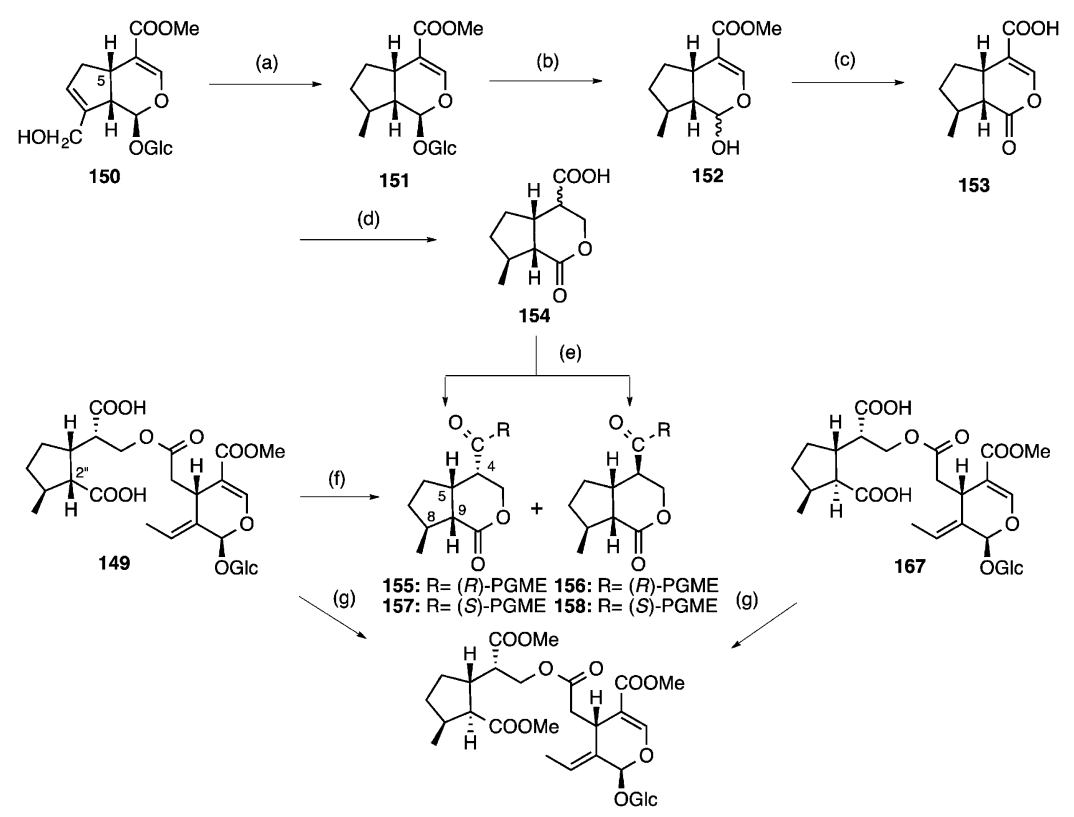

Fig. 20. Chemical Correlation of Secoiridoid Glucosides 149 and 167 with 150

Reagents: (a) (1) $\mathrm{Ac}_{2} \mathrm{O}$-pyridine, (2) $\mathrm{H}_{2}, \mathrm{Pd} / \mathrm{C}$, EtOH, (3) $0.1 \mathrm{M} \mathrm{NaOMe}, \mathrm{MeOH}$; (b) $\beta$-glucosidase, $\mathrm{H}_{2} \mathrm{O}$; (c) $\mathrm{PCC}_{2} \mathrm{CH}_{2} \mathrm{Cl}_{2}$; (d) (1) $\mathrm{NaBH}_{4}, 0.5 \mathrm{M} \mathrm{NaOH}$, (2) Amberlite IR-120; (e) $(R)$ - or $(S)$-PGME - HCl, PyBOP, HOBT, TEA, DMF; (f) (1) $0.5 \mathrm{~m} \mathrm{NaOH,} \mathrm{(2)} \mathrm{Amberlite} \mathrm{IR-120,} \mathrm{(3)}(R)$-PGME $\cdot \mathrm{HCl}$, PyBOP HOBT, TEA, DMF; (g) $\mathrm{CH}_{2} \mathrm{~N}_{2}, \mathrm{MeOH}$.

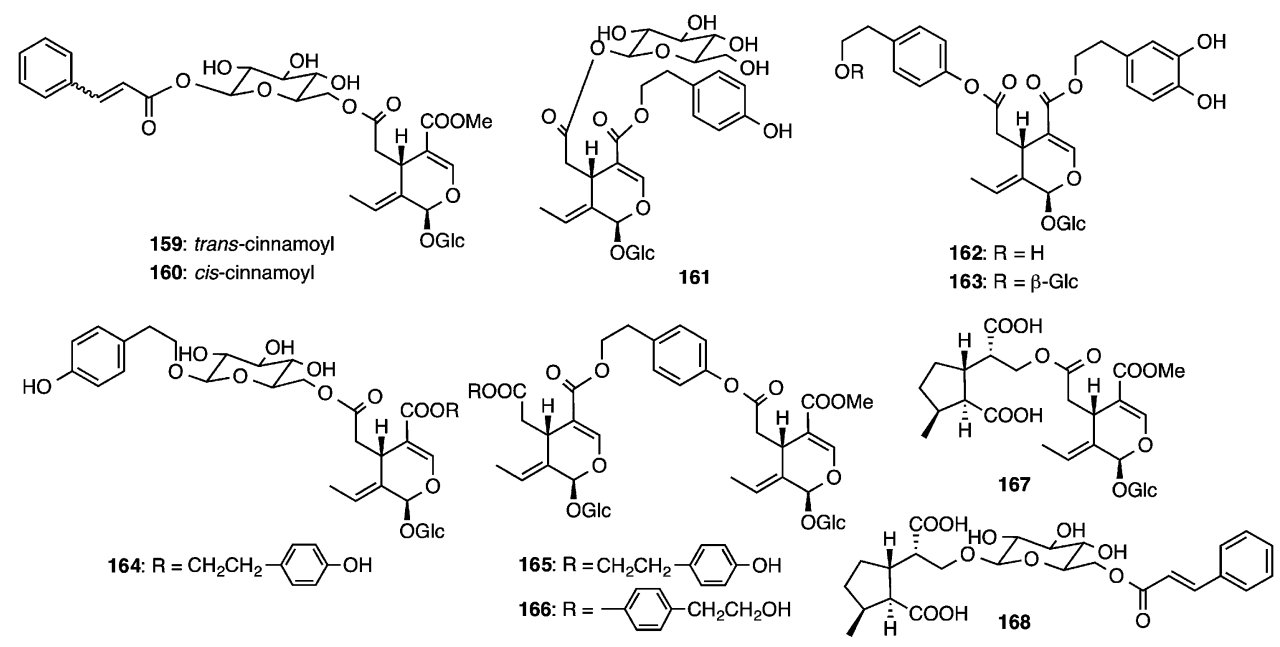

Fig. 21. New Secoiridoid Glucosides and Related Glucosides 159-168 from Syringa afghanica

と同一物が得られた（Fig. 20)。NMRスペクトル と NOESY 相関を検討することにより，149のメチ ルエステルでは C-2"でエピメリ化が起こることが 明らかとなり，配糖体 167 を" -epiframeroside と 決定した.

\section{2-2-3. ソケイ属（Jasminum）植物のセコイリ} ドイド配糖体 イボタノキ属, トネリコ属植物で は oleoside あるいは 10-hydroxyoleoside がフェニル エチルアルコール誘導体とエステル結合したセコイ リドイド配糖体が多く含まれるが，ソケイ属植物の
配糖体では様相が少し異なっている.J. officinale var. grandiflorum から得られた 169 と $\mathbf{1 7 0}$ では, フェニルエチルアルコール部分のメチレン基が酸素 化され，メトキシ基を有していた. ${ }^{53)} \mathrm{J}$. amplexicaule の 171-173 は，127 あるいは128 の 10 位ヒド ロキシ基に，さらに 10-hydroxyoleoside 11-methyl ester（126）がエステル結合した二量体や三量体で ある. ${ }^{54)}$ 一方, J. polyanthum では, 174 とともに, 122 あるいは 121 のフェノール性ヒドロキシ基ある いはグルコースのヒドロキシ基に oleoside 11- 


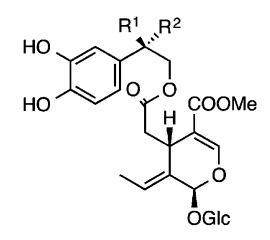

169: $R^{1}=O M e, R^{2}=H$ 170: $R^{1}=H, R^{2}=O M e$

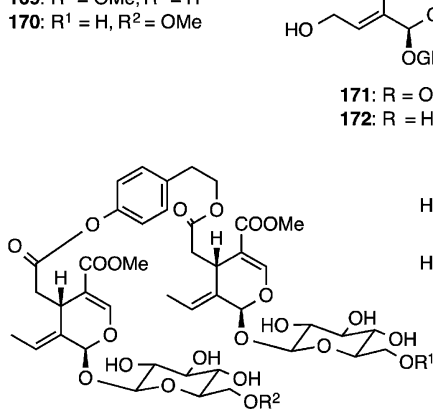

175: $R^{1}=$ ole, $R^{2}=H$
176: $R^{1}=H, R^{2}=$ ole
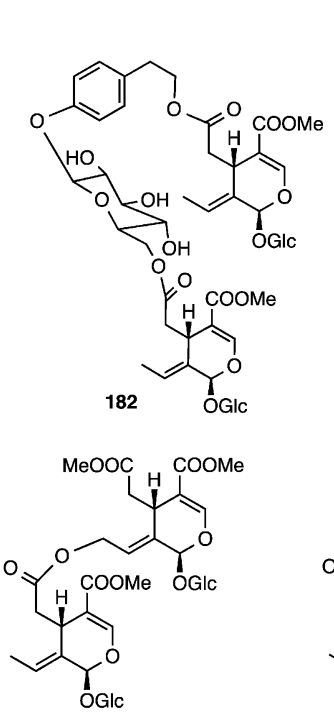

185
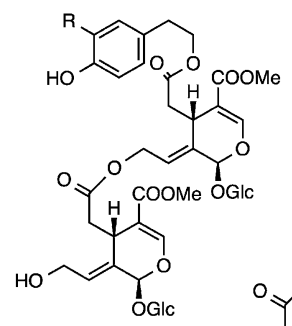

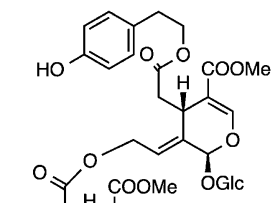<smiles>C=CC(C)C</smiles><smiles>CCCOCC=CC(O)C(=O)OC</smiles><smiles>C1CC2CCC(C1)CC2</smiles>
173 OGlc

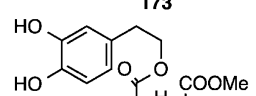

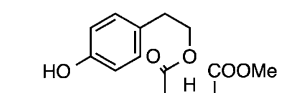

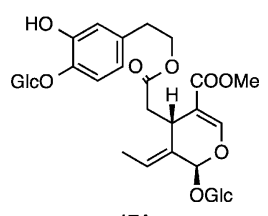

174

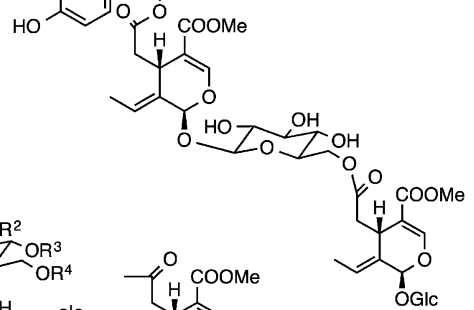

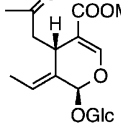

181 177: $R^{1}=$ ole, $R^{2}=R^{3}=R^{4}=H$ 179: $R^{1}=R^{2}=R^{4}=H, R^{3}=$ ole 180: $R^{1}=R^{2}=R^{3}=H, R^{4}=0$

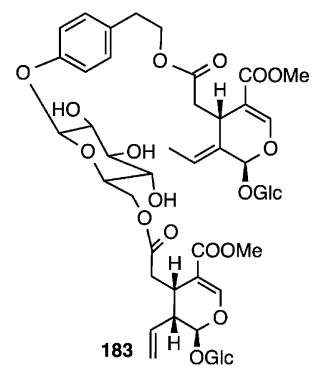

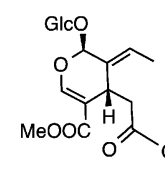

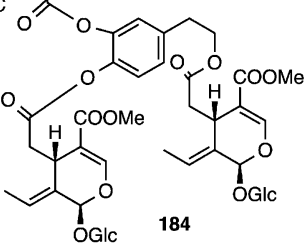
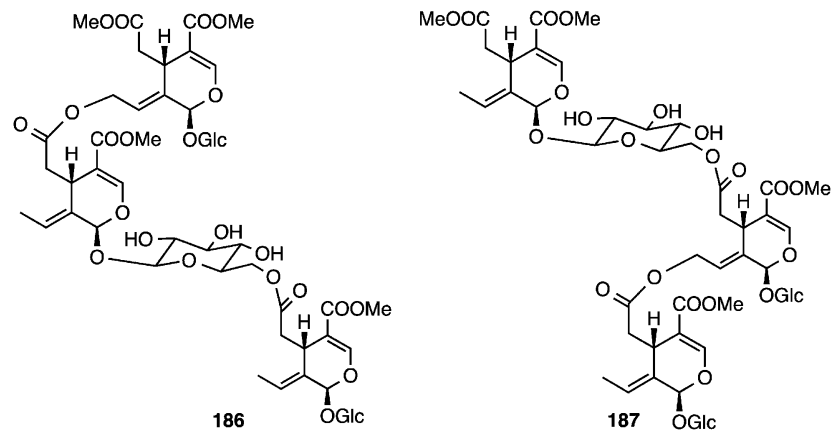

Fig. 22. New Secoiridoid Glucosides 169-187 from Jasminum spp.

methyl ester（125）がエステル結合した配糖体 175182, 184 や, 10-hydroxyoleoside 11-methyl ester (126) と oleoside 11-methyl ester（125）がエステル結合 を介して二量体や三量体となった 185-187 が得られ

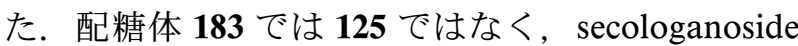
が結合していた（Fig. 22). ${ }^{55-57)}$

ソケイ属植物のイリドイド系配糖体で特徵的なこ とは，モノテルペン類とのエステル構造がみられる 点である.J. polyanthum では, oleoside 11-methyl ester（125） と直鎖状モノテルペンのエステル 188198 が得られた（Fig. 23）. ${ }^{58,59)}$ それに対してJ. hemsleyi では，イリドイド配糖体 loganin とモノテ ルペン menthiafolic acid のエステル 199-203 及び クマル酸のエステル 204, 205 が得られた（Fig. 24). ${ }^{60,61)}$

J. sambac, J. nudiflorum, J. mesnyi の配糖体で は，モノテルペン部は環化してシクロペンタン環を 形成している，J. mesnyi から単離された jasminin （123）がその代表的なもので, ${ }^{62)}$ 同植物より類似の

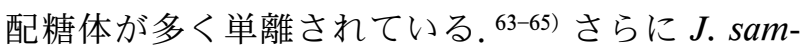
bac の葉部から配糖体 206-208, ${ }^{66)} J$. nudiflorum か ら，シクロペンタン環を持つモノテルペンと 1-3 個 


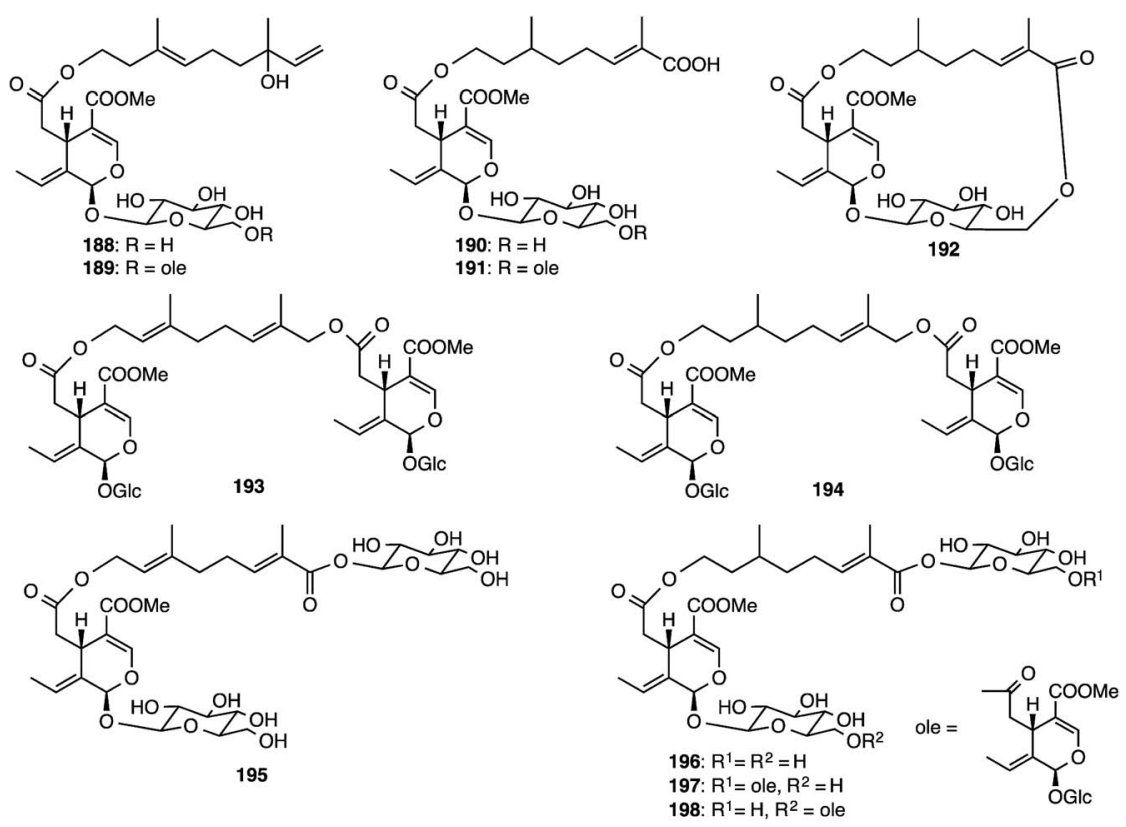

Fig. 23. New Secoiridoid Glucosides 188-198 from Jasminum polyanthum

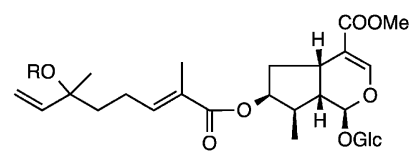

199: $\mathrm{R}=\mathrm{H}\left(6^{\prime \prime} S: 6^{\prime \prime} R=53: 47\right)$

200: $R=\beta$-Glc $\left(6^{\prime \prime} S\right)$

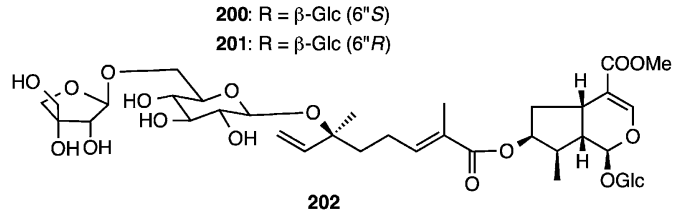

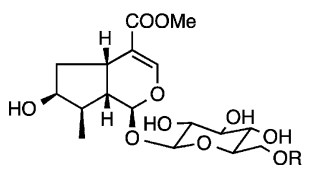

203: $R=\overbrace{O}^{R}=\overbrace{O}^{\mathrm{OH}}$

205: $\mathrm{R}=$ 七O $^{\mathrm{OH}}$

Fig. 24. New Iridoid Glucosides 199-205 from Jasminum hemsleyi

の oleoside（124）がエステル結合した配糖体 209224 を単離した. ${ }^{67-69)}$ また J. sambac からは, リグ ナンと 125 が結合した sambacolignoside (225), ${ }^{70)}$ J. nudiflorum からは, isooleoacteoside（226）を単 離した (Fig. 25).

J. sambac とJ. nudiflorum から単離した 206-224 及び J. mesnyi から単離した配糖体は環状テルペン 部を持つが，このシクロペンタン環の立体配置には 注目する必要がある。イリドイド炭素骨格の形成機 構は, geraniol(227)が 10-hydroxygeraniol を経て, 10-oxogeranial に変換され，このジアルデヒド体の iridodial (228) への還元的閉環によるものである. Iridodial（228）は，さらに酸化反応，配糖体化の 後, シクロペンタン環の開裂により oleoside が生 成すると考えられる。一方，配糖体 206-224 の環状 モノテルペン部も鎖状モノテルペンの環化により生
成し，仮想前駆体 229 のヒドロキシ化により多様な モノテルペン部が形成されると説明できる.しかし, iridodial のシクロペンタン環は 1,5-cis 配置で, 絶 対配置は $1 R, 2 S, 5 R$ であるのに対して, 環状モノ テルペン 229 のシクロペンタン環では 1,5-trans 配 置であり, 立体配置は iridodial と異なっている. このことから, ソケイ属の植物では, 閉環の立体化 学の異なる閉環酵素の存在が想定される。また,

149 と 167 においても, シクロペンタン環の絶対配 置はソケイ属の配糖体と異なっている。F. americana では 228 から酸化反応により生合成され ると考えられ，また S. afghanicaにおいても，228 に閉環後に立体配置の変換がおこる可能性も想定さ れるが，異なる閉環酵素の存在も否定できない (Fig. 26). 
<smiles>[R6]C[C@H](CO)[C@H]1C[C@H](O)[C@@H](C)[C@H]1CO</smiles>

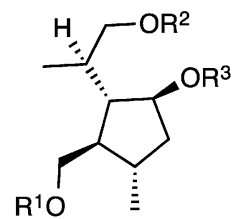

206: $R^{1}=R^{2}=R^{3}=$ ole, $R^{4}=H \quad$ 209: $R^{1}=$ ole $, R^{2}=H, R^{3}=$ ole 207: $R^{1}=R^{2}=R^{4}=$ ole, $R^{3}=H \quad$ 210: $R^{1}=$ ole,$R^{2}=R^{3}=H$ 208: $R^{1}=R^{3}=R^{4}=$ ole, $R^{2}=H$

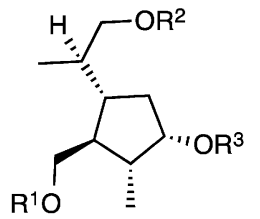

211: $R^{1}=R^{3}=$ ole, $R^{2}=H$

212: $R^{1}=R^{2}=R^{3}=$ ole

213: $R^{1}=H, R^{2}=R^{3}=$ ole

214: $R^{1}=R^{2}=$ ole, $R^{3}=H$

215: $R^{1}=$ ole, $R^{2}=R^{3}=H$

216: $R^{1}=R^{2}=H, R^{3}=$ ole

217: $R^{1}=R^{3}=$ ole, $R^{2}=\beta$-Glc

218: $R^{1}=$ ole, $R^{2}=\beta-G l c, R^{3}=H$

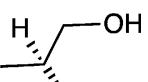

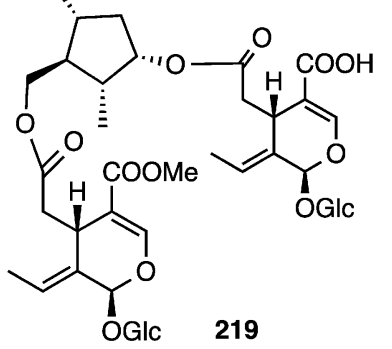

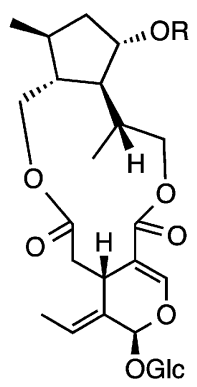

220: $\mathrm{R}=\mathrm{H}$ 221: $R=$ ole

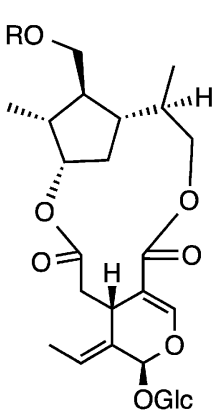

222: $\mathrm{R}=\mathrm{H}$

223: $R=$ ole

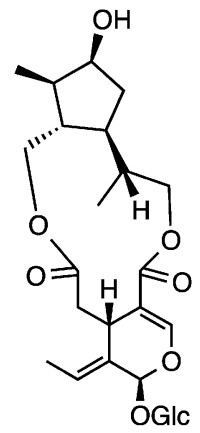

224

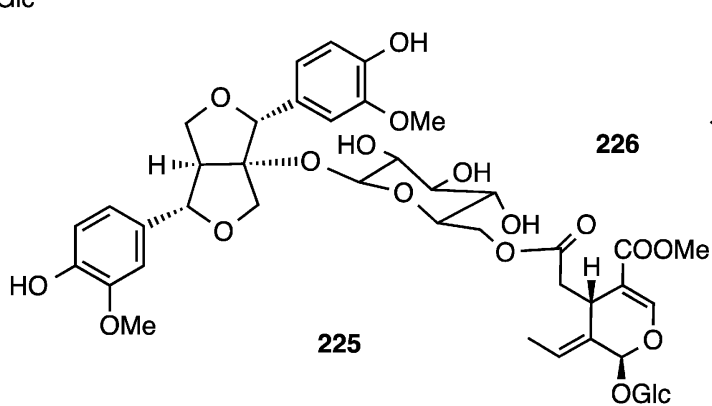

Fig. 25. New Secoiridoid Glucosides 206-226 from Jasminum sambac and Jasminum nudiflorum

2-2-4. イボタノキ属 Ligustrum vulgare のセコイ リドイドアグリコンＬigustrum vulgare L. から は 127, 128 などの既知配糖体のほか，新規配糖体 230, 231 を得た。さらにアグリコン ligustrohemiacetal A (232) と B (233) を単離し, 構造決定し た (Fig. 27). ${ }^{71)}$

化合物 232 は, スペクトルデータから，J. multiflorum から単離されている jasmolactone A と同

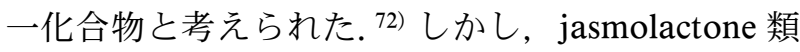
のスペクトルデータの解析, 及び加水分解後の生成 機構に疑問点があった。一方，オリーブの葉部か ら，アグリコン 234 が得られ，oleoside 型配糖体か ら酵素加水分解による生成機構が報告されてい

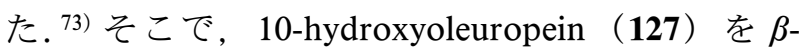
glucosidase により加水分解を行ったところ，232や 233 と同様のヘミアセタール構造を持つ化合物 235 が得られ，そのスペクトルデータは jasmolactone B と一致した. スペクトル解析と化学变換反応により,

235 の構造を決定し, jasmolactone 類の構造を訂正 した (Fig. 28).
2-2-5. Oleoside 型配糖体の生合成経路 モク セイ科に特徵的な oleoside 型配糖体は, 他のセコ イリドイド配糖体と同様，投与実験により secologanin（2）から生合成されると考えられてい た。また， 2 からの経路は不明であったが， ligustaloside 型化合物の存在と, エチリデン基の立 体化学的考察に基づき, 8S,10-epoxysecologanin （236）が生合成中間体として想定された。 ${ }^{74)}$ その 後, 投与実験において, ${ }^{75)} 236$ のトリチウム標識体 が oleoside 型, 10-hydroxyoleoside 型, ligustaloside 型配糖体に取り込まれたことから，8S,10-epoxysecologanin（236）が生合成経路の中間体である可 能性が示唆された（Fig. 29, Pathway A).

しかし，Jensen らのグループは， oleoside 型配糖 体が 2 から 236 を経て生合成されるとする説には取 り込み率の低さから否定的で，モクセイ科植物の配 糖体は deoxyloganic acid（237）を中間体とする種 々の経路を経て生合成されることを投与実験の結果 より示した (Fig. 29, Pathway B). またイリドイ ド配糖体の構造にはモクセイ科の属毎に特徵があ 

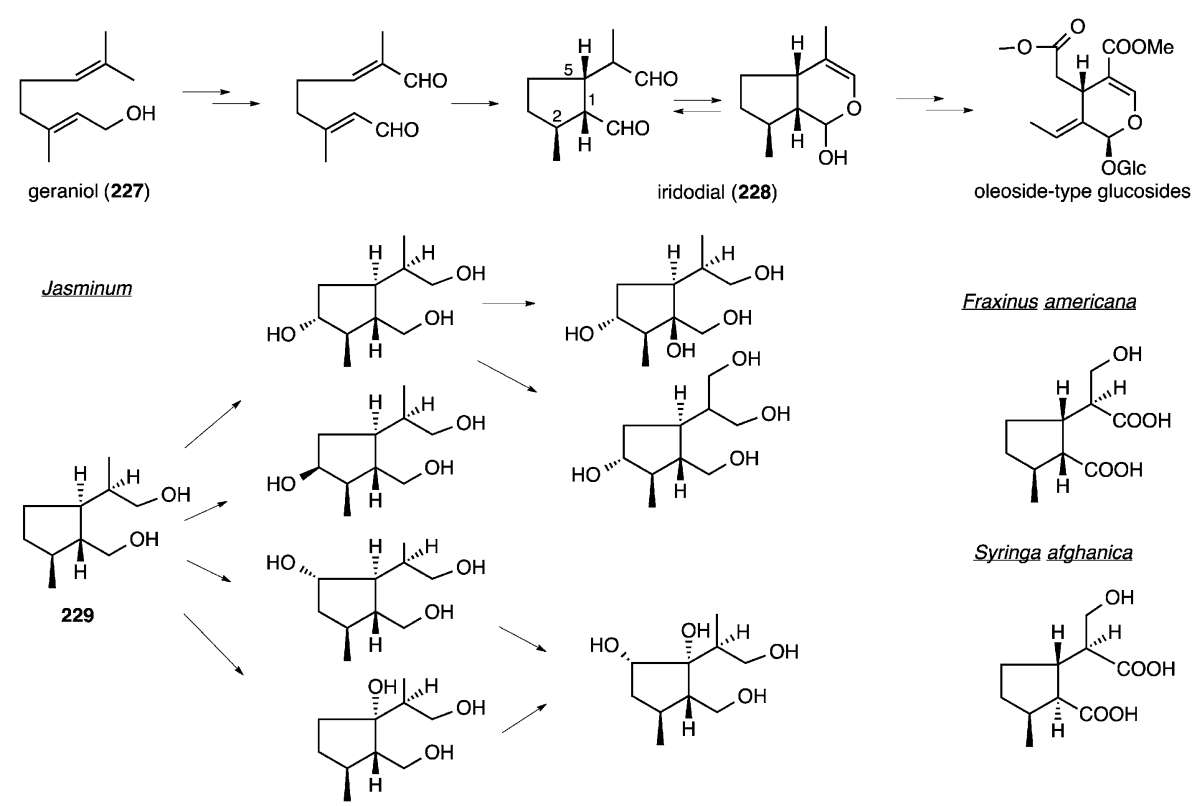

Syringa afghanica

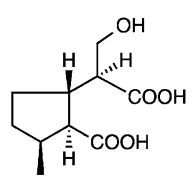

Fig. 26. Diversity of Iridane Skeletons of Oleoside-type Secoiridoid Glucosides in Oleaceous Plants

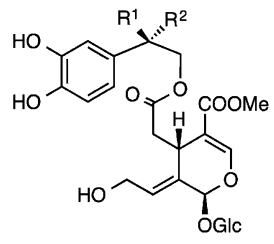

230: $\mathrm{R}^{1}=\mathrm{OMe}, \mathrm{R}^{2}=\mathrm{H}$ 231: $R^{1}=H, R^{2}=O M e$

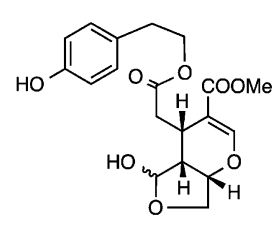

232

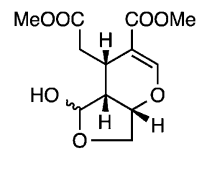

233

Fig. 27. New Secoiridoid Glucosides $\mathbf{2 3 0}$ and $\mathbf{2 3 1}$ and Unusual Recyclized Secoiridoid Aglycones 232 and 233 Isolated from Ligustrum vulgare

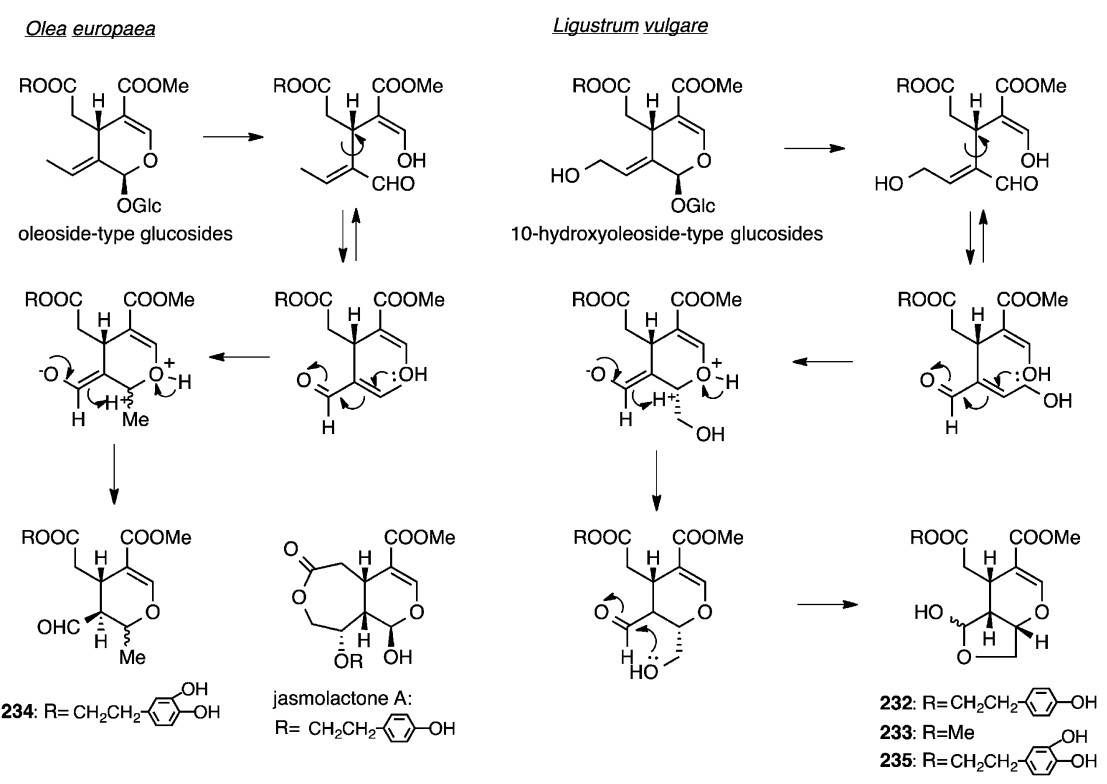

Fig. 28. Possible Reaction Scheme from Oleoside-type and 10-Hydroxyoleoside-type Secoiridoid Glucosides to Recyclized Aglycones 


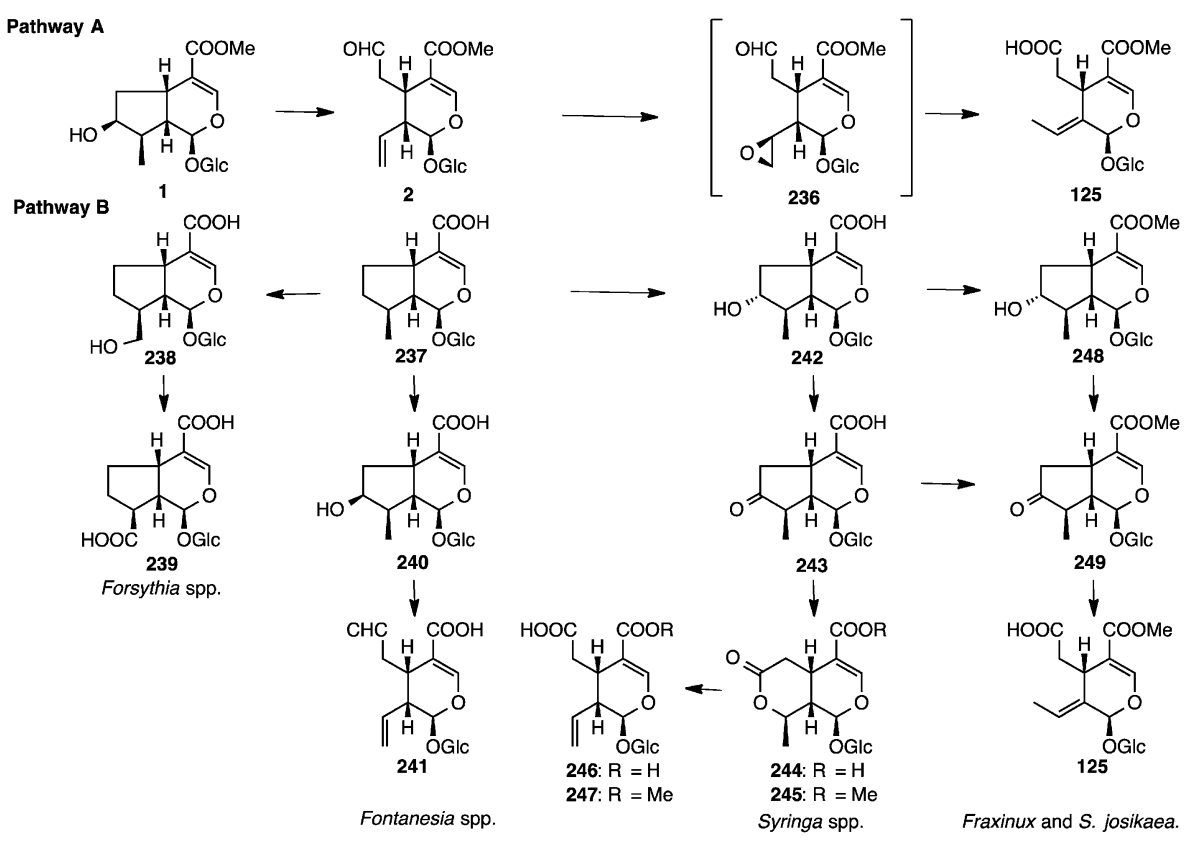

Fig. 29. Postulated Biosynthetic Pathways to Oleoside 11-Methyl Ester (125)

り，植物分類と生合成経路の関連について論じてい る. ${ }^{44)}$ Deoxyloganic acid（237）のC-10がヒドロキ シ化されると 238 になり，ついで forsythide（239） が生成する経路はレンギョウ属（Forsythia）にの み認められる。237 から loganic acid（240）を経て secologanic acid（241）に至る経路は，他科植物で は一般的なセコイリドイドの生合成経路であるが, モクセイ科では Fontanesia でのみ存在する。モク セイ科のセコイリドイド配糖体の多くは，240では なく7-epiloganic acid（242）を経て生合成される. ハシドイ属（Syringa）では，242 は ketologanic acid（243）に酸化され，epikingisidic acid（244） に至る。 244 又は epikingiside（245）からはラクト ン環の開環をともなつて, secologanoside（246）や secoxyloganin（247）が生成する可能性についても 言及している，これらの経路では，カルボン酸誘導 体として生合成されるが，トネリコ属 (Fraxinus) やハシドイ属の植物における oleoside 11-methyl ester（125）の生合成では，基質は 11-メチルエステ ルであり，7-epiloganin (248) が ketologanin (249) を経て oleoside 11-methyl ester（125）が生合成さ れると結論している.

筆者の研究室のモクセイ科植物の成分検索では, 単離した配糖体の多くは, oleoside 型若しくは 10hydroxyoleoside 型配糖体で，236 又は 8S,10-epoxy
環を持つ関連化合物は認められず， secologanin も モクセイ科植物に検出できなかった．それ以外の既 知物質として, F. formosana から 245, J. hemsleyi から 1 と 249, L. vulgare から 246 が単離された。 また J. hemsleyi には 1 と 249 が 10-hydroxyoleoside 型既知配糖体と共存しており，また，J.polyanthum から，分子中に oleoside と secologanoside 部分を持つ配糖体 183 が得られた. Oleoside 型セコ イリドイド配糖体は, secologanin 由来ではなく, 7-epiloganin (248), ketologanin（249）を経て生合 成されることが明らかにされたが，oleoside 型配糖 体と 1, 245, 246 が同一の植物に共存していること から, oleoside 型配糖体を含む植物内の生合成経路 は単一ではなく, 複数の経路が共存していると考え るのが妥当であろう.

Oleuropein の生合成経路において，ketologanin （249）から開環して oleoside 11-methyl ester（125） を生成する機構は，他科植物のセコイリドイド系化 合物でみられる loganin（1）から secologanin（2) の生成機構と大きく異なっており，興味は尽きな い. 最近，オリーブの網羅的な遺伝子発現解析が進 められ， olive iridoid synthase に関する報告がされ ている. ${ }^{76)}$ 更なる研究の進展による oleuropein 生合 成の全容解明に期待したい. 


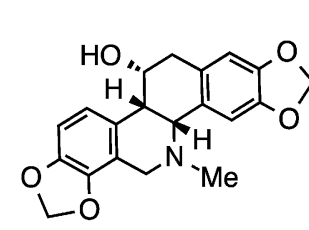

250

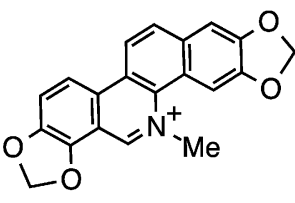

251

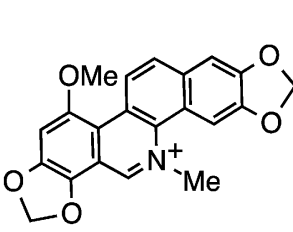

252

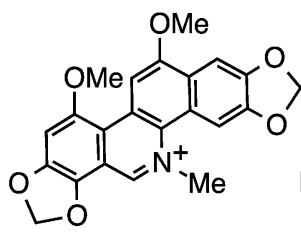

253<smiles>COC1=CC=C2C=C(c3c2ccc2cc4c(cc32)OCO4)[N+](C)=C1</smiles>

254

Fig. 30. Representative Benzophenanthridine Alkaloids<smiles>COc1ccc(C[C@H]2c3cc(O)c(O)cc3CCN2C)cc1O</smiles>

255<smiles>COc1cc2c(cc1O)[C@H]1Cc3ccc(OC)c(O)c3CN1CC2</smiles>

256<smiles>COc1cc2c(cc1O)[C@H]1Cc3ccc4c(c3CN1CC2)OCO4</smiles>

257

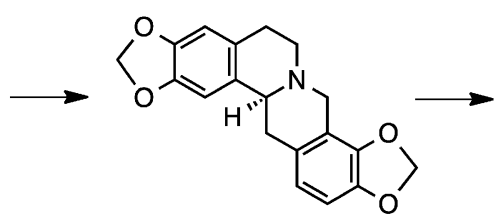

258

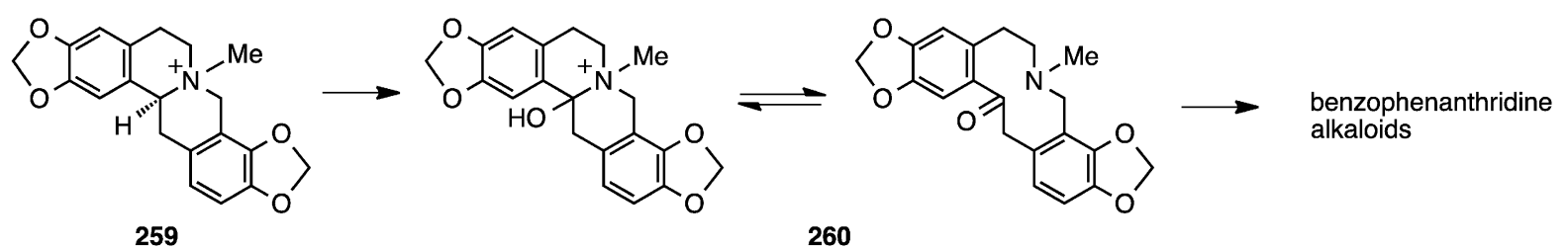

Fig. 31. Biosynthetic Sequence from Reticuline to Benzophenanthridine Alkaloids

3. イソキノリンアルカロイドの構造, 生合成, 生物活性

3-1. ベンゾフェナントリジンアルカロイドの生 合成 イソキノリンアルカロイドは薬用植物に含 まれる重要な生理活性物質で, 古くからその構造研 究，薬理活性の研究は活発に行われてきた．生合成 に関しても，当初は標識化合物の投与実験を中心 に，その経路の解明が行われてきた。1980 年代に なり, Zenk 教授らは植物の培養組織と酵素化学的 手法を駆使して, morphine, berberine の生合成過 程の全容を明らかにしていた，従来より，永倉教授 がこれらの研究に協力していたことから, Zenk 教 授の下で, ベンゾフェナントリジンアルカロイドの 生合成研究に取り組むことになった。

ベンゾフェナントリジンアルカロイドはミカン 科，ケシ科，ケマンソウ亜科に含まれ，代表的なも のとして chelidonine (250), sanguinarine (251), chelirubine (252), macarpine (253) や chelerythrine（254）が知られている（Fig. 30）。ベンゾ フェナントリジンアルカロイドの生合成について は，標識化合物の投与実験によって，（+）-reticuline $(\mathbf{2 5 5})$, scoulerine $(\mathbf{2 5 6})$, stylopine (258) が
250 の前駆物質であることが報告されていた。さら に Macleaya cordata の培養細胞を用いた投与実験 により 251, 252, 253 が stylopine (258), cis- $N$ methylstylopine (259), protopine（260）を経て生

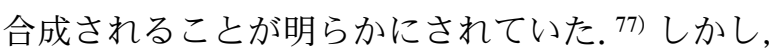
protopine (260) からベンゾフェナントリジンアル カロイドへの骨格変換の詳細な機構は不明であった (Fig. 31).

当時, Zenk 研究室では, (+)-reticuline (255) から scoulerine (256), cheilanthifoline (257), stylopine (258), cis- $N$-methylstylopine（259）を経 て protopine (260) へと至る生合成経路において, 二個のメチレンジオキシ基の形成と 259 のヒドロキ シ化の過程に, チトクローム P450 依存性のモノオ キシナーゼが関与していることが解明されつつあつ た. ${ }^{78)}$ そこで，チトクローム P450 酸化酵素による protopine（260）の6 位ヒドロキシ化の可能性を検 討した. ${ }^{79,80)}$ Protopine（260）の 6 位をヒドロキシ 化する酵素反応を検出するためには， 6 位が ${ }^{3} \mathrm{H}$ で 標識された protopine が必要であったので, 次に示 す方法で, $\left[6-{ }^{3} \mathrm{H}\right]-$ protopine $\left(\left[\mathbf{6 -}{ }^{3} \mathbf{H}\right]-260\right)$ を合成し た（Fig. 32).すなわち，260をオキシ塩化リンで 
<smiles>C=Cc1cc2c(cc1C(O)(CCc1ccc3c(c1CN(C)N)OCO3)Cc1ccccc1)OCO2</smiles>

(d)<smiles>COC(Cc1cc2c(cc1C(O)(CCc1ccc3c(c1N(C)N(C)C)OCO3)C(C)(C)C)OCO2)OC(C)(C)C</smiles>

(e)<smiles>CNCc1cc2c(cc1CC1O[C@@H](OC)Cc3cc4c(cc31)OCO4)[C@@H](Cc1ccc3c(c1)OCO3)O[C@H](OC)C2</smiles><smiles>CC#CCCOc1c(CC2O[C@H](O)Cc3cc4c(cc32)OCO4)ccc2c1OCO2</smiles><smiles>C[N+]1(Cc2ccc3c(c2C[C@H](O)[18OH])OCO3)CCCc2cc3c(cc21)OCO3</smiles>

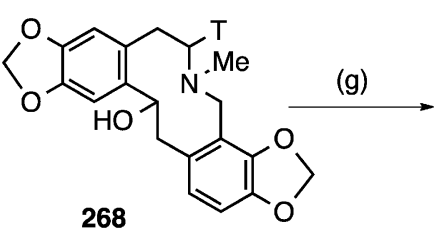

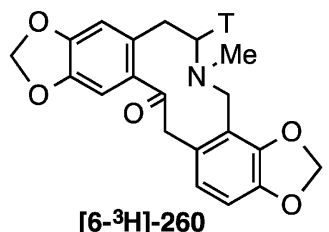

Fig. 32. Chemical Synthesis of $\left[6-{ }^{3} \mathrm{H}\right]$-Protopine $\left(\left[6-{ }^{3} \mathrm{H}\right]-\mathbf{2 6 0}\right)$

Reagents and conditions: (a) $\mathrm{POCl}_{3}, \mathrm{CH}_{3} \mathrm{CN}$, reflux, $1 \mathrm{~h}$; (b) $1.25 \% \mathrm{KOH}-\mathrm{MeOH}$, reflux, 10 min; 2 . $\mathrm{NaBH}_{3} \mathrm{CN}, \mathrm{MeOH}, \mathrm{pH} 5-6, \mathrm{rt}, 4$ h; (c) $\mathrm{BrCN}, \mathrm{MgO}$, THF- $\mathrm{H}_{2} \mathrm{O}$, rt, $24 \mathrm{~h}$; (d) TNN, $\mathrm{MeOH},-10^{\circ} \mathrm{C}$ to $0^{\circ} \mathrm{C}, 40 \mathrm{~min}$; (e) $\mathrm{LiAlH}_{4}, \mathrm{THF}, 0^{\circ} \mathrm{C}, 2 \mathrm{~h}$; (f) $1.10 \% \mathrm{HCl}, \mathrm{THF}, \mathrm{rt}, 48 \mathrm{~h}$; then $\mathrm{NaHCO}_{3}, \mathrm{pH}_{6.5-7.0 ; 2 .} \mathrm{NaB}^{3} \mathrm{H}_{3}$ $\mathrm{CN}, \mathrm{MeOH}-\mathrm{THF}-\mathrm{H}_{2} \mathrm{O}$, rt, 45 h; (g) PCC, NaOAc, $\mathrm{CH}_{2} \mathrm{Cl}_{2}$, rt, $2 \mathrm{~h}$.

処理し，得られた四級塩基 261 をホフマン分解に付 すことによりアルケン 262 を得た.これを $\mathrm{THF}-\mathrm{H}_{2} \mathrm{O}$ 中で $\mathrm{BrCN}-\mathrm{MgO}$ で処理することにより開環と同時 にヒドロキシ基を導入し，ついで 263 をメタノール 中, 硝酸タリウム（III）で酸化し， 264 と 265 の混 合物が得られた. ヘミアセタール体 264 を LAH に より還元的にシアノ基を除去した。 アミン 266 を $10 \% \mathrm{HCl}$ で加水分解後, $\mathrm{NaHCO}_{3}$ で $\mathrm{pH}$ を調整 し, この条件下で生成物はイミニウム塩 267 を形成 すると考えられるので, $\mathrm{NaB}^{3} \mathrm{H}_{3} \mathrm{CN}$ によって還元 的にトリチウムを導入した. 最終的に 268 のヒドロ キシ基を PCC 酸化すると, 目的とする $\left[6-{ }^{3} \mathrm{H}\right]-$ protopine（[6-3 $\left.{ }^{3}\right]$-260) が得られた。 $\mathrm{NaB}^{3} \mathrm{H}_{3} \mathrm{CN} の$ 還元反応では立体選択的に標識化されるが, 酸化し て得られる $\left[\mathbf{6}^{3} \mathbf{H}\right]-\mathbf{2 6 0}$ はキラル中心が消失するた め, 6 位のメチレンの水素は均等に標識されてお り，酵素反応の検出に好都合である．ヒドロキシ化 により標識されたトリチウムの半量は水として培地
中に放出され，酵素活性の測定が可能であり，トリ チウムの半量は生成物に保持され同定に役立つから である。

植物の材料としては Eschscholtzia californica の 培養細胞を用いた. この培養細胞は, ファイトアレ キシンの macarpine（253） を産生し, ${ }^{81)}$ エリシター として酵母の細胞壁の添加により macarpine 生合 成が誘導されるため, 生合成関連酵素の研究には最 適の材料であった。

E. californica の培養細胞に [6- $\left.{ }^{3} \mathrm{H}\right]$-protopine （[6-3 $\left.{ }^{3} \mathbf{H}\right]-260 ）$ を加えて培養すると, 期待通り強い 放射活性が培地中に検出されたことから，260の6 位がヒドロキシ化されていることが強く示唆され た. 求める酵素をミクロソーム結合性の P450 モノ オキシゲナーゼと予想し，E. californicaの培養細 胞のミクロソーム画分を調製し, この画分に $\left[6-{ }^{3} \mathbf{H}\right]-$ 260 を加えると酵素活性が認められた。エリシター で処理した培養細胞では未処理のものと比較して, 

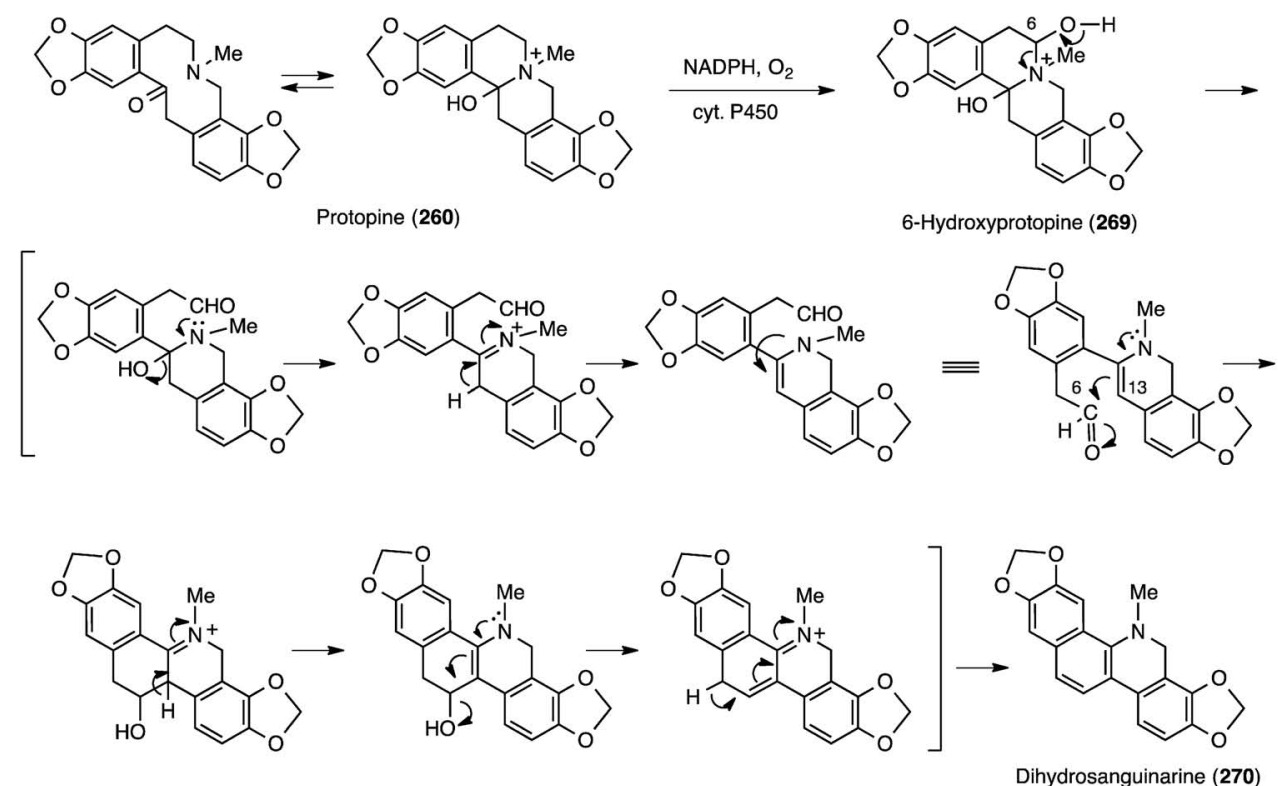

Fig. 33. Plausible Reaction Mechanism of Formation of Dihydrosanguinarine (270) from Protopine (260) Catalyzed by Protopine6-hydroxylase

その酵素活性は大きく増大した。一方，ベンゾフェ ナントリジンアルカロイドを生産しない Berberis stolonifera などの培養細胞のミクロソーム画分では 酵素活性が認められなかったことから，ベンゾフェ ナントリジンアルカロイド生合成に関与する酵素で あると言える。この酵素は，補酵素として $\mathrm{NADPH}$ ，また分子状酸素を要求し，この酵素反応 は，暗黒下で一酸化炭素により阻害されるが，光照 射で回復した。また，チトクローム P450 阻害剤に よって活性は阻害された事実から，本酵素はチトク ロームP450 酸化酵素であることを明らかにし, protopine-6-hydroxylase と命名した。しかし, 生成 物は 260 の 6 位ヒドロキシ化により生成した 6hydroxyprotopine（269）ではなく, dihydrosanguinarine（270）であった。 その生成は，260の 6 位ヒドロキシ化により生成した 6-hydroxyprotopine が非酵素的に enamine-aldehyde 中間体となり，C-6 と C-13 間で分子内縮合, 脱水反応が起こる機構で 説明できる (Fig. 33).

生成物の分析に際して，ラジオクロマトグラムで 270 に加えて，もう1 つの生成物のピークが認めら れた。この事実から，260から生成した $\mathbf{2 7 0}$ が，ミ クロソーム画分にある他のチトクローム P450 酸化 酵素によりさらに酸化を受けている可能性が考えら れ, macarpine (253) の生合成中間体の存在が推
定された。 そこで，エリシター処理により 253 の生 合成が強く誘導された E. californica 培養細胞の成 分検索を行った. ${ }^{82}$ 培養した液体培地より既知化合 物 251, 252, 253 とともに 3 種の新規アルカロイド, 10-hydroxysanguinarine (271), 12-hydroxychelirubine (272), 10-hydroxychelerythrine (273) が得ら れ，また培養細胞からは，培地から得られた化合物 に加えて 4 種のジヒドロベンゾフェナントリジンア ルカロイドを単離した。そのうち 10-hydroxydihydrosanguinarine（274） は新規化合物，他は既知 化合物 dihydrosanguinarine (270), dihydrochelirubine (275), dihydromacarpine (276) であった. さらに培養細胞のミクロソーム画分のアルカロイド を HPLC 分析すると 270，274，275，276 に加えて 12-hydroxydihydrochelirubine (277), 10-hydroxydihydrochelerythrine（278）のピークが検出され, また dihydrochelerythrine（279）と dihydrochelilutine（280）に相当するピークも認められた. 274 と 277 については単離同定した。しかし，それらが酸 化されたベンゾフェナントリジンアルカロイドはミ クロソーム画分に全く検出されなかった．以上の事 実から，260より生成した $\mathbf{2 7 0}$ が，ミクロソームの 膜結合性のチトクローム P450 酸化酵素により，10 位のヒドロキシ化を受けて 274 を生じ，その後メチ ル化を受けると 275 となり，さらに，12 位のヒド 


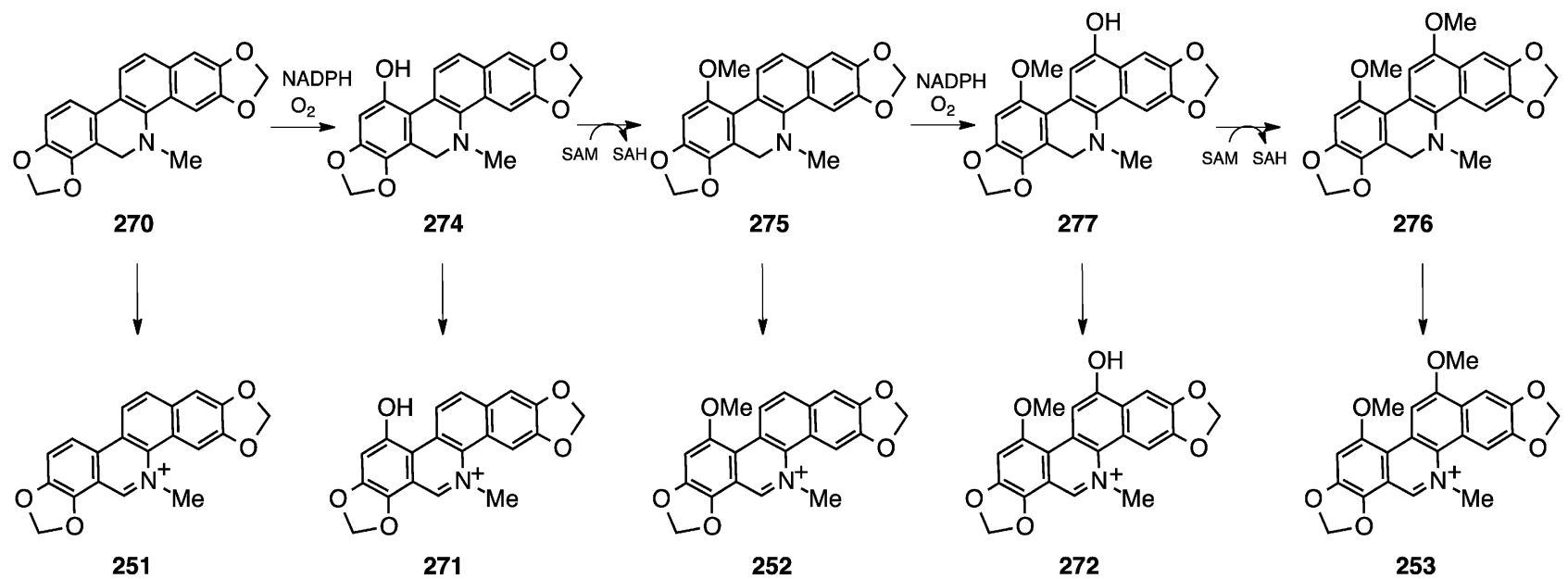

Fig. 34. Biosynthetic Pathway Leading from Dihydrosanguinarine (270) to Macarpine (253)

ロキシ化，メチル化により 276 が生成すると説明さ れる，その推定は，270をヒドロキシ化するチトク ローム P450酸化酵素 dihydrosanguinarine-10hydroxylase 及び 274 をメチル化する 10-hydroxydihydrosanguinarine-10- $O$-methyltransferase を $E$. californica の培養細胞に見い出すことによって証明 された。このメチル化酵素は基質特異性が高く,

274 のみをメチル化し，271，272，273，277 及び 278 をメチル化しなかった。. ${ }^{83)}$ その後, Zenk らによ り，エリシター処理をした Thalictrum bulgaricum 及び E. californica の培養細胞から 275 の 12 位をヒ ドロキシ化する dihydrochelirubine-12-hydroxylase 及び 277 のメチル化酵素が発見された. ${ }^{84)}$ メチル化 酵素の基質特異性から，メチル化はジヒドロ体で起 こり，271や 272 が直接メチル化を受けて 252 や 253 を生成する可能性は否定される。ジヒドロ体 270, 274-277 は基質特異性の低い細胞質の酵素 dihydrobenzophenanthridine oxidase $\left.{ }^{85}\right)$ によりベンゾ フェナントリジンアルカロイドへと酸化されると考 えられる。このように, macarpine (253) へ至る 生合成経路の全容が明らかとなった（Fig. 34）。こ の過程で，ミクロソームの膜結合性のチトクローム P450 酵素が重要な役割を果たしており，またこれ らの酵素はエリシター処理により強く誘導されるの に対して, 細胞質に存在するメチル化酵素は誘導を 受けないことも明らかとなった。

また, chelerythrine (254), chelilutine (281) の 生合成に関しては，E. californica の培養細胞から 273 を単離し，またミクロソーム画分に 278 を同定
したことから, marcarpine (253) の生合成の場合 と同様に，allocryptopine（282）から，チトクロー ム P450 酸化酵素，メチル化酵素，oxidaseによつ て生合成されると推定される (Fig. 35).

最近, Sato らはE. californica の培養細胞から protopine-6-hydroxylase $の$ cDNA を単離し，酵母 で発現させたリコンビナントタンパク質が, protopine（260）と allocryptopine（282）を，それぞれ dihydrosanguinarine (270) と dihydrochelerythrine （279）に変換することを示している。

3-2. ビスベンジルイソキノリンアルカロイドの 生物活性 ビスベンジルイソキノリンアルカロイ ドは，2 分子のベンジルイソキノリンアルカロイド が酸化的フェノールカップリングによって結合した 構造を持ち，ツヅラフジ科 (Menispermaceae)，キ ンポウゲ科などの植物から多数単離されている. ${ }^{87)}$ ビスベンジルイソキノリンアルカロイドには様々な 生物活性を持つものがあることから，生物活性に注 目しながら，ビスベンジルイソキノリンアルカロイ ド含有植物の成分検索を行つた.

3-2-1. 白薬子のセファランチンと関連化合物の 毛組織細胞増殖促進効果タマサキツヅラフジ Stephania cepharantha HAYATA は中国の四川，貴 州や台湾などに分布する多年生つる性の植物で，地 下部に塊根を有している。この塊根を乾燥した生薬 を白薬子と称する. 白薬子の成分研究の歴史は古 く，多数のビスベンジルイソキノリンアルカロイド が単離されている. 白薬子の生薬としての薬効は, ビスベンジルイソキノリンアルカロイドに起因して 
<smiles>COc1ccc(CC(=O)C2CCc3cc4c(cc3C2)OCO4)c(CN(C)C)c1OC</smiles>

282<smiles></smiles>

279<smiles>COc1cc(O)c2c(c1OC)CN(C)c1c-2ccc2cc3c(cc12)OCO3</smiles>

278<smiles>COc1cc(OC)c2c(c1OC)CN(C)c1c-2ccc2cc3c(cc12)OCO3</smiles>

280

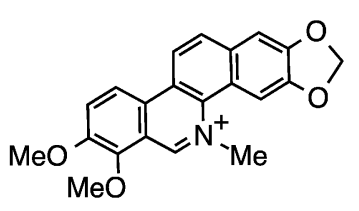

254

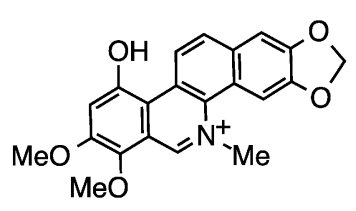

273

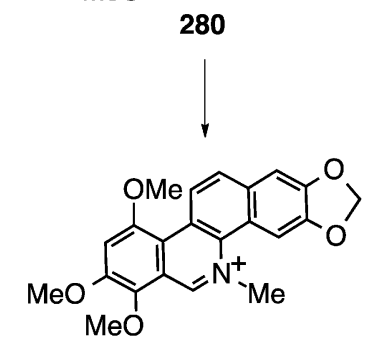

281

Fig. 35. Proposed Biosynthetic Sequence from Allocryptopine (282) to Chelerythrine (254) and Chelilutine (281)

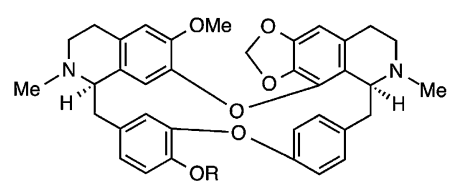

283: $R=M e$
284: $R=H$

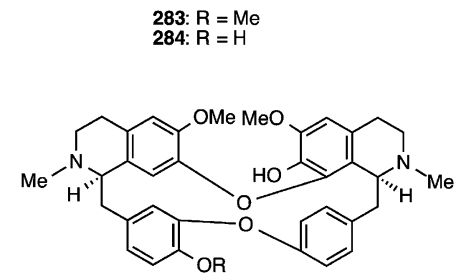

291: $R=\mathrm{Me}$
292: $R=H$

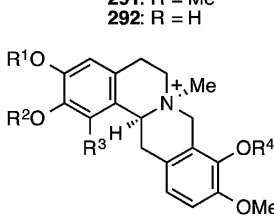

295: $R^{1}=R^{3}=R^{4}=H, R^{2}=M e$

296: $R^{1}=M e, R^{2}=R^{3}=R^{4}=H$

*297: $R^{1}=R^{2}=M e, R^{3}=O H, R^{4}=H$

298: $R^{1}=R^{2}=R^{4}=M e, R^{3}=O H$

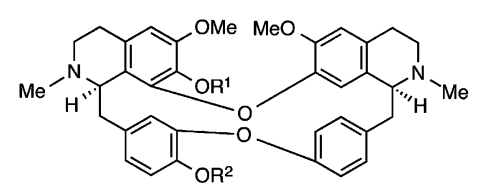

285: $R^{1}=R^{2}=M e$

286: $R^{1}=M e, R^{2}=H$

287: $R^{1}=H, R^{2}=M e$

288: $R^{1}=R^{2}=H$

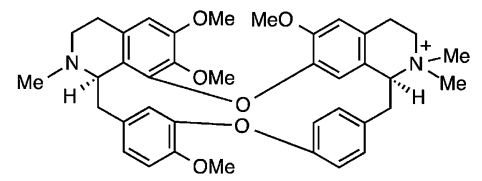

301

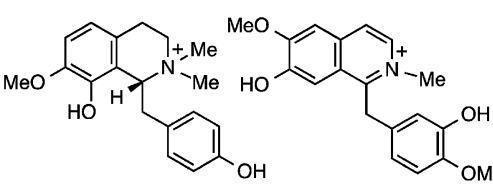

299

*300

255: $R=M e$
302: $R=H$

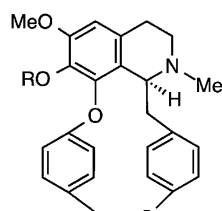

$\mathrm{Me}, \mathrm{H}$

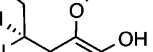

${ }_{\mathrm{OMe}}$

289: $\mathrm{R}=\mathrm{Me}$

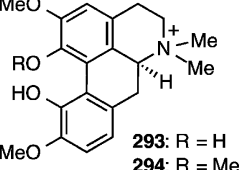

Fig. 36. Bisbenzylisoquinoline and Quarternary Alkaloids Isolated from Stephania cepharantha and Related Benzylisoquinoline Alkaloids

Asterisks indicate new compounds.

いると考えられる．主塩基の cepharanthine（283）

は，脱毛，白血球減少抑制剂として，また多剂耐性 克服剂として用いられている，いわゆる“セファラ ンチン”製剤は育毛効果が報告されており，283が 活性物質であると考えられるが, 他のビスベンジル イソキノリンアルカロイドの活性については未知で あった，そこで，白薬子のアルカロイド成分をさら に精査するとともに，その成分の育毛効果を評価し た.

白薬子の三級アルカロイド画分からはベンジルイ ソキノリンアルカロイド 283-292 を含む 14 種の既
知アルカロイドを単離した，四級アルカロイド画分 については，精製の困難さから精査されていなかつ たが，過塩素酸ナトリウムを用いたイオン対抽出と イオン対 HPLC 分取法により，新規アルカロイド stecepharine (297), tetradehydroreticuline (300) を含む，9種の四級アルカロイド 293-301 を単離し た (Fig. 36). ${ }^{88)}$

三級アルカロイド画分から得られた 9 種のビスべ ンジルイソキノリンアルカロイドと, 四級アルカロ イド画分から得られた $2^{\prime}-N$-methylisotetrandrine （301）の毛組織細胞増殖活性を評価した。 

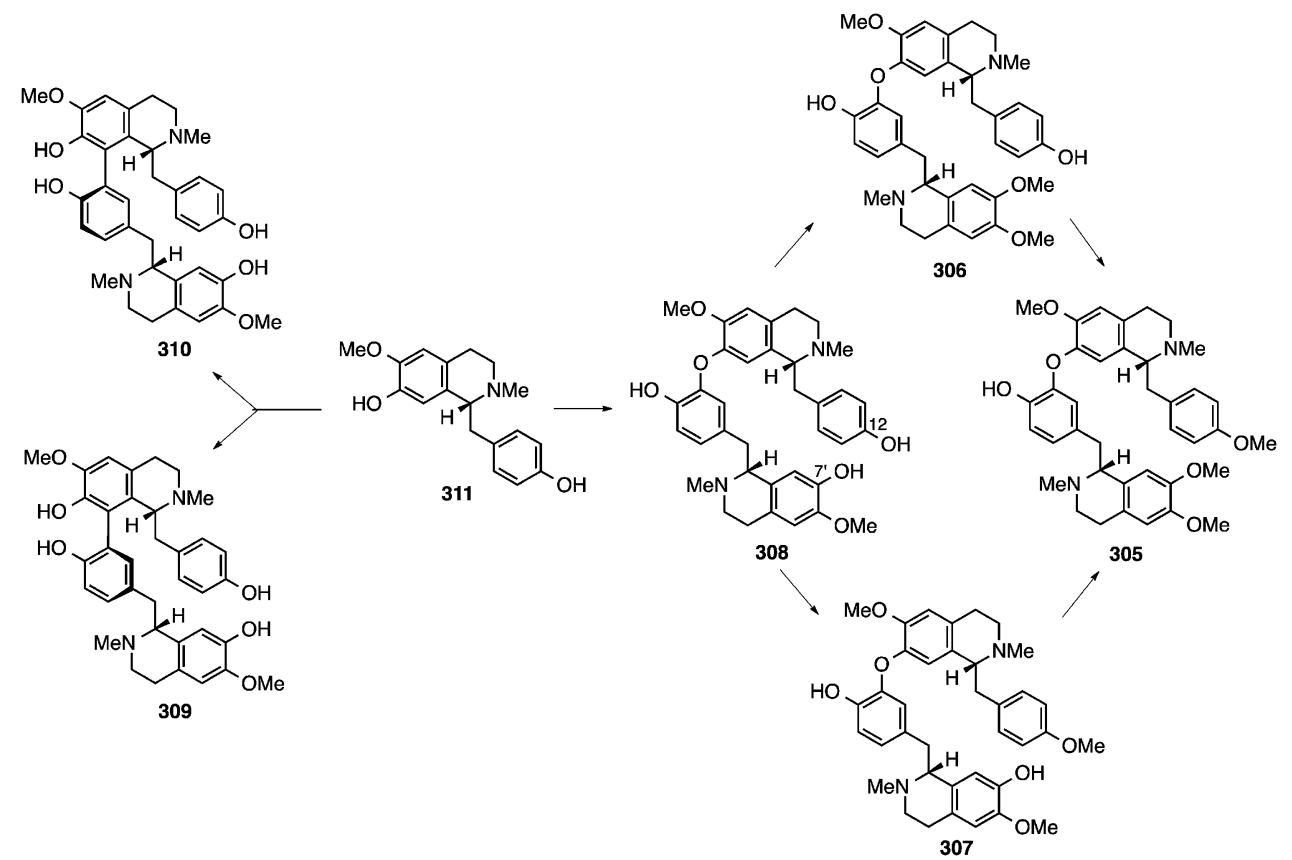

Fig. 37. Biogenetic Scheme from $(R)$-N-Methylcoclaurine (311) to Bisbenzylisoquinoline Alkaloids in Nelumbo nucifera

Cepharanthine（283）は $0.01 \mu \mathrm{g} / \mathrm{mL}$ でマウスの毛 組織から単離した培養細胞の増殖を促進し, cepharanoline (284), isotetrandrine (285), berbamine（286）も同様に，細胞増殖を六進させた。 そ の程度は，育毛剂として知られる $70 \mu \mathrm{g} / \mathrm{mL}$ minoxidilよりも，わずかに効果が大きかった。他の 6 種 のアルカロイドは効果を示さなかった。また， 283 と 284 は 0.01-0.1 $\mu \mathrm{g} / \mathrm{mL}$ で最大の効果を示した. 4 種のアルカロイドは，毛組織細胞に対して増殖を促 進するのに対して，マウスの皮膚から得たケラチノ サイトやフィブロブラストに対しては効果を示さ ず，毛包に特異的に作用することが明らかとなつ た. ${ }^{89)}$

Cepharanthine（283）などのビスベンジルイソキ ノリンアルカロイドが毛組織細胞に特異的に作用 し，毛成長を促進することが明らかとなった。これ らアルカロイドは $(S)$-及び $(R)$-ベンジルイソキ ノリンアルカロイドの二量体であることから，単量 体も同様に活性を示すのか，また立体化学の影響に ついて興味が持たれた。そこで， $(S)$-reticuline (255), $(S)$-norreticuline (302), $(R)$-reticuline (303)，（R）-norreticuline（304）を合成し，それぞ れの活性を評価した。その結果，255 と 302 は培養 毛組織細胞の増殖を促進し， $0.01 \mu \mathrm{g} / \mathrm{mL}$ において 最大の効果を示した。一方，303, 304 は顕著な効果
を示さず，明らかに立体特異性が認められた。 また， 255 と 302 は cepharanthine（283）と同様，ケラチ ノサイトやフィブロブラストに対しては効果を示さ なかった。さらに，in vivo での活性を見るため に，マウスに 1\%の $(S)$-norreticuline を塗布したと ころは $1 \%$ minoxidil とほぼ同程度の育毛効果を示 した. ${ }^{90)}$

3-2-2. 蓮子心の薬理作用とビスベンジルイソキ ノリンアルカロイド スイレン科植物ハス (Nelumbo nucifera GAERTNER) の成熟した種子の 胚芽を蓮子心と呼ぶ。蓮子心には，ビスベンジルイ ソキノリンアルカロイドが含まれていることが知ら れており，精神を安定させる目的で使用されてい る，東洋医学では心を清める，熱を去る，止血す る，精を鈍らせるなどの効能を持つ漢方薬として熱 病，労心吐血の治療に用いられている.したがって 蓮子心は中枢抑制作用を有することが予想される。 そこで，薬理活性を評価しながら，含有成分の検索 を行った.

まず蓮子心のメタノール抽出エキスを調べたとこ ろ，マウスに対して自発運動抑制作用を示した。つ いで，メタノールエキスを水と $n$-ヘキサン，クロ ロホルム, $n$-ブタノールで順次分配し, 各抽出物の 活性を評価した。 $n$-ヘキサン層， $n$-ブタノール層, 水層は活性を示さなかったが，クロロホルム抽出物 

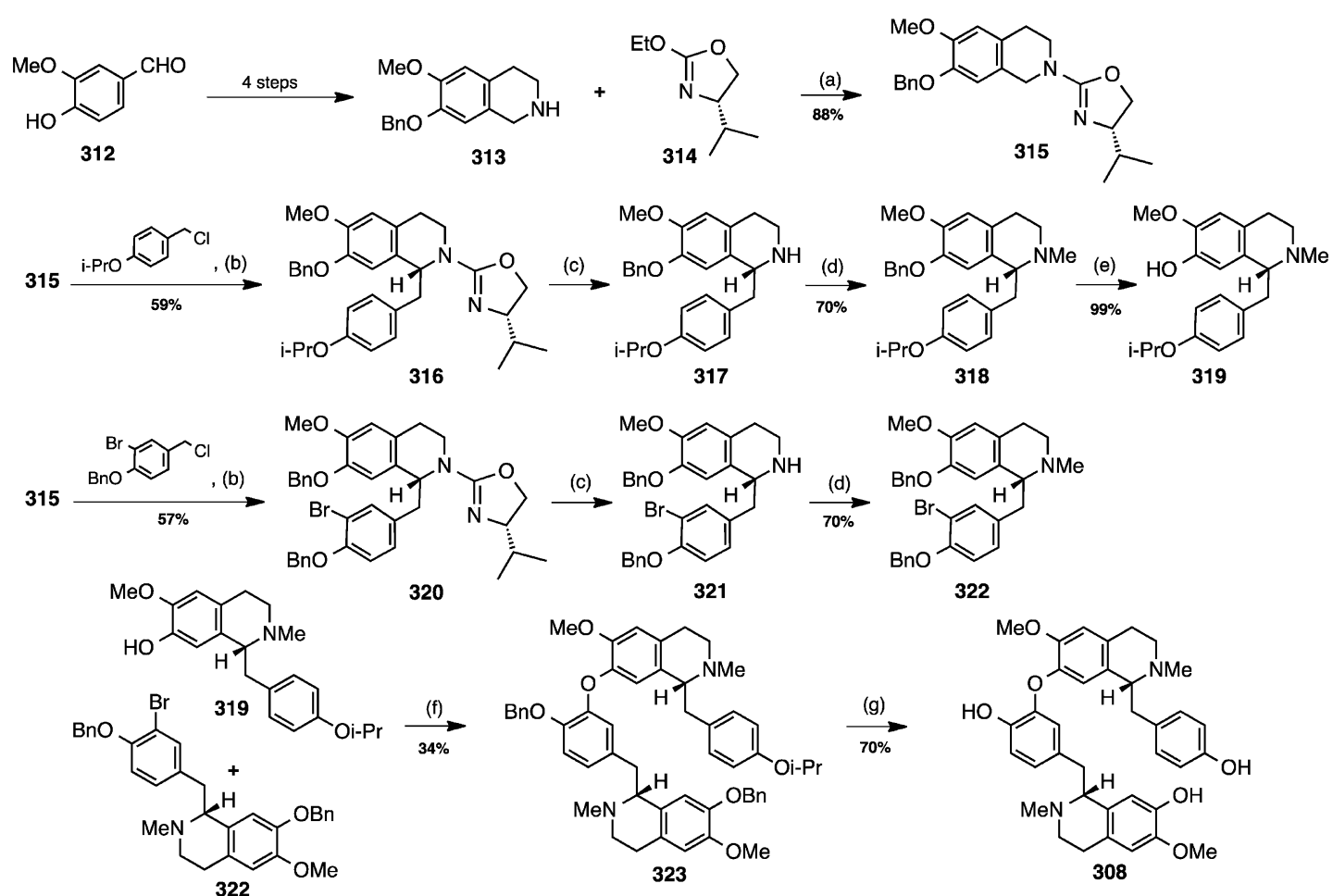

Fig. 38. Synthesis of Nelumboferine (308)

Reagents and conditions: (a) $p$-TsOH, $\mathrm{C}_{6} \mathrm{H}_{6}$, reflux, $2.5 \mathrm{~h}$; (b) $n$-BuLi, THF, -98 to $0^{\circ} \mathrm{C}, 2 \mathrm{~h}$; (c) hydrazine, $p$-TsOH, EtOH, reflux, $2 \mathrm{~h}$; (d) formalin, $\mathrm{NaBH}_{4}, \mathrm{MeOH}$, rt, $1 \mathrm{~h}$; (e) $\mathrm{H}_{2}, \mathrm{Pd} / \mathrm{C}, \mathrm{MeOH}, \mathrm{rt}, 7 \mathrm{~h}$; (f) $\mathrm{CuBr} \cdot \mathrm{SMe}_{2}, \mathrm{Cs}_{2} \mathrm{CO}_{3}$, pyridine, reflux, $20 \mathrm{~h}$; (g) $\mathrm{BCl}_{3}, \mathrm{CH}_{2} \mathrm{Cl}_{2},-15^{\circ} \mathrm{C}, 1 \mathrm{~h}$.

は明らかな自発運動抑制作用を示した。またクロロ ホルム抽出物にはビスベンジルイソキノリンアルカ ロイドが含まれていることから，主塩基の neferine （305）について精査すると，濃度依存的に自発運動 抑制を引き起こし，鎮静作用を示すことが明らかに なった。 また，体温降下作用，チオペンタールによ る睡眠持続時間の延長，抗不安作用を引き起こすこ とも明らかとなった. ${ }^{91}$

主塩基 neferine が中枢抑制作用を示したことか ら，クロロホルム抽出物に含まれる他のアルカロイ ド成分にも同様の活性を期待し，蓮子心のアルカロ イド成分の再検索を行つた．既知のビスベンジルイ ソキノリンアルカロイド neferine (305), liensinine (306), isoliensinine (307) とともに，新たに 3 種 のアルカロイド nelumboferine（308）と nelumborine A (309) , nelumborine B（310）を単離し，そ の構造を決定した。 ${ }^{92)}$ Nelumborine A (309) と nelumborine B（310）は回転異性体であり，ゆるや かに相互に変換する。 これらの新規アルカロイドの 生合成経路は，いずれも $(R)-N$-methylcoclaurine (311) を共通の前駆体とし，2 分子が C-O 酸化的 カップリングにより 308 を生じ，また一方， C-C
酸化的カップリングにより 309 と 310 が生成すると 考えられる，生合成中間体 nelumboferine（308） はさらにメチル化され, 蓮子心の主アルカロイド 305, 306, 307 が生合成されると考えられる（Fig. 37).

蓮子心からは，主塩基 neferine（305）とともに 306, 307, 308 が得られたので，これらビスベンジ ルイソキノリンアルカロイドの置換基の違いが薬理 活性に及ぼす影響を検討しようと考えた。 306, 307 は比較的多量に得られたが，新規アルカロイド nelumboferine（308） は微量しか含まれてないため 活性試験が困難であったので，全合成を行った。ま た，立体化学の薬理活性への影響を検討するために neferine（305）の立体異性体を全合成した.

新規化合物はベンジルイソキノリンの二量体であ るため，まずベンジルイソキノリンの単量体を合成 し，それらをUllmann 反応によりカップリングさ せて合成した，単量体の合成には，鍵反応として不 斉アルキル化を用いた。バニリン（312）より調製 したテトラヒドロイソキノリン 313 にキラル補助基 314 を縮合させ，アルキル化の基質 315 とした。 $\mathrm{THF}$ 中, $-98^{\circ} \mathrm{C}$ で 315 の不斉アルキル化を行った 


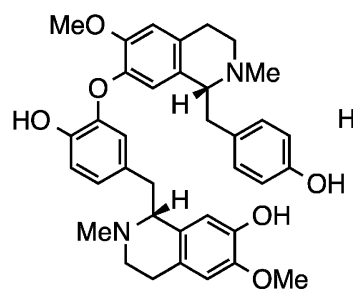

305

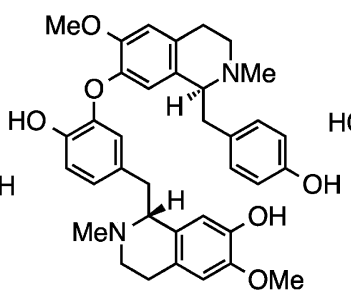

324

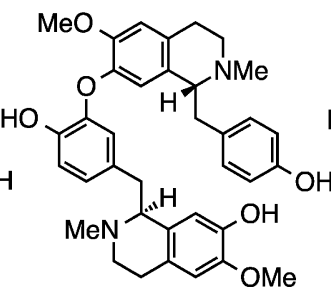

325

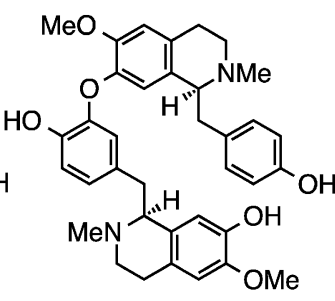

326

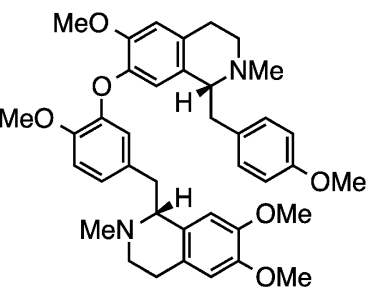

327

Fig. 39. Structures of Neferine (305), 1-epi-Neferine (324), $1^{\prime}$-epi-Neferine (325), ent-Neferine (326) and $O$-Methylneferine (327)

ところ，99\%以上の立体選択性で目的物 316 が得ら れた。 ヒドラジンによりキラル補助基を除去し,

317 の還元的 $N$-メチル化, 318 の接触水添によるべ ンジル基の脱保護を経て, 目的の上部単量体 319 へ と誘導した。同様にして, 315 から 320,321を経 て，もう一方の下部単量体 322 も合成した．臭化銅 ジメチルスルフィド錯体と炭酸セシウムを用いて,

319 と 322 の Ullmann カップリングを行い，得ら れた二量体 323 の脱保護によって目的のアルカロイ ド nelumboferine（308）が得られた（Fig. 38).

蓮子心のビスベンジルイソキノリンアルカロイド には 2 つのキル中心があるため, 4 つの立体異性 体が存在可能である，そこで, neferine（305）の立 体化学が薬理活性に及ぼす影響を調べるため, 前述 の新規アルカロイドと同じ合成法で，キラル補助基 として L-及び D-バリン由来のオキサゾリンを使い 分けることで, 305 の 3 種の非天然型立体異性体 1epi-neferine (324), 1'-epi-neferine (325), entneferine（326）を合成した。 また neferine（305） をメチル化することにより O-methylneferine（327） を得た（Fig. 39）.

化合物の置換基の相違が自発運動量に及ぼす影響 は neferine (305), liensinine (306), isoliensinine (307), nelumboferine (308) と $O$-methylneferine （327）を用いて検討した。いずれの化合物も自発運 動量を抑制し，その作用は 306, 307, 308 が 305, 327 よりも強力であった.この結果から, ビスベンジル イソキノリンアルカロイドの C-12 及び/又は C-7' の置換基がメトキシ基からヒドロキシ基に置き換わ ると鎮静作用が高まると考えられた。また，Omethylneferine (327) は作用発現が早く, その作用 は短時間で消失する傾向がみられた。

また, neferine (305), 1-epi-neferine (324), 1'epi-neferine (325), ent-neferine（326）の作用を比
較し, 立体化学の違いによる活性への影響を検討し た。その結果，いずれの化合物も自発運動量の抑制 を示した．その作用の強さは 325 >324 >326>305 の順に強いことが分かった.

以上，置換基の異なるビスベンジルイソキノリン 型アルカロイドの自発運動量の測定結果を比較した ところ，いずれの化合物も抑制作用を示し，またそ の強さには顕著な差がみられないことから自発運動 量抑制作用の発現には置換基よりもビスベンジルイ ソキノリン骨格が重要であると考えられる。また, 立体異性体の活性の比較検討の結果, 作用の強弱は 認められたが，明確な規則性はみられなかった. ${ }^{93)}$

Neferine（305） や liensinine（306）の他の中枢 作用についても検討し，抗うつ作用を示すこと，ま た抗うつ作用にセロトニン作動性神経が関連するこ とを明らかにしている. ${ }^{94,95)}$

\section{4. 単離培養地衣菌の代謝物}

地衣類は土袞，岩上，樹皮上などを覆うように生 育する共生生物で，共生関係を利用して地球上に広 く分布している。全世界で 400 属あまり，22000 種 以上が知られており, 外部形態から痂状地衣, 葉状 地衣, 樹状地衣の 3 種に大別される. 地衣体の大部 分は菌類の菌糸からつくられ，その中に微細な緑藻 や藍藻が共生しており, 分類学上は独立した生物群 とみなされる。構成菌類は藻菌類, 子囊菌類, 担子 菌類あるいは不完全菌類で, 大部分の地衣類は子囊 菌からなり, 現存する既知の菌類種の 5 分の 1 は地 衣化している。

地衣類は，食用地衣や色素，香料の原料として， また古来より世界各国で民間薬としても利用されて いる．地衣類は，化学的には地衣成分と呼ばれる地 衣類特有の化合物群を含有することで知られてい る. 地衣成分は既に 19 世紀には研究対象になり, 1831 年には vulpinic acid（328）が単離され，1883 


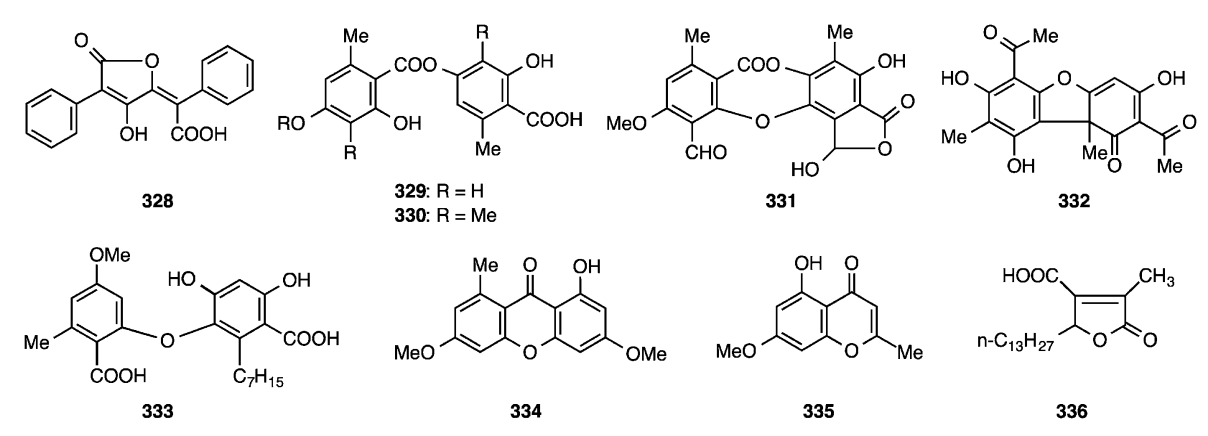

Fig. 40. Representative Lichen Substances

年に構造決定されたが，ほとんどの地衣成分の構造 は不明のままであった。 1920 年から 1945 年に, 朝 比奈らは多くの地衣成分の化学構造の解明に成功 し, これは日本における薬学, 天然物化学の歴史に 大きな位置を占めてきた. ${ }^{96)}$ 今日までにデプシド [lecanoric acid (329), barbatic acid（330）など], デプシドン [stictic acid（331）など], ジベンゾフ ラン [usnic acid（332）など], ジフェニルエーテ ル [ congrayanic acid (333) など], キサントン [lichexanthone（334）など], クロモン [eugentiol （335）など，，ラクトンカルボン酸［lichesterinic acid（336）など］などを基本骨格とする 800 種類 以上の地衣成分が構造決定されている (Fig. 40). ${ }^{97)}$ 芳香族化合物を中心とする地衣成分は, 植物や菌類 の代謝産物とは化学構造が異なり, 共生生物である 地衣類の特殊性を際立たせている。これら地衣成分 の地衣体における生理的な役割の詳細は明らかには されていないが, UV 照射に対する防御物質, 微生 物や植物の成長抑制物質, また昆虫の忌避物質とし ての役割を担っていると考えられている. ${ }^{98)}$ 地衣類 由来の成分には, 抗菌活性を始めとし, 抗ウイル ス, 抗腫瘍, 酵素阻害活性など幅広い生物活性が報 告され，その意義が再認識されている. ${ }^{99)}$

しかし, 天然の地衣体は成長が極めて遅いこと, また自然環境の変化に伴い生育分布が狭くなりつつ あることから，薬用資源としての活用には限りがあ ると考えられる。 その解決法の 1 つとして地衣類の 培養技術がある．地衣類の培養方法は種々検討され ており, 菌類と藻類が共存する状態で培養する方法 （組織培養）と，構成する菌類，藻類をそれぞれ分 離し個別に培養する方法（単離培養）が開発されて いる. 地衣菌の培養法としては, 生殖器官である子 器から胞子を放出させ, 無菌的に発芽させて純化培
養する方法が知られている.この方法は 1886 年以 来長らく続けられたが, 1960 年代になって Ahmadjian らによって集大成され，多くの地衣菌胞子 の放出発芽実験や地衣菌と地衣藻の再結合実験が種 々試みられている. 100)

一方, 地衣菌の培養による代謝物に関する研究は 多くなく, 1990 年代半ばまでで 20 数例あるだけ で, 地衣類の特徵的な成分であるデプシド類, デプ シドン類, クロモン類やアントラキノン類が培養地 衣菌で生産する例が報告されている。このように地 衣成分を単離地衣菌が生産している事実から，地衣 成分の生合成関連遺伝子は地衣菌がすべて備えてい ると考えられ，地衣藻は出発物質やエネルギーの供 給など間接的な関与に留まる可能性が指摘されるよ うになつた。現在までに, 地衣菌の培養条件につい て種々検討されているが, 大阪市立環境研究所の濱 田博士は, 胞子由来の地衣菌を, 寒天培地に高濃度 の糖を添加して高浸透圧条件下で培養を行うと, 地 衣本来の代謝産物やときには地衣成分とは異なる新 規化合物を大量に生産することを明らかにした. ${ }^{101)}$ そこで, 地衣菌の高浸透圧培養法に興味を持ち，共 同で日本国内及び海外で採集した痂状地衣類より胞 子由来の地衣菌を単離培養し, その代謝物の構造研 究を行った.

4-1. 地衣菌の単離培養による異常代謝物の生産

4-1-1. ダイダイゴケ科 Xanthoria 属地衣類の培 養地衣菌の代謝物 Xanthoria 属地衣類には emodin (337), parietin（338）などアントラキノ ン類が含まれていることは広く知られている.

Xanthoria polycarpa の地衣体の成分を分析すると 337-342 を，またX. elegans の地衣体からは337, 338, 341, 342 を検出した。 これら地衣より地衣菌を 単離培養したところ，X. polycarpa の培養地衣菌は 
<smiles>CCOc1cc(C)cc2c1C(=O)c1cc(O)cc(O)c1C2=O</smiles>

337: $R^{1}=R^{2}=R^{3}=H$ 338: $R^{1}=M e, R^{2}=R^{3}=H$ 339: $R^{1}=R^{2}=$ Me. $R^{3}=H$ 340: $R^{1}=R^{3}=M e, R^{2}=H$

Fig. 41. Anthraquinones from the Thalli and Cultured Mycobionts of Xanthoria polycarpa and Xanthoria elegans

338, 341, 342 を，また X. elegan の培養地衣菌は

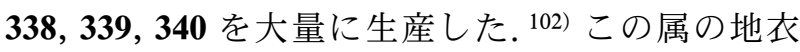
では，地衣菌が地衣成分の生合成に関与する遺伝子 をすべて備えており，地衣成分の生合成の主体は地 衣菌で，共生藻は特別な役割を果たしていないと考 えるのが妥当である（Fig. 41）.

4-1-2. モジゴケ科 Graphis 属地衣類の培養地衣 菌の代謝物モジゴケ科 Graphis 属地衣は世界で 約 340 種が知られ，熱帯地域に多く，日本には 30 種以上が分布している。哭が鉛筆で文字を走り書 きしたような模様からモジゴケと称されている．天 然の地衣体からは，デプシド類，デプシドン類など の地衣成分が知られているが，Graphis 属地衣の地 衣菌の単離培養についての報告はごくわずかであつ た.

Graphis scripta var. pulverulenta より地衣菌を単 離培養したところ，新規代謝物 graphislactone A-D (343-346）が得られた. ${ }^{103)}$ 343-345 は不完全糸状菌 類 Alternaria tenuis のマイコトキシン arternariol (347) と同じ $6 H$-dibenzo $[b, d]$ pyran-6-one 骨格を 持ち，また 343 は Botrytis allii の代謝物 botrallin （348）の還元体に相当するものである. Graphislactone A-D は，通常の地衣成分とは異なり，菌代 謝物と類似した骨格を持つ異常代謝産物であった. また G. prunicola（アメリカ産）の地衣菌からは 343-346 と graphislactone E (349), graphislactone F（350）が，G. cognata（愛媛産）の地衣菌からは 343, 345 と 347 が，G. scripta（スロベニア産）の

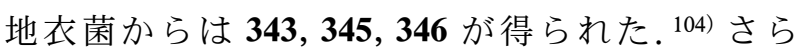
に, 和歌山, 長野, カナダで採取した G. scripta や，長野，岩手，高知，長崎など各地で採取した G. cognata の地衣菌培養でも同様に graphislactone 類の生産が認められた. ${ }^{105)}$ このように Graphis 属地
衣の地衣菌培養では，地理的に離れた採集地域の地 衣でも，また異なる種のものでも graphislactone 類 を共通に生産しているという結果が得られた。その 後, 海綿の内生菌 Ulocladium botrytis から 346 の 8-デメチル体 ulocladol（351）が単離され, ${ }^{106)}$ また 植物の内生菌 Cephalosporium acremonium IFBE007 の培養物から, graphislactone A (343) の類 似化合物 graphislactone G（352）と H (353) が単

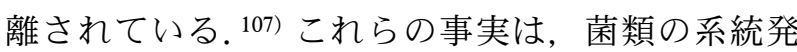
生学的な考察をする上で興味深い結果と考えている (Fig. 42).

一方，同種の Graphis scripta であっても，採集 地の異なる株によって，全く異なる代謝経路が発現 する場合もあった。栃木県・日光で採取した $G$. scripta の培養地衣菌からは 3 種のクロモン類 354356 が得られた。 ${ }^{108)}$ また同じく日光で採取した $G$. scripta の別株からは $357(4 R: 4 S=3: 7), 358(2 S$, $3 S, 4 R: 2 R, 3 R, 4 S=10: 9), 359 \quad$ (enantiomeric mixture $73: 27 ）$ が, いずれもエナンチオマーの混

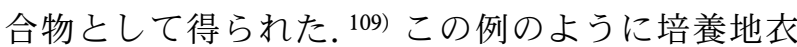
菌の代謝物は光学異性体の混合物であることが多 い.またアメリカ・アラバマで採集した G. scripta の培養地衣菌からは360が得られた（Fig. 42）。110)

さらに 9 種の Graphis 属地衣から地衣菌を単離培 養し，代謝物の検索を行った（Fig. 43）。フィリピ ン産の未同定の Graphis sp. からはイソクマリン $361(10 R: 10 S=19: 1)$ と $362(10 R: 10 S=18: 7)$ がエナンチオマーの混合物として得られた. ${ }^{111)}$ ま た G. scripta var. serpentina からは 3,3'-dihydroxy5,5'-dimethyldiphenyl ether (363), G. rikuzensis か らは violaceol-I（364）, violaceol-II（365） と新規 三量体 rikuzenol (366) が得られた。 ジフェニルエー テル類 363, 364, 365 はこれまで真菌類より単離さ れた例はあるが，これらを地衣類や地衣菌から単離 したのは初めてである. ${ }^{112)}$ G. apriens からは新規化 合物 $367(3 R: 3 S=3: 2), 368(3 R, 4 R: 3 S, 4 S=$ $49: 1)$ が，既知クロモン 354-356, 6-methoxymellein (369), graphisquinone（370）及び ergosterol（371）とともに得られた。 G. handelii から は, チオフェン環を持つ thiographisquinone（372） を 354, 369, 370 とともに得た。また G. awaensis からも 372 とともに 354，369，370，371 を単離し た. ${ }^{113)}$ G. proserpens の培養地衣菌からは 6 種の新 
<smiles>COc1cc(O)c2c(=O)oc3c(O)c(OC)cc(C)c3c2c1</smiles>

*343: $R^{1}=R^{2}=H$

*344: $R^{1}=\mathrm{Me}, \mathrm{R}^{2}=\mathrm{H}$ *345: $\mathrm{R}^{1}=\mathrm{H}, \mathrm{R}^{2}=\mathrm{OH}$<smiles>COc1cc(O)c2c(oc(=O)c3c(O)cc(O)cc32)c1O</smiles>

*349: $\mathrm{R}=\mathrm{Me}$ *350: $\mathrm{R}=\mathrm{H}$<smiles>CC1=C(C(=O)O)C(=O)OC1=O</smiles><smiles>COc1cc(O)c2c(=O)oc3cc(OC)c(O)c(O)c3c2c1</smiles>

*346: $\mathrm{R}=\mathrm{Me}$ 351: $\mathrm{R}=\mathrm{H}$<smiles>COc1cc(O)c2c(=O)oc3cc(OC)c(Cl)c([N+](=O)[O-])c3c2c1</smiles>

352<smiles>C[C@H]1OC(=O)[C@H](C)[C@@H]1C(=O)O</smiles><smiles>O=c1oc2cc(O)cc([N+](=O)[O-])c2c2c(O)cc(O)cc12</smiles>

$347: R=H$<smiles>COc1cc(O)c2c(=O)oc3c(OC)c(OC)cc([N+](=O)[O-])c3c2c1</smiles>

353<smiles>C=C(C(=O)O)C(CC)C(=O)O</smiles>

*359<smiles>COC1=CC2(C)OC(=O)c3c(O)cc(OC)cc3C2=C(O)C1=O</smiles>

348<smiles>CCCc1oc2cc(OC)cc(O)c2c(=O)c1CCC</smiles>

354: $\mathrm{R}^{1}=\mathrm{R}^{2}=\mathrm{H}$ *355: $\mathrm{R}^{1}=\mathrm{OH}, \mathrm{R}^{2}=\mathrm{H}$ *356: $\mathrm{R}^{1}=\mathrm{H}, \mathrm{R}^{2}=\mathrm{OH}$<smiles>O=c1ccc2cccc(O)c2o1</smiles>

360

Fig. 42. Metabolites 343-360 Isolated from Cultured Mycobionts of Graphis spp. and Related Fungal Metabolites Asterisks indicate new compounds.

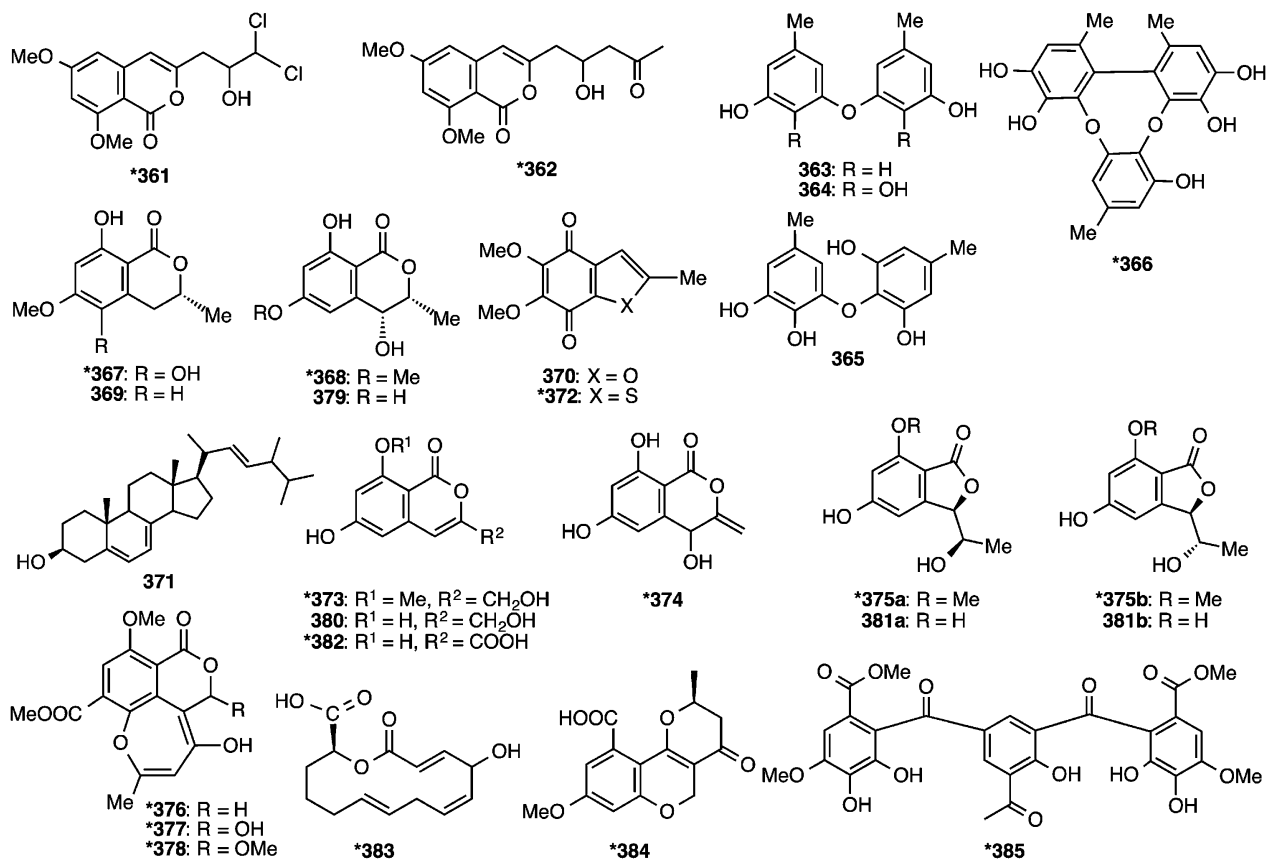

Fig. 43. Metabolites 361-385 of Cultured Mycobionts of Graphis spp. Asterisks indicate new compounds.

規化合物 373-378 を既知化合物 379-381 とともに得 た. Proserin A-C (376-378) は天然物として初め て単離された 7-oxo-5,7-dihydrooxepino [4,3,2-de] isochromene 誘導体である. ${ }^{114)}$

さらに，ベトナム産の G. vestitoides から，374, 379, 380, 381 とともに新規化合物 382 と 14 員環マ クロライド graphilide (383) を単離した。 14 員環 マクロライドは，海洋天然物や菌代謝物としての報
告はあるが，培養地衣菌から単離したのは初めての 例である.115) また未同定の Graphis sp. からは 376 と 2 種の新規化合物 384 と graphisidin（385）を単 離, 構造決定した。両化合物と関連のある 3,4-dihydro- $2 H, 5 H$-pyrano $[3,2-c]$ chromene 誘導体や benzophenone 誘導体は菌代謝物として報告はある が，地衣菌代謝物には例はない. ${ }^{116)}$ 
<smiles>[2H]c1c(O)cc(C)c2c1oc1c(Cl)c(O)cc(C)c12</smiles>

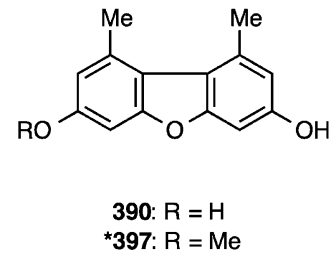<smiles></smiles><smiles>[R]c1c(O)c([R])c2oc3cc(O)cc(C)c3c(=O)c2c1O</smiles>

391: $\mathrm{R}^{1}=\mathrm{R}^{2}=\mathrm{H}$ 392: $\mathrm{R}^{1}=\mathrm{Cl}, \mathrm{R}^{2}=\mathrm{H}$ 393: $R^{1}=R^{2}=\mathrm{Cl}$<smiles>COc1cc2c3c(c(O)cc4c3c1COC4=O)CO2</smiles><smiles>[R]c1c(O)c(Cl)c2oc3c(Cl)c(O)c([R])c(O)c3c(=O)c2c1[R]</smiles>

$$
\text { 394: } R^{1}=R^{2}=H
$$
395: $\mathrm{R}^{1}=\mathrm{Cl}, \mathrm{R}^{2}=\mathrm{H}$ 396: $R^{1}=R^{2}=\mathrm{Cl}$<smiles>Cc1cc(O)cc2oc3cc(O)c(Cl)c([N+](=O)[O-])c3c12</smiles>

*398: $\mathrm{R}=\mathrm{H}$ *399: $\mathrm{R}=\mathrm{Me}$<smiles></smiles>

*389

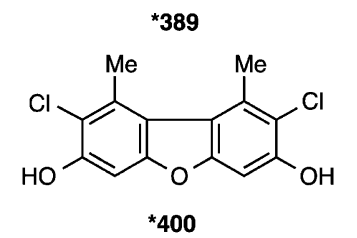<smiles>CCCCC=CC(C(=O)OC)=C(C)C(OC)OC(C)(C)C</smiles>

Fig. 44. Metabolites 386-403 of Cultured Mycobionts of Lecanora spp. Asterisks indicate new compounds.

\section{4-1-3. チャシブゴケ科 Lecanora 属地衣類の培} 養地衣菌の代謝物Ｌecanora iseana の培養地衣 菌からは新規化合物 386-389 とともに既知化合物 390-396 が得られた. ${ }^{117)}$ L. leprosa（=L. cinereocarenea）の培養地衣菌からは 390 と新規ジベンゾ フラン 397-400,118) 及び naphtho $[1,8-c d]$ pyran-3one 骨格を持つ lecanopyrone (401) ${ }^{119)}$ が得られた.

L. nipponica の培養地衣菌からは 2 種の新規カルボ ン酸誘導体 402 と 403 を単離した (Fig. 44). ${ }^{120}$

4-1-4. サネゴケ科 Pyrenula 属地衣類の培養地衣 菌の代謝物＼cjkstart奈良で採取した Pyrenula japonica と北アメリカ産のP. pseudobufonia の培養地衣菌 からは，既知キサントン $\mathbf{4 0 4}$ 及び新規化合物 $\mathbf{4 0 5}$ と 406 を得た。 ${ }^{121)}$ また滋賀で採取した $P$. japonicaの 別株の培養地衣菌からは 404-406 とともに新規キサ ントン 407 及び 408 と既知化合物 emodin (337) と sclerotiorin（409）を得た. ${ }^{122)}$ 宮崎で採取した未同 定の Pyrenula sp. の地衣菌培養からは toralactone (410) と naphtho [1,8-cd] pyran-3-one 骨格を有す る新規化合物 pyrenulin（411）を得た. ${ }^{123)}$ 徳島で採 取した未同定の Pyrenula sp.の培養地衣菌から は，新規化合物 412, 413, 414 (enantiomeric mix-

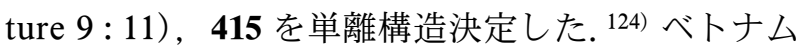
で採取した未同定の Pyrenula sp.の培養地衣菌か らは, 既知化合物 337, 405, 416 とともに新規化合
物 pyrenulic acid $\mathrm{A}-\mathrm{H}$ （417-424）を得た（Fig. 45). ${ }^{125)}$

キサントン 404-406 は, 地衣体から得られる norlichexanthone（391）と異なり，3 位にメチル基 あるいはヒドロキシメチル基を持つことから，生合 成におけるポリケチド鎖の閉環様式は, Pyrenula 属の培養地衣菌では地衣体と異なっていると考えら れる。また，409（アザフィロン骨格），411 (naphthalene 骨格 )，412-414（5,8-dihydroxyisocoumarin 誘導体)， 417-424（アルキル化デカリ ン型ポリケチド)，415 (ベンゾフラン）のような骨 格を持つ化合物をこれまで培養地衣菌から単離した 例はない.

また pyrenulic acid 類の生物活性を評価したとこ ろ, pyrenulic acid A (416) と pyrenulic acid G (423) の DNA polymerase $\alpha$ と $\beta$ の阻害活性は $\mathrm{IC}_{50}$ は 8.1-19.5 $\mu \mathrm{M}$ ，また， pyrenulic acid A の HCT116 ヒトがん細胞の増殖阻害活性は $\mathrm{IC}_{50} 6.4 \pm 0.7 \mu \mathrm{M}$ で あった。

4-1-5. その他の地衣類の培養地衣菌の代謝物 Haematomma sp.の培養地衣菌より, (一)-usnic acid (332)，425 と新規化合物 8-methylascomycone

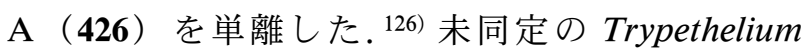
sp. の培養地衣菌からは新規化合物 $\mathbf{4 2 7}$ と 428 を既 知化合物 $(+)$-trypethelone methyl ether (429) と 


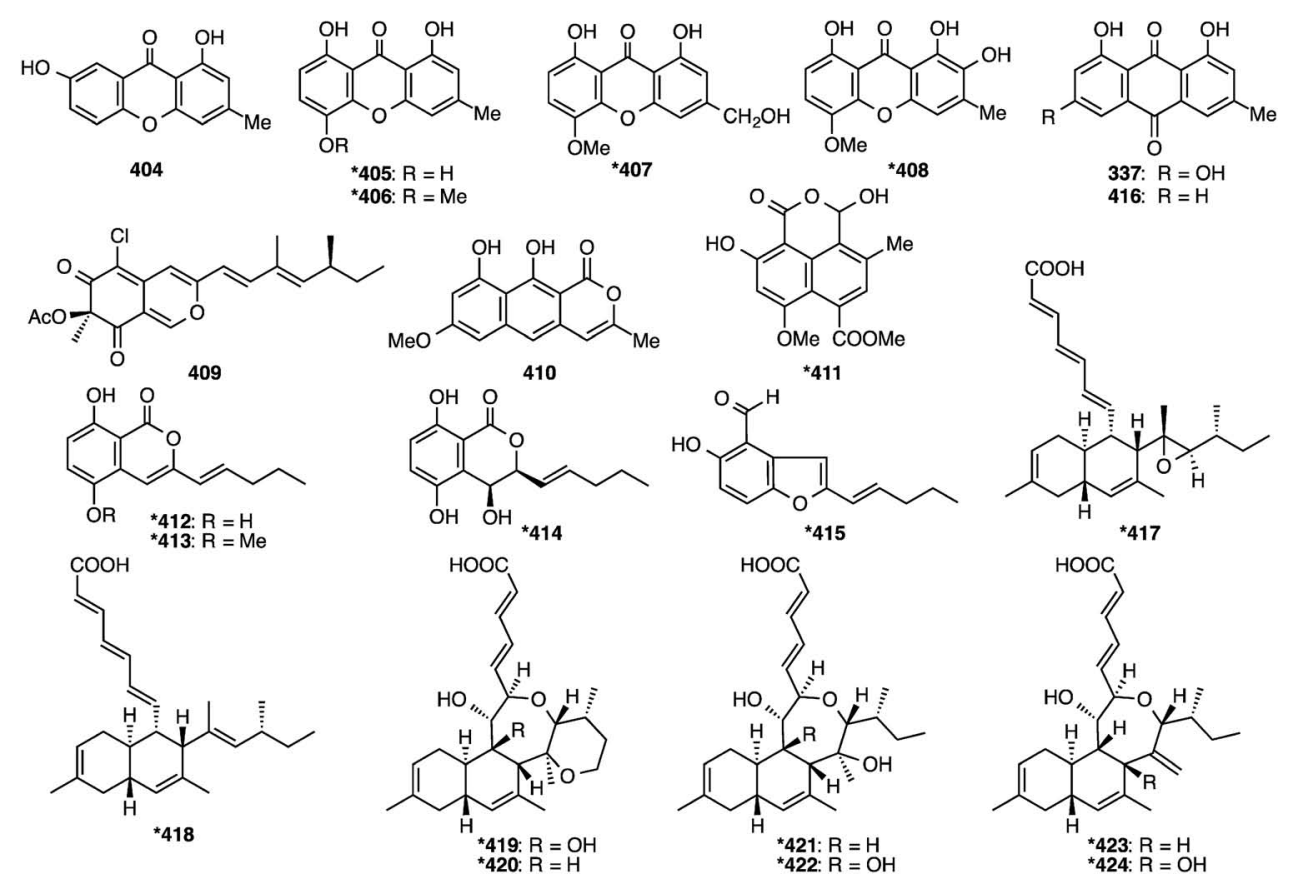

Fig. 45. Metabolites 404-424 of Cultured Mycobionts of Pyrenula spp. Asterisks indicate new compounds.<smiles>CC(=O)C1=C(O)C=C2Oc3c(c(O)c(C)c(O)c3C(C)=O)CC2(N)C1=O</smiles><smiles>COc1cc2c(c(O)c1O)C(=O)c1cnc(C)cc1C2=O</smiles><smiles></smiles><smiles>COc1cc(C)c2c3c(C(C)(C)C(C)O)c(O)c(oc3=O)c2c1C</smiles>

*428<smiles>COc1cc2c(c(O)c1C)C(=O)C1=C(C=C([N+](=O)[O-])OC1OC)C2=O</smiles>

*426<smiles>CC(C)C1(C)Oc2c(O)c3c(=O)oc(=O)c2c2c([N+](=O)[O-])cc(O)c(c32)C1(C)C</smiles>

Fig. 46. Metabolites $\mathbf{3 3 2}$ and 425-430 of Cultured Mycobionts of Haematomma sp. and Trypethelium sp. Asterisks indicate new compounds.

$(+)$-sclerodin (430) とともに得た。 ${ }^{127)} 1,2-$ Naphthoquinone-type の代謝物は培養地衣菌から単 離された例はあるが，428や 430 のよな phenalenone 化合物が培養地衣菌から単離されたのは最初 である（Fig. 46）.

Sarcographa tricosa の培養地衣菌からは, 新規セ スキテルペン 3-epi-petasol (431), dihydropetasol (432), sarcographol（433）を既知セスキテルペン 434-439 と ergosterol peroxide（440）とともに得 た. ${ }^{128)}$ また未同定の Dorygma sp.の培養地衣菌か らは新規セスキテルペン 441-446 と既知化合物 447 を単離した（Fig. 47). ${ }^{129)}$ Eremophilane 型や angu- lar triquinane 骨格のセスキテルペンを培養地衣菌 から単離した最初の報告である。Pseudopyrenula subnudataの培養地衣菌からは新規ポリケチド 448-453 を得た。これらは菌代謝物 versiol の関連 化合物である。この型のへプタケチドを培養地衣菌 から得た最初の例である. ${ }^{130)}$

\section{4-2. 地衣菌代謝物の生合成における炭素骨格の} 起源地衣類が生産する地衣成分の生合成経路は 菌類の代謝物との比較から推定されているが，実際 に投与実験や酵素実験により検討した例はごく限ら れている.これは地衣類の成長が極めて遅いこと, 個体も小さく実験材料として十分な量を得ることが 

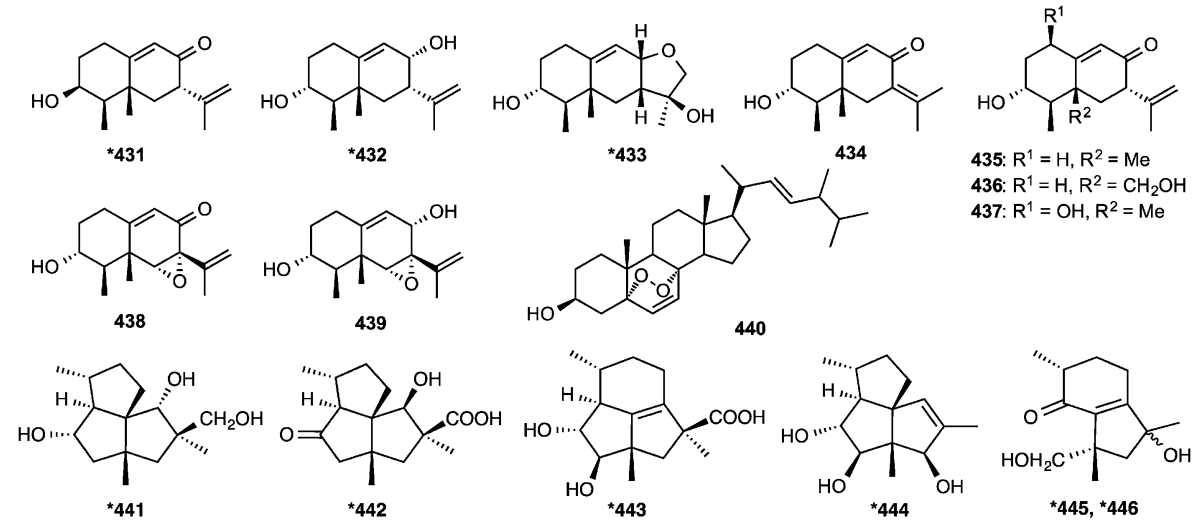

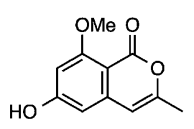

447

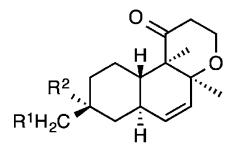

*448: $\mathrm{R}^{1}=\mathrm{R}^{2}=\mathrm{H}$ *449: $\mathrm{R}^{1}=\mathrm{H}, \mathrm{R}^{2}=\mathrm{OH}$ *450: $\mathrm{R}^{1}=\mathrm{OH}, \mathrm{R}^{2}=\mathrm{H}$

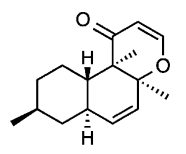

*451

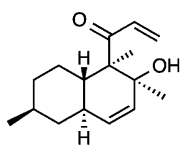

*452

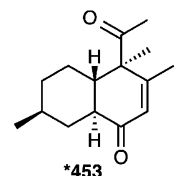

*453

Fig. 47. Metabolites 431-453 of Cultured Mycobionts of Sarcographa tricosa, Dorygma sp. and Pseudopyrenula subnudata Asterisks indicate new compounds.

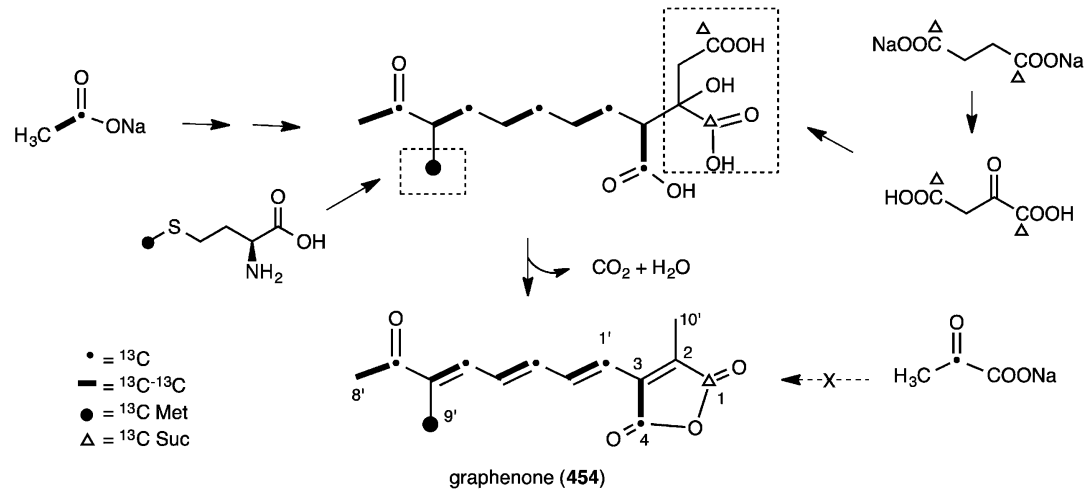

Fig. 48. Biosynthetic Origin of Graphenone (454)

困難なことなどが，生合成実験の障害となっている ためである。しかし，地衣菌培養では長期間無菌条 件で培養が可能であり，比較的多くの細胞を扱える ことから，生合成実験には適した実験系であるとい える，そこで，地衣体の典型的な地衣成分ではなく 異常な代謝物であるが，炭素骨格の特徽的な化合物 を産生する地衣菌に関して, ${ }^{13} \mathrm{C}$ 標識化合物の投与 実験を行い，それら代謝物の炭素骨格の起源を明ら かにした。 そのうち，2 例について簡単に述べる.

Graphenone の炭素骨格の起源

Graphenone（454）は，宮川らにより Graphis scriptaの培養地衣菌から単離構造決定されてお り, ${ }^{101)}$ Graphis handelii の培養地衣菌も生産するこ とが確認された。そこで, ${ }^{13} \mathrm{C}$ 標識体を G. handelii
の培養地衣菌に投与すると, graphenone の C-4C-3, C-1'-C-8'の $\mathrm{C}_{10}$ ユニットには酶酸が取り込ま れ，C-9'は $S$-アデノシルメチオニンのメチル基由 来であることが明らかとなった。しかし， pyruvate や glycerol は取り込まれず, succinateの標識が graphenone のC-1 に取り込まれたことから，C-1， $\mathrm{C}-2, \mathrm{C}-10^{\prime}$ の $\mathrm{C}_{3}$ ユニットは $\mathrm{C}_{3}$ の前駆体が直接取り 込まれるのではなく, succinateなど $\mathrm{C}_{4}$ 体に由来す ることが明らかとなった (Fig. 48).131)

Lecanopyrone 生合成におけるへプタケチド鎖の 閉環様式

Lecanopyrone（401） と類似した骨格を持つ simonyellin は，地衣 Simonyella variegata STEINER から単離された化合物で，ヘプタケチドの環化に 


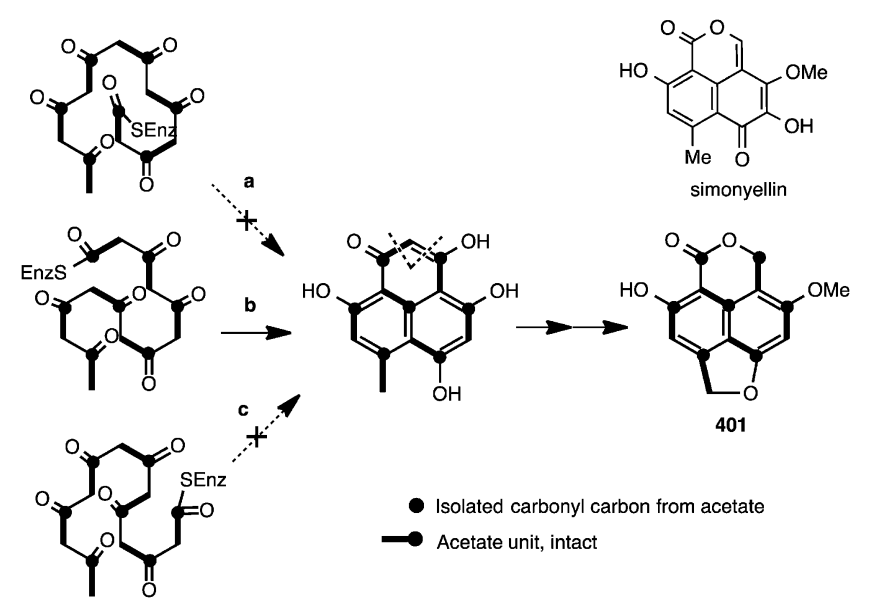

Fig. 49. Folding of Heptaketide Chain in the Biosynthesis of Lecanopyrone (401)

よって生成した phenalenone 中間体が，酸化を受 け，ついで炭素原子 1 個を失い，最終的に脱水する

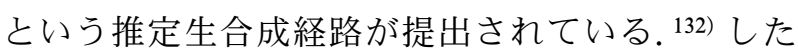
がって, lecanopyrone も同様に, ヘプタケチドが $\mathbf{a}, \mathbf{b}, \mathbf{c}$ のいずれかの閉環様式により生じる phenalenone 骨格を経て生合成されると考えられ る。そこで， ${ }^{13} \mathrm{C}$ 標識の酢酸を Lecanora leprosaの 培養地衣菌への投与実験を行い, 401 は様式 bでへ プタケチド閉環後, 酸化的な開環の過程を経て生合 成されることが明らかとなった（Fig. 49). ${ }^{119)}$

4-3. 培養地衣菌の代謝物の地衣藻成長阻害活性 地衣成分には抗酸化活性や微生物, 高等植物, 藻 への成長阻害活性があることが報告されている。こ のような微生物に対するトキシン，あるいは光や酸 素のストレスに対する紫外線吸収物質や抗酸化剂と しての機能は, 地衣の生存にとって重要な生理的意 義, 生体の化学防御の役割を果たしている可能性が 考えられる。しかし，地衣菌は単離培養条件下で は，天然の地衣体の地衣成分とは骨格の異なる新規 化合物を生産する例が数多く見い出された.このこ とから，これら培養地衣菌の代謝物の生理的な意義 を検討することは，地衣菌の共生状態における役割 及び共生が物質生産に及ぼす影響を考える上で重要 である.

Ahmadjian は地衣成分の生合成における共生藻 の役割について興味深い仮説を提出している. ${ }^{133)}$ 一般的なデプシドやデプシドンなどの地衣成分は orsellinic acid を経由した経路で生合成されると考 えられるのに対し，菌類では orsellinic acid から脱
炭酸した orcinol を前駆体として生合成されたと考 えられる代謝物が多い。このことから地衣菌は本来 菌類と同様の化合物を生合成する能力を持っている が，それらには毒性があるために地衣体では共生藻 がデカルボキシラーゼ阻害物質を産生し，地衣菌の orsellinic acid のエステル化を優先しているため, デプシドやデプシドンが蓄積するとする説である. 地衣菌培養から得たジフェニルエーテル類やジベン ゾフラン類は脱炭酸し，カルボキシ基を持たないも のであったという点では Ahmadjian の説に符合し ており，非常に興味深い結果と言える.

地衣菌培養の代謝物が, 地衣成分とは異なり菌代 謝物に近いものであったことから，本来地衣菌は菌 類と同様の代謝能を持つが，共生状態のときには藻 類に不都合な化合物の生産が抑制されているとの考 えに基づき, 種々の地衣菌代謝物の共生藻の成長に 対する影響を検討した。 アントラキノン 337, 338, 340, キサントン 391-396, 404-406, 408, グラフィ スラクトン類 $343,344,345$, クロモン 354,356 , イソクマリン 361, 412, ジベンゾフラン 332, 390, 397, 400, カルボン酸類 357,359 及び graphenone (451), graphisquinone（370）を含む BBM 培地で 共生藻 Trebouxia erici を振とう培養した。培養地 衣菌でのみ生産される異常な代謝物のうち 343 , 361, 390, 397, 400, 412 は共生藻の成長を約 40-60\% に抑制した。この結果より，培養地衣菌の代謝物の うちあるものは共生藻の成長阻害物質であるため, 共生体ではその生合成能の発現は抑制されている可 能性が示唆された。しかし地衣菌の代謝物でも抑制 
しないものもあり，また地衣成分 emodin（337）や キサントン 391-393 は成長を阻害した。地衣類は地 衣菌が共生藻と共生しているが，その組み合わせは 任意のものはなく，自然界においては特定の組み合 わせでのみ共生する．地衣菌の代謝物が共生藻の種 間の選別や，共生状態における共生藻の成長の制御 に関与している可能性も考えられる. ${ }^{134)}$

\section{4-4. 地衣菌単離培養による物質生産の課題と可} 能性 地球上に広く分布している地衣類はデプシ ド等の地衣成分を産生することで知られている．地 衣成分の構造研究は，わが国における薬学，天然物 化学の歴史に大きな位置を占めてきたが，地衣成分 は地衣類に特徵的であるゆえに構造上の多様性がそ しいと言える。しかし，地衣類から地衣菌を単離培 養することにより種々の二次代謝物の生産が可能で ある。われわれが培養地衣菌から単離した代謝物の 多くは新規化合物で, 構造的には従来の地衣成分と は全く異なり，菌代謝物に類似した多様な化合物が 得られた。この理由として，「菌の進化過程で共生 という生活形態を獲得した地衣菌では，共生藻に とつて好ましくない二次代謝物の生合成の発現は抑 制されるようになった。しかし，単離培養条件では 共生を脱したことにより，内在する休眠二次代謝関 連遺伝子が発現してきた」ためと考えられる。した がって，地衣菌の単離培養により潜在的な二次代謝 関連遺伝子を発現させることができれば，地衣類は 新規生物活性物質の供給源となる可能性がある。し かし，二次代謝物を生産しない培養地衣菌株も多 く，いかにしてこれら地衣菌の休眠遺伝子を高発現 させて, 有用な二次代謝物の生産を実現させるかが 課題である. 最近のゲノム解析により，糸状菌に は，これまで単離同定された二次代謝物から予測さ れる数より遥かに多くの生合成遺伝子が存在してお り，その多くが休眠遺伝子と考えられている，その ため，エピジェネティック制御により休眠遺伝子の 発現を活性化し，新規有用物質の探索につなげる研

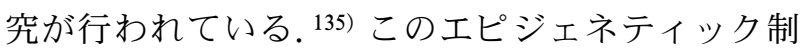
御を地衣菌培養に効果的に応用できれば，新たな物 質生産につながることが期待できる。しかし，現在 までのところ，筆者らの実験から良好な結果は得ら れていない。地衣体と同様に地衣菌も生育が遅いこ とが障害で，今後は最適な培養条件の検討と，転写 活性を適切に制御する添加薬物の選択が課題であ
る，有用な代謝物が発見できれば，分子生物学的手 法による微生物異種発現系を用いた生合成系の構築 への展開が望まれる。.また最近，多くの地衣菌及び 藻類の遺伝子の発現が地衣化により抑制されること が報告され，遺伝子の発現の抑制が地衣化のプロセ スで重要な役割を果たす可能性が示唆されている が，どのような遺伝子が関与しているかは明らかに されていない。今後, 地衣菌, 共生藻のゲノムや遺 伝子発現の情報の解明は，物質生産のみならず共生 生物学にとって重要な課題であろう.

\section{5. おわりに}

天然薬用資源は，創薬の歴史において数多くの薬 の種を供給し, 天然物化学は薬学の中で重要な位置 を占めてきた. しかし，近年，天然物化学分野の研 究内容, 方法論は大きく変化している，筆者が天然 物化学の研究を開始した当時は, 研究室に HPLC は 1 台もなく, NMR も $60 \mathrm{MHz}$ が主流で，二次代 謝物の生合成研究も放射性標識化合物を用いた投与 実験を行っていた。 その後, 分離技術や機器分析の 飛躍的な進歩により，構造解析技術も大きく変化 し，また生合成研究も，酵素レベルの研究さらには 網羅的な遺伝子解析により二次代謝の制御の原理を 解明しようとする段階に移行している．筆者は，二 次代謝物の生合成研究を意識しつつも，二次代謝物 の構造解析を中心に研究を行ってきた。二次代謝物 の多様性を知ることは，生合成研究において重要な 情報，試料を提供し，また，新たな生物活性物質の 発見にもつながると期待したからである. 天然有機 化合物は，人知を超えた構造の新規性，多様性があ り，また生命活動と深く係わっている．今後も天然 物化学の研究が, 複数の異なる分野との緊密な連携 をとりながら，新たな創薬研究へと展開し，また生 命活動のダイナミズムに迫るために更なる発展をし ていくことを期待している.

謝辞神戸薬科大学在職中, 終始多大なるご指 導，ご支援を頂きました永倉直敬元学長に深く感謝 申し上げます。また，これまで研究に携わってこら れたのは，故井上博之教授，故 M. H. Zenk 教授の 薰陶の賜物と心より感謝するとともに，ご冥福をお 祈り致します。また在職中の研究成果は, 薬化学研 究室の竹仲由希子准教授, 西村克己講師, 旧研究室 員の伊藤篤子元講師，島田厚子元助手，神前祥子元 
助手及び多くの大学院生, 学部学生の努力によるも のであります。ここに厚く御礼を申し上げます。さ らに，種々のご協力を頂きました国内外の大学や企 業の多くの共同研究者に深甚の謝意を表します。ま た本研究の一部は, 文部科学省科学研究費, 神戸薬 科大学共同研究費の支援により遂行したものです.

利益相反＼cjkstart開示すべき利益相反はない.

\section{REFERENCES}

1) Inouye H., Uesato S., Prog. Chem. Org. Nat. Prod., 50, 171-236 (1986).

2) Battersby A. R., Pure Appl. Chem., 14, 117136 (1967).

3) Battersby A. R., Westcoltt N. D., Glüsenkamp K.-H., Tietze L.-F., Chem. Ber., 114, 3439-3447 (1981).

4) Inoue K., Takeda Y., Tanahashi T., Inouye H., Chem. Pharm. Bull., 29, 981-990 (1981).

5) Yamamoto H., Katano N., Ooi A., Inoue K., Phytochemistry, 53, 7-12 (2000).

6) Battersby A. R., Burnett A. R., Parsons, P. G., J. Chem. Soc. C, 1187-1192 (1969).

7) Battersby A. R., Parry R. J., Chem. Commun., 901-902 (1971).

8) Nagakura N., Höfle G., Zenk M. H., J. Chem. Soc. Chem. Commun., 896-898 (1978).

9) Nagakura N., Höfle G., Coggiola D., Zenk M. H., Planta Med., 34, 381-389 (1978).

10) Itoh A., Tanahashi T., Nagakura N., Chem. Pharm. Bull., 37, 1137-1139 (1989).

11) Itoh A., Tanahashi T., Nagakura N., Phytochemistry, 30, 3117-3123 (1991).

12) Nagakura N., Itoh A., Tanahashi T., Phytochemistry, 32, 761-765 (1993).

13) Itoh A., Tanahashi T., Nagakura N., Nayeshiro H., Phytochemistry, 36, 383-387 (1994) .

14) Itoh A., Baba Y., Tanahashi T., Nagakura N., Phytochemistry, 59, 91-97 (2002).

15) Itoh A., Ikuta Y., Baba Y., Tanahashi T., Nagakura N., Phytochemistry, 52, 1169-1176 (1999) .

16) Höfle G., Nagakura N., Zenk M. H., Chem. Ber., 113, 566-576 (1980).

17) Itoh A., Tanahashi T., Nagakura N., Chem.
Pharm. Bull., 42, 2208-2210 (1994).

18) Itoh A., Tanahashi T., Nagakura N., J. Nat. Prod., 58, 1228-1239 (1995).

19) Itoh A., Tanahashi T., Nagakura N., Phytochemistry, 41, 651-656 (1996).

20) Itoh A., Tanahashi T., Nagakura N., Phytochemistry, 46, 1225-1229 (1997).

21) Itoh A., Tanahashi T., Nagakura N., Heterocycles, 48, 499-505 (1998).

22) Itoh A., Tanahashi T., Tabata M., Shikata M., Kakite M., Nagai M., Nagakura N., Phytochemistry, 56, 623-630 (2001).

23) Itoh A., Tanahashi T., Nagakura N., Phytochemistry, 31, 1037-1040 (1992).

24) Itoh A., Tanahashi T., Nagakura N., Phytochemistry, 33, 161-164 (1993).

25) Tanahashi T., Kobayashi C., Itoh A., Nagakura N., Inoue K., Kuwajima H., Wu H.-X., Chem. Pharm. Bull., 48, 415-419 (2000).

26) Itoh A., Tanahashi T., Ikejima S. (née Sato), Inoue M., Nagakura N., Inoue K., Kuwajima H., Wu H.-X., J. Nat. Prod., 63, 95-98 (2000) .

27) Wiegrebe W., Kramer W. J., Shamma M., J. Nat. Prod., 47, 397-408 (1984).

28) Itoh A., Ikuta Y., Tanahashi T., Nagakura N., J. Nat. Prod., 63, 723-725 (2000) .

29) De-Ekunamkul W., Ounaroon A., Tanahashi T., Kutchan T. M., Zenk M. H., Phytochemistry, 45, 477-484 (1997).

30) De-Eknamkul W., Suttipanta N., Kutchan T. M., Phytochemistry, 55, 177-181 (2000).

31) Nomura T., Quesada A. L., Kutchan T. M., $J$. Biol. Chem., 283, 34650-34659 (2008).

32) Nomura T., Kutchan T. M., J. Biol. Chem., 285, 7722-7738 (2010).

33) De-Eknamkul W., Zenk M. H., Phytochemistry, 31, 813-821 (1992).

34) Jain S., Chaudhary P. N., Gawade V. B., Scientific World, 10, 2304-2328 (2012).

35) Pakrashi S. C., Mukhopadhyay R., Sinha R. R., Ghosh Dastidar P. P., Achari B., Ali E., Indian J. Chem., 24B, 19-28 (1985).

36) Itoh A., Tanahashi T., Nagakura N., J. Nat. Prod., 59, 535-538 (1996).

37) Itoh A., Tanahashi T., Nagakura N., Nishi T., Phytochemistry, 62, 359-369 (2003).

38) Itoh A., Fujii K., Tomatsu S., Takao C., 
Tanahashi T., Nagakura N., Chen C.-C., $J$. Nat. Prod., 66, 1212-1216 (2003).

39) Tanahashi T., Takenaka Y., Kobayashi C., Watsuji J., Nagakura N., Chen C.-C., Natural Medicines, 51, 556 (1997).

40) Itoh A., Oya N., Kawaguchi E., Nishio S., Tanaka Y., Kawachi E., Nishi T., Tanahashi T., J. Nat. Prod., 68, 1434-1436 (2005).

41) Itoh A., Tanaka Y., Nagakura N., Akita T., Nishi T., Tanahashi T., Phytochemistry, 69, 1208-1214 (2008).

42) Tietze L. F., Bärtels C., Liebigs Ann. Chem., 155-160 (1991).

43) Itoh A., Kumashiro T., Yamaguchi M., Nagakura N., Mizushina Y., Nishi T., Tanahashi T., J. Nat. Prod., 68, 848-852 (2005) .

44) Jensen S. R., Franzyk H., Wallander E., Phytochemistry, 60, 213-231 (2002).

45) Tanahashi T., Watanabe H., Itoh A., Nagakura N., Inoue K., Ono M., Fujita T., Chen C.-C., Phytochemistry, 31, 2143-2145 (1992).

46) Tanahashi T., Watanabe H., Itoh A., Nagakura N., Inoue K., Ono M., Fujita T., Morita M., Chen C.-C., Phytochemistry, 32, 133-136 (1993).

47) Tanahashi T., Shimada A., Nagakura N., Inoue K., Kuwajima H., Takaishi K., Chen C.-C., Phytochemistry, 33, 397-400 (1993) .

48) Tanahashi T., Shimada A., Nagakura N., Inoue K., Kuwajima H., Takaishi K., Chen C.-C., He Z.-D., Yang C.-R., Chem. Pharm. Bull., 41, 1649-1651 (1993).

49) Tanahashi T., Parida, Takenaka Y., Nagakura N., Inoue K., Kuwajima H., Chen C.-C., Phytochemistry, 49, 1333-1337 (1998) .

50) Takenaka Y., Okamoto A., Hirose H., Tanahashi T., Abstracts of papers, the 136th Annual Meeting of the Pharmaceutical Society of Japan, Yokohama, March 2016, No.2, p. 216.

51) Takenaka Y., Tanahashi T., Shintaku M., Sakai T., Nagakura N., Parida, Phytochemistry, 55, 275-284 (2000).

52) Takenaka Y., Okazaki N., Tanahashi T., Nagakura N., Nishi T., Phytochemistry, 59, 779-787 (2002).

53) Tanahashi T., Sakai T., Takenaka Y., Nagakura N., Chen C.-C., Chem. Pharm. Bull., 47, 1582-1586 (1999).
54) Tanahashi T., Shimada A., Nagakura N., Nayeshiro H., Planta Med., 58, 552-555 (1992).

55) Tanahashi T., Takenaka Y., Nagakura N., Phytochemistry, 41, 1341-1345 (1996).

56) Tanahashi T., Takenaka Y., Akimoto M., Okuda A., Kusunoki Y., Suekawa C., Nagakura N., Chem. Pharm. Bull., 45, 367372 (1997).

57) Takenaka Y., Tanahashi T., Nagakura N., Phytochemistry, 48, 317-322 (1998).

58) Tanahashi T., Takenaka Y., Nagakura N., $J$. Nat. Prod., 60, 514-518 (1997).

59) Takenaka Y., Tanahashi T., Nagakura N., Chem. Pharm. Bull., 46, 1776-1780 (1998).

60) Tanahashi T., Shimada A., Nagakura N., Inoue K., Ono M., Fujita T., Chen C.-C., Chem. Pharm. Bull., 43, 729-733 (1995).

61) Tanahashi T., Shimada A., Kai M., Nagakura N., Inoue K., Chen C.-C., J. Nat. Prod., 59, 798-800 (1996).

62) Kamikawa T., Inoue K., Kubota T., Woods M. C., Tetrahedron, 26, 4561-4587 (1970) .

63) Inoue K., Tanahashi T., Inouye H., Phytochemistry, 24, 1299-1303 (1985) .

64) Tanahashi T., Nagakura N., Kuwajima H., Takaishi K., Inoue K., Inouye H., Phytochemistry, 28, 1413-1415 (1989).

65) Inoue K., Fujita T., Inouye H., Kuwajima H., Takaishi K., Tanahashi T., Nagakura N., Asaka Y., Kamikawa T., Shingu T., Phytochemistry, 30, 1191-1201 (1991).

66) Tanahashi T., Nagakura N., Inoue K., Inouye H., Tetrahedron Lett., 29, 1793-1796 (1988).

67) Tanahashi T., Takenaka Y., Nagakura N., Nishi T., J. Nat. Prod., 62, 1311-1315 (1999).

68) Tanahashi T., Takenaka Y., Nagakura N., Nishi T., Chem. Pharm. Bull., 48, 1200-1204 (2000).

69) Takenaka Y., Tanahashi T., Taguchi H., Nagakura N., Nishi T., Chem. Pharm. Bull., 50, 384-389 (2002).

70) Tanahashi T., Nagakura N., Inoue K., Inouye H., Shingu T., Chem. Pharm. Bull., 35, 50325035 (1987).

71) Tanahashi T., Takenaka Y., Okazaki N., Koge M., Nagakura N., Nishi T., Phytochemistry, 70, 2072-2077 (2009).

72) Shen Y.-C., Chen C.-H., J. Nat. Prod., 52, 
1060-1070 (1989).

73) Gariboldi P., Jommi G., Verotta L., Phytochemistry, 25, 865-869 (1986).

74) Inoue K., Nishioka T., Tanahashi T., Inouye H., Phytochemistry, 21, 2305-2311 (1982) .

75) Kuwajima H., Tanahashi T., Inoue K., Inouye H., Chem. Pharm. Bull., 47, 1634-1637 (1999).

76) Alagna F., Geu-Flores F., Kries H., Panara F., Baldoni L., O'Connor S. E., Osbourn A., J. Biol. Chem., 291, 5542-5554 (2016).

77) Takao N., Kamigauchi M., Okada M., Helv. Chim. Acta, 66, 473-484 (1983).

78) Kutchan T. M., Dittrich H., Bracher D., Zenk M. H., Tetrahedron, 47, 5945-5954 (1991) .

79) Tanahashi T., Zenk M. H., Tetrahedron Lett., 29, 5625-5628 (1988).

80) Tanahashi T., Zenk M. H., Phytochemistry, 29, 1113-1122 (1990).

81) Schumacher H.-M., Gundlach H., Fiedler F., Zenk M. H., Plant Cell Rep., 6, 410-413 (1987).

82) Tanahashi T., Zenk M. H., J. Nat. Prod., 53, 579-586 (1990).

83) De-Eknamkul W., Tanahashi T., Zenk M. H., Phytochemistry, 31, 2713-2717 (1992) .

84) Kammerer L., De-Eknamkul W., Zenk M. H., Phytochemistry, 36, 1409-1416 (1994).

85) Schumacher H.-M., Zenk M. H., Plant Cell. Rep., 7, 43-46 (1988).

86) Takemura T., Ikezawa N., Iwasa K., Sato F., Phytochemistry, 91, 100-108 (2013).

87) Buck K. T., "The Alkaloids: Chemistry and Pharmacology," Vol. 30, Chap. 1, ed. by Brossi A., Academic Press, San Diego, 1987, pp. 1-222.

88) Tanahashi T., Su Y., Nagakura N., Nayeshiro H., Chem. Pharm. Bull., 48, 370-373 (2000).

89) Nakaoji K., Nayeshiro H., Tanahashi T., Su Y., Nagakura N., Planta Med., 63, 425-428 (1997).

90) Nakaoji K., Nayeshiro H., Tanahashi T., Biol. Pharm. Bull., 20, 586-588 (1997).

91) Sugimoto Y., Furutani S., Itoh A., Tanahashi T., Nakajima H., Oshiro H., Sun S., Yamada J., Phytomedicine, 15, 1117-1124 (2008) .

92) Itoh A., Saitoh T., Tani K., Uchigaki M., Sugimoto Y., Yamada J., Nakajima H., Ohshiro H., Sun S., Tanahashi T., Chem.
Pharm. Bull., 59, 947-951 (2011).

93) Nishimura K., Horii S., Tanahashi T., Sugimoto Y., Yamada J., Chem. Pharm. Bull., 61, 59-68 (2013).

94) Sugimoto Y., Furutani S., Nishimura K., Itoh A., Tanahashi T., Nakajima H., Oshiro H., Sun S., Yamada J., Eur. J. Pharmacol., 634, 62-67 (2010).

95) Sugimoto Y., Nishimura K., Itoh A., Tanahashi T., Nakajima H., Oshiro H., Sun S., Toda T., Yamada J., J. Pharm. Pharmacol., 67, 1716-1722 (2015).

96) Asahina Y., Prog. Chem. Org. Nat. Prod., 8, 207-244 (1951).

97) Huneck S., Prog. Chem. Org. Nat. Prod., 81, 1-313 (2001).

98) Yamamoto Y., Chemical Regulation of Plants, 35, 169-179 (2000).

99) Shukla V., Joshi G. P. Rawat M. S. M., Phytochem. Rev., 9, 303-314 (2010) .

100) Ahmadjian V., "The Lichen Symbiosis," John Wiley and Sons, Inc., New York, 1993.

101) Miyagawa H., Hamada N., Sato M., Ueno T., Phytochemistry, 36, 1319-1322 (1994).

102) Takenaka Y., Tanahashi T., Nagakura N., Hamada N., Lichenology, 1, 7-10 (2002).

103) Tanahashi T., Kuroishi M., Kuwahara A., Nagakura N., Hamada N., Chem. Pharm. Bull., 45, 1183-1185 (1997).

104) Tanahashi T., Takenaka Y., Nagakura N., Hamada N., Phytochemistry, 62, 71-75 (2003).

105) Hamada N., Tanahashi T., Miyagawa H., Miyawaki H., Symbiosis, 31, 23-33 (2001).

106) Höller U., König G. M., Wright A. D., Eur. J. Org. Chem., 2949-2955 (1999).

107) Zhang H.-W., Huang W.-Y., Song Y.-C., Chen J.-R., Tan R.-X., Helv. Chim. Acta, 88, 2861-2864 (2005).

108) Takenaka Y., Tanahashi T., Nagakura N., Hamada N., Heterocycles, 53, 1589-1593 (2000) .

109) Takenaka Y., Hamada N., Tanahashi T., Heterocycles, 89, 2760-2770 (2014).

110) Takenaka Y., Tanahashi T., Nagakura N., Hamada N., Natural Medicines, 57, 34 (2003) .

111) Tanahashi T., Takenaka Y., Nagakura N., Hamada N., Miyawaki H., Heterocycles, 53, 
723-728 (2000).

112) Takenaka Y., Tanahashi T., Nagakura N., Hamada N., Chem. Pharm. Bull., 51, 794-797 (2003).

113) Takenaka Y., Hamada N., Tanahashi T., Heterocycles, 83, 2157-2164 (2011).

114) Takenaka Y., Morimoto, N., Hamada N., Tanahashi T., Phytochemistry, 72, 1431-1435 (2011).

115) Le D. H., Takenaka Y., Hamada N., Miyawaki H., Tanahashi T., Chem. Pharm. Bull., 61, 358-362 (2013).

116) Takenaka Y., Taguchi S., Le D. H., Hamada N., Tanahashi T., Heterocycles, 87, 26512657 (2013).

117) Takenaka Y., Hamada N., Tanahashi T., Phytochemistry, 66, 665-668 (2005).

118) Tanahashi T., Takenaka Y., Nagakura N., Hamada N., Phytochemistry, 58, 1129-1134 (2001).

119) Takenaka Y., Hamada N., Tanahashi T., Z. Naturforsch., 65c, 637-641 (2010).

120) Takenaka Y., Hamada N., Tanahashi T., Z. Naturforsch., 60b, 1324-1326 (2005).

121) Tanahashi T., Takenaka Y., Ikuta Y., Tani K., Nagakura N., Hamada N., Phytochemistry, 52, 401-405 (1999).

122) Takenaka Y., Tanahashi T., Nagakura N., Hamada N., Z. Naturforsch., 55c, 910-914 (2000) .

123) Takenaka Y., Nagakura N., Hamada N., Tanahashi T., Heterocycles, 81, 1931-1935 (2010).

124) Takenaka Y., Tanahashi T., Nagakura N.,
Itoh A., Hamada N., Phytochemistry, 65, 3119-3123 (2004).

125） Le D. H., Takenaka Y., Hamada N., Mizushina Y., Tanahashi T., J. Nat. Prod., 77, 14041412 (2014).

126) Takenaka Y., Mizushina Y., Hamada N., Tanahashi T., Heterocycles, 94, 1728-1735 (2017)

127) Takenaka Y., Naito Y., Le D. H., Hamada N., Tanahashi T., Heterocycles, 87, 18971902 (2013).

128) Le D. H., Takenaka Y., Hamada N., Tanahashi T., Phytochemistry, 91, 242-248 (2013).

129) Tanahashi T., Takenaka Y., Abstract Book, the 63rd International Congress and Annual Meeting of the Society for Medicinal Plant and Natural Product Reserch, Budapest, Augast 2015, p. 147.

130) Takenaka Y., Tanahashi T., Abstract Book, the 63rd International Congress and Annual Meeting of the Society for Medicinal Plant and Natural Product Reserch, Budapest, Augast 2015, p. 332.

131) Takenaka Y., Hamada N., Tanahashi T., $Z$. Naturforsch., 63c, 565-568 (2008).

132) Elix J. A., Feige G. B., Lumbsch H. T., Mies B., Wardlaw J. H., Willis A. C., Aust. J. Chem., 48, 2035-2039 (1995).

133) Curberson C. F., Ahmadjian V., Mycologia, 72, 90-109 (1980).

134) Takenaka Y., Tanahashi T., Hamada N., Lichenology, 7, 153-158 (2008).

135) Cichewiz R. H., Nat. Prod. Rep., 27, 11-22 (2010) 